\author{
Monograph \\ urn:1sid:zoobank.org:pub:F67AE00B-28CF-48AF-89D6-31251B22BB7C
}

\title{
Daddy-long-leg giants: revision of the spider genus Artema Walckenaer, 1837 (Araneae, Pholcidae)
}

\author{
Shlomi AHARON ${ }^{1}$, Bernhard A. HUBER ${ }^{2}$ \& Efrat GAVISH-REGEV ${ }^{3, *}$ \\ ${ }^{1}$ Blaustein Institutes for Desert Research, Ben-Gurion University of the Negev, \\ Sede Boqer Campus, Midreshet Ben-Gurion, Israel. \\ ${ }^{2}$ Alexander Koenig Research Museum of Zoology, Adenauerallee 160, 53113 Bonn, Germany. \\ ${ }^{3}$ The Arachnid National Natural History Collection, The Hebrew University of Jerusalem, \\ Edmond J. Safra Campus, Givat Ram, Jerusalem, Israel. \\ *Corresponding author: efrat.gavish-regev@mail.huji.ac.il \\ ${ }^{1}$ Email: shlomi.aharon@gmail.com \\ 2Email: b.huber@zfmk.de \\ ${ }^{1}$ urn:lsid:zoobank.org:author:FB5EEA73-DD16-440C-B611-07F1C0C1300B
${ }^{2}$ urn:Isid:zoobank.org:author:33607F65-19BF-4DC9-94FD-4BB88CED455F
${ }^{3}$ urn:Isid:zoobank.org:author:FC073F19-2202-4C89-8B43-CEA4CC5E2D50
}

\begin{abstract}
This is the first revision of Artema Walckenaer, 1837, a genus consisting of large and phylogenetically interesting species. Even though Artema is not species-rich (now eight nominal species), it has suffered from poor descriptions and synonymies. Our main goal was to gather all available material and to clarify species limits. Four species are easily distinguished from other congeners: Artema atlanta Walckenaer, 1837, the type species; A. kochi Kulczyński, 1901 (revalidated); A. bunkpurugu Huber \& Kwapong, 2013; and $A$. nephilit sp. nov. All other species are problematic for varying reasons: species limits are unclear between A. doriae Thorell, 1881 and A. transcaspica Spassky, 1934; A. magna Roewer, 1960 and A. ziaretana (Roewer, 1960) are problematic because they are based on female and juvenile types respectively and little new material is available. The material available to us suggests the existence of a few further species; however, they are not formally described, either because of small sample sizes (Artema sp. a and $A . \mathrm{sp} . \mathrm{b}$ are represented by only one specimen each) or because of unclear species limits (between Artema sp. c, A. transcaspica and A. doriae).This study is the first serious step towards understanding the genus. Intensive collecting effort is needed in order to fully clarify species limits.
\end{abstract}

Keywords. Key, Middle East, Pholcidae, taxonomy.

Aharon S., Huber B.A. \& Gavish-Regev E. 2017. Daddy-long-leg giants: revision of the spider genus Artema Walckenaer, 1837 (Araneae, Pholcidae). European Journal of Taxonomy 376: 1-57.

https://doi.org/10.5852/ejt.2017.376

\section{Introduction}

The genus Artema Walckenaer, 1837 includes some of the largest pholcid spiders, with most species distributed from northern Africa to the Middle East. These pholcids inhabit dark and sheltered habitats 
such as caves, holes and crevices as as well as man-made habitats like bunkers, buildings and basements (Aharon 2016; Huber \& Kwapong 2013). The genus is widely known due to the widespread synanthropic species Artema atlanta Walckenaer, 1837. However, the systematics of the genus that previously included six species (World Spider Catalog 2017) (now eight) is chaotic and obscure. Most species are impossible to identify from the existing literature, no revision has ever been made of the genus, and illustrations are often of poor quality or not available at all (Thorell 1881; Spassky 1934; Roewer 1960; Tabrizi et al. 2014).

Artema does not only include unusually large species, but it is also phylogenetically interesting. Morphological data suggest that Artema is sister to all other Arteminae (Huber 2016), while molecular data suggest it might even be sister to all other Pholcidae (J. Eberle, A. Valdez-Mondragón, D. Dimitrov, B.A. Huber, unpublished data). The subfamily Arteminae has a worldwide distribution, yet none of its genera is distributed around the world (except for synanthropic species), which suggests that the split leading to Artema may be a very old one.

Most diversity in the genus Artema is concentrated in a region of the world that has seen much political instability recently. As a result, very little material has been added to collections over the last decades and fresh material is difficult to obtain. Our main effort in this revision was thus to gather all available material from collections worldwide, including types, and to clarify species limits as far as possible with this material. Our only serious collecting effort concentrated on Israel, and significant further progress with the taxonomy of the genus will only come with similar efforts across northern Africa and the Middle East.

\section{Material and methods}

This revision is based on material deposited in the following collections: American Museum of Natural History, New York (AMNH); Natural History Museum, London (NHMUK); California Academy of Sciences, San Francisco (CAS); Michael Hadjiconstantis personal collection, Nicosia (CMH); Robert Bosmans personal collection, Ghent (CRB); Sergei Zonstein personal collection, Tel-Aviv (CSZ); Durban Natural Science Museum, Durban (DNSM); Field Museum of Natural History, Chicago (FMNH); Hope Department of Entomology, Oxford (XUM); The National Natural History Collections, The Hebrew University of Jerusalem (HUJ); Museo civico di Storia naturale di Genova (MSNG); Museum of Comparative Zoology, Cambridge, MA(MCZ); Muséum d'Histoire naturelle, Genève (MHNG); Muséum national d'Histoire naturelle, Paris (MNHN); Musée royal de l'Afrique Centrale, Tervuren (MRAC); Museo Zoologico de "la Specola", Universita di Firenze, Florence (MZUF); Naturhistorisches Museum, Basel (NHMB); Naturhistoriska Museet, Göteborg (NHMG); Naturhistorisches Museum Wien, Vienna (NHMW); Forschungsinstitut und Naturmuseum Senckenberg, Frankfurt (SMF); Steinhardt Museum of Natural History at Tel Aviv University (SMNH); Zoologisches Forschungsmuseum Alexander Koenig, Bonn (ZFMK); Zoological Institute, Russian Academy of Sciences, St. Petersburg (ZIN); Museum für Naturkunde, Berlin (ZMB); Zoologisches Institut und Zoologisches Museum, Hamburg (ZMH); Zoological Museum of the Moscow University (ZMMU); Zoological Museum and Collection of Biology of Shiraz University (ZMSU); Zoological Museum, University of Copenhagen, Copenhagen (ZMUC).

Methods and terminology are as in Huber $(2000,2011 \mathrm{a})$. Measurements are in mm unless otherwise noted. Eye measurements are $\pm 5 \mu \mathrm{m}$. Epigyna were cleared using a $10 \% \mathrm{NaOH}$ solution. Cleared epigyna were stained with chlorazol black. Specimens were examined and measured using a Nikon SMZ18 stereo microscope. Digital microscope images were taken using an AxioVision imaging system with AxioCamHR3 digital camera mounted on a ZEISS SteREO Discovery V20 stereo microscope (Zoologisches Forschungsmuseum Alexander Koenig, Bonn). Images were edited using GIMP ver. 2.6.10 and Inkscape ver. 0.48. For SEM photos, specimens were dried in hexamethyldisilazane (HMDS) (Brown 1993), and photographed with a Hitachi S-2460 scanning electron microscope (by BAH). 
SEM data are presented within the descriptions but are not necessarily based on the particular specimen described. Locality coordinates are in round brackets when copied from labels and original publications or when received directly from collectors, in square brackets when originating from some other source (such as online geographical database, Google Earth, etc.). Distribution maps were generated with ArcMap 10.2.2.

\section{Anatomical abbreviations used in text and figures}

$$
\begin{aligned}
\mathrm{a} & =\text { bulbal process a } \\
\mathrm{AEP} & =\text { anterior epigynal projections } \\
\mathrm{ALE} & =\text { anterior lateral eye } \\
\mathrm{ALS} & =\text { anterior lateral spinneret } \\
\mathrm{AME} & =\text { anterior median eye } \\
\mathrm{b} & =\text { bulbal process } \mathrm{b} \\
\mathrm{c} & =\text { bulbal process } \mathrm{c} \\
\mathrm{d} & =\text { bulbal process } \mathrm{d} \\
\mathrm{dp} & =\text { dorsal process on procursus } \\
\mathrm{e} & =\text { bulbal process } \\
\mathrm{em} & =\text { embolus } \\
\mathrm{L} / \mathrm{d} & =\text { length divided by diameter } \\
\mathrm{p} & =\text { procursus } \\
\mathrm{PME} & =\text { posterior median eye } \\
\mathrm{PMS} & =\text { posterior median spinneret } \\
\mathrm{vp} & =\text { ventral pocket on procursus }
\end{aligned}
$$

\section{Results}

\section{Known and new species of Artema}

Class Arachnida Cuvier, 1812

Order Araneae Clerck, 1757

Family Pholcidae C.L. Koch, 1851

Artema Walckenaer, 1837

Artema Walckenaer, 1837: 656; type species: Artema atlanta (by subsequent monotypy).

Coroia González-Sponga, 2005: 102; type species: Coroia magna González-Sponga, 2005; synonymized by Huber et al. 2014: 416.

\section{Diagnosis}

Artema is easily distinguished from other pholcids by its large body and strong legs (body length 5.5$9.5 \mathrm{~mm}$; leg span up to $15 \mathrm{~cm}$; tibia $1 \mathrm{~L} / \mathrm{d}$ : 34-42); also by distinctive pattern on globose and high abdomen (dark dots dorsally, arranged in stripes from dorsal to lateral, sometimes absent; Figs 3-5, 5153); by male pedipalp with its unique bulbal processes and short but massive procursus with proximal dorsal process (dp: Fig. 89) and weakly developed ventral pocket (vp: Fig. 89); by armature of male chelicerae (frontal row of cone-shaped hairs on each side, situated on elevated processes or ridges; Figs 23, 44); and by pair of low to high projections in front of large anterior epigynal plate (AEP: Fig. 15). 


\section{Description}

Male

MeAsuRements. Total body length 5.5-9.5, carapace width 3.0-4.3. Leg 1: 39-61, tibia 1: 6.0-22.2; tibia $1 \mathrm{~L} / \mathrm{d}$ : 34-42. Distance PME-PME 150-220 $\mu \mathrm{m}$, diameter PME 170-230 $\mu \mathrm{m}$, distance PME-ALE 90-140 $\mu \mathrm{m}$, distance AME-AME 30-60 $\mu \mathrm{m}$, diameter AME 180-210 $\mu \mathrm{m}$.

Color. In general variable, even within species. Carapace pale to light brown, sometimes with brown radial marks, with light to dark brown median band (as in Figs 35, 76, 121). Clypeus with wide light brown band. Legs pale yellow to ochre with dark rings on femora subdistally, patellae + tibiae proximally, and tibiae subdistally; tips of femora and tibiae whitish. Abdomen pale gray to light brown, usually with dark dots dorsally, arranged in distinctive stripes from dorsal to lateral side of abdomen (as in Fig. 4); sometimes without any pattern (as in Figs 51-53).

Body. Ocular area slightly elevated. Carapace with median pit and distinct posterior furrow. Clypeus unmodified. Sternum wider than long. Chelicerae with frontal row of $\sim 16-25$ modified (cone-shaped; Figs 34, 68-69) hairs on pair of elevated processes or ridges, variable in shape among species; lateral field of stridulatory ridges on chelicerae present or absent (variable even within species; Figs 31, 70, 118). Abdomen globose and high (as in Fig. 5). Gonopore with 4-7 epiandrous spigots (Fig. 63). Anterior lateral spinnerets with one extremely widened, one long pointed, and six cylindrically shaped spigots each (Figs 26, 28, 74); PMS with two spigots each (Figs 25, 75); PLS without spigots.

PaLPs. Coxa unmodified. Trochanter with short ventral projection (as in Figs 77-79). Femur with short, somewhat pointed retrolateral process proximally (as in Figs 180-182); ventral membranous area proximally bordered on both sides by sclerotized ridges. Patella very short. Procursus with proximal dorsal process and weakly developed ventral pocket (Fig. 89); with brush-like distal modifications of filiform cuticular projections (cf. Huber 2000: fig. 48). Bulb with several distinctive processes (here called 'processes a-e'; processes c-e sometimes absent) and membranous embolus arising from base of process a (e.g., Figs 19-20, 27, 39-40, 64).

LEGS. Without spines; with long curved hairs, especially on tibiae and metatarsi; retrolateral trichobothrium on tibia 1 at $8-10 \%$; prolateral trichobothrium present on all tibiae; tibia $2 /$ tibia 4 length usually $<1.0$, only in Artema doriae Thorell, $1881>1.0$; pseudosegmentation of tarsi not visible; tarsi 4 with distinct comb-hairs of the plesiomorphic, complex 'Belisana-type' (Huber \& Fleckenstein 2008).

\section{Female}

In general similar to male, but legs shorter (tibia 1: 5.3-16.5), and stridulatory files laterally on chelicerae always present and distinct (Figs 30,71, 154). Epigynal plate usually consisting of two sclerotized lateral areas (Fig. 15), sometimes with dark median sclerite anteriorly (Figs 48, 103, 138; variably large and variably distinct); with distinctive pair of anterior epigynal projections (AEP: Figs 15, 86, 103, 138). Cleared female epigyna are shown in dorsal views (Figs 201-207) and in posterior dorsal views (Figs 208-214); the diagnostic value of the female internal genitalia in Artema is unclear so we do not put further emphasis on this in the species descriptions.

\section{Natural history}

Like most other non-forest pholcids, representatives of the genus Artema live in dark and sheltered habitats such as caves, holes and crevices, and spaces under large rocks. However, they also occur in man-made habitats like bunkers, buildings and basements, and under concrete bridges (cf. Huber \& Kwapong 2013). In a large cave survey we conducted in Israel (Aharon 2016), we found most individuals of $A$. nephilit sp. nov. in caves in a very hot and arid zone with low mean annual precipitation $(50-150 \mathrm{~mm})$. Other 
species in the genus were also collected partly from very dry regions and arid deserts with less than $50 \mathrm{~mm}$ of annual precipitation, e.g., A. doriae at the Arava Valley, Israel, and Artema sp. b at El Goléa in the Algerian Sahara.

The web is made of non-sticky silk and often appears irregular. This may partly be due to the fact that webs accumulate over time to form huge masses of old silk full of exuviae, while the spider occupies only a small but more regular slightly domed sheet within this mass (Fig. 6). As usual in pholcids, females carry their egg sacs, but the silk cover is much denser than in most other pholcid genera observed (Fig. 3). For further data on natural history, see under A. nephilit sp. nov. description below.

\section{Distribution}

The type species $A$. atlanta Walckenaer, 1837 has a worldwide distribution, presumably as a result of human-aided transport (Fig. 2). All other species are restricted to the Old World, ranging from the African Sahel to Central and South Asia (Fig. 1).

\section{Relationships}

Together with eight other genera, Artema is a member of the subfamily Arteminae Simon, 1893, which currently contains 99 nominal species. Other genera included are: Wugigarra Huber, 2001; Trichocyclus Simon, 1908 and Holocneminus Berland, 1942 in Australia and Southeast Asia; Chisosa Huber, 2000; Aucana Huber, 2000 and Physocyclus Simon, 1893 in the New World, and the monotypic genera Tibetia Zhang, Zhu \& Song, 2006 and Nita Huber \& El-Hennawy, 2007 in Central Asia and northeastern Africa (Huber 2011b, 2016). The subfamily is characterized by two (functionally closely related) morphological synapomorphies, which constitute a pair of distinctive structures on the procursus: a dorsal process (dp: Fig. 89) and a ventral pocket (vp: Fig. 89) (Huber \& Eberhard 1997; Huber 2011b). Previous molecular studies supported the subfamily (e.g., Dimitrov et al. 2013), but current analyses of a much larger sample of taxa are ambiguous with respect to the positon of Artema (J. Eberle, A. Valdez-Mondragón, D. Dimitrov, B.A. Huber, unpublished data). Morphological data suggest that Artema is 'basal' within Arteminae, i.e., sister to all other genera. This is supported by the fact that all other Arteminae genera lack epiandrous spigots (Huber 2016). Internal relationships among species remain largely obscure. Some of the similarities described below (e.g., between $A$. transcaspica and $A$. doriae) are likely synapomorphic, while others (e.g., among A. nephilit sp. nov., A. bunkpurugu, A. atlanta and A. magna) may turn out to be homoplastic.

\section{Composition}

As construed here, the genus Artema includes eight nominal species: the type species A. atlanta Walckenaer, 1837; A. bunkpurugu Huber \& Kwapong, 2013; A. kochi Kulczyński, 1901 (revalidated); A. nephilit sp. nov.; A. doriae Thorell, 1881; A. transcaspica Spassky, 1934; A. magna Roewer, 1960; and the dubious $A$. ziaretana (Roewer, 1960) (which is based on a single juvenile specimen and might be a synonym of $A$. magna; see Notes under redescription of $A$. magna).

Based on known distribution patterns (no small-scale endemism), we do not expect a significantly higher species richness. However, some of our taxonomic decisions may prove wrong as more material becomes available and this may affect species numbers. In addition, specimens from northern Africa (Algeria, Sudan), the Arabian Peninsula (Yemen, Oman), the Middle East (Iran), and South Asia (Pakistan, India) that we do not formally describe may all represent additional species. 

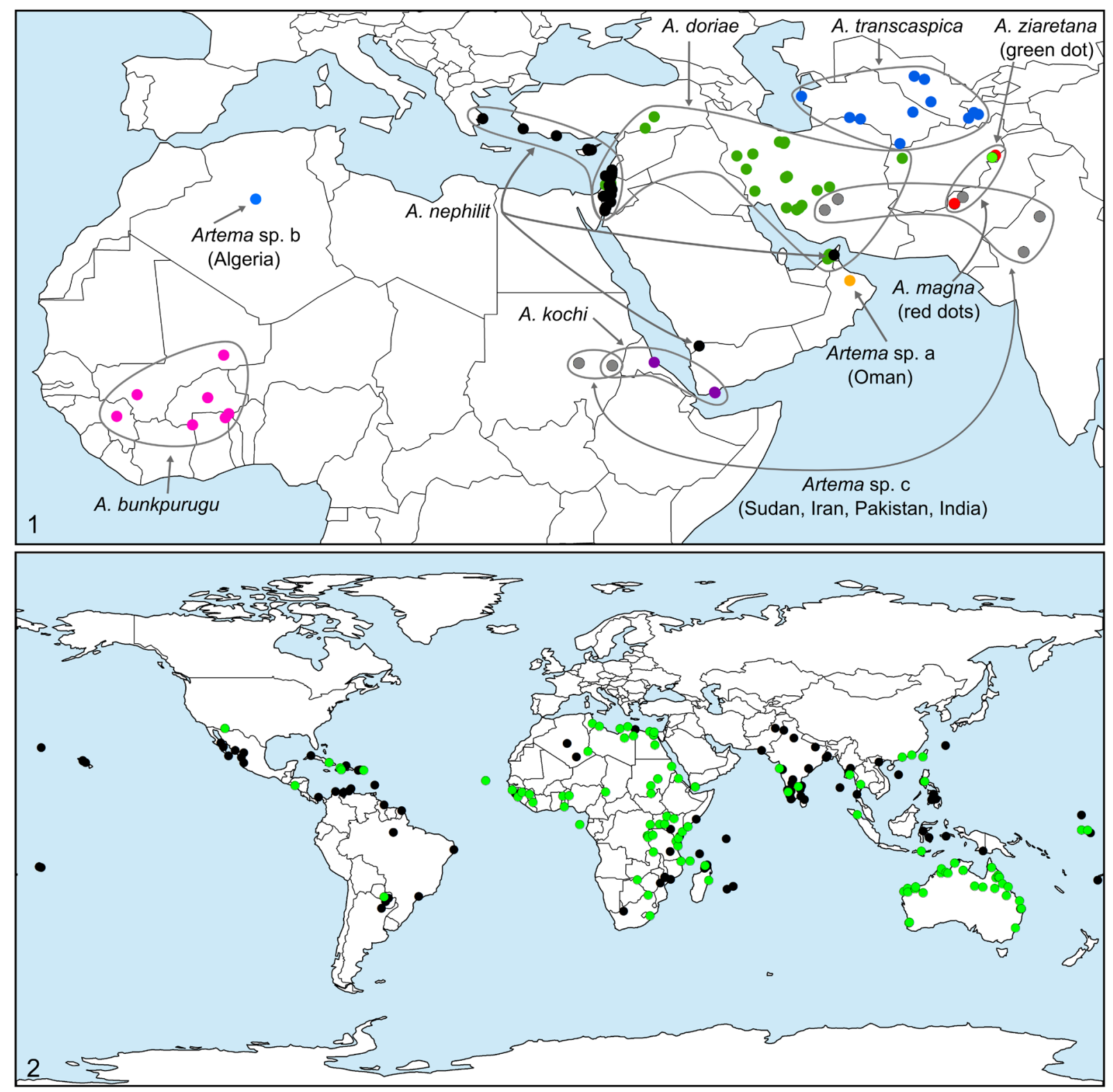

Figs 1-2. 1. Known distributions of species of Artema except A. atlanta Walckenaer, 1837. The Japanese record of $A$. doriae Thorell, 1881 is not shown as it is based on a single introduced specimen. 2. Known distribution of Artema atlanta. Green dots: specimens examined; black dots: specimens not examined (data from: Banks 1898; Beatty et al. 2008; Blackwell 1958; Bösenberg \& Lenz 1895; Brignoli 1981; Bryant 1940, 1948; Caporiacco 1928, 1948, 1949; Chamberlin 1924; Chrysanthus 1967; Colmenares 2008; Denis 1953; Doleschall 1857; Dyal 1935; Franganillo 1926a; Gao \& Li 2010; Gertsch \& Davis 1942; Gonzalez-Sponga 2005; Karsch 1879, 1892; Leardi in Airaghi 1902; Lessert 1936; Majumder \& Biswas 1993; Marples 1955; Mello-Leitão 1942; Millot 1946; Moenkhaus 1898; F.O.Pickard-Cambridge 1902; Petrunkevitch 1925, 1929; Pocock 1900; Saaristo 2001; Simon 1885, 1894; Taczanowsky 1874; Thorell 1895, 1898; Vinson 1863; Yaginuma 1970). Records from Israel, Belgium, and Britain are not shown as they are based on single introduced specimens. 


\section{Identification key}

\section{Males}

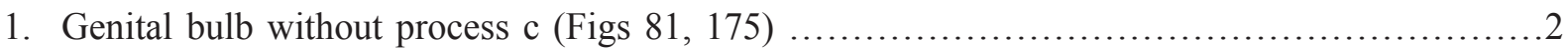

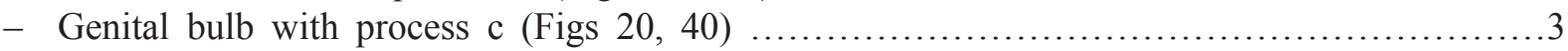

2. Genital bulb with bulbal process b flattened, rectangular distally (Fig. 81); cheliceral processes strongly projecting proximally with frontal rows of modified hairs (Fig. 83); with several coneshaped, sclerotized processes situated frontally near median line (arrows in Figs 83, 85)

Artema kochi Kulczyński, 1901

- Genital bulb with bulbal process b rather pointed (Fig. 175); cheliceral processes not strongly projecting proximally and without sclerotized processes near median line (Figs 177-178) ......

Artema sp.b(Algeria)

3. Genital bulb process $\mathrm{c}$ curved and pointing towards prolateral (Figs 40, 95) ................4

- Genital bulb process c different (either membranous and pointing towards process b, or with sclerotized ridge projecting perpendicular to process $\mathrm{b}$ and with small teeth prolaterally; Huber \& Kwapong 2013: fig. 58; Figs 20, 27, 29) …................................... 8

4. Genital bulb without process d (Fig. 39) or with low rounded projection on ventral side of bulb (Fig. 159). Cheliceral process with median projection (Figs 43-44, 164) ...............5

- Genital bulb with distinct process d (Figs 94, 125). Cheliceral process without median projection (Figs 98, 129, 192-194)

5. Genital bulb without process d (Fig. 39). Each chelicera with frontal row of about 20 modified hairs that splits distally, with outer branch ending at tip of process, inner branch ending at tip of median projection (Fig. 44)

Artema nephilit sp. nov.

- Genital bulb process d indistinct, low rounded projection on ventral side of bulb (Fig. 159). Chelicerae modified hairs on median projection not linked (by row of hairs) to main modified hairs ridge (as in A. nephilit sp. nov.) (Fig. 163) Artema magna Roewer, 1960

6. Chelicerae in lateral view without or with very indistinct ridge or process above modified hairs (Figs 128, 131-133) ....................................Artema transcaspica Spassky, 1934

- Chelicerae in lateral view with distinct ridge or process above modified hairs (Figs 100-102, 186191)

7. Chelicerae in lateral view with small ridge or process above modified hairs (Figs 100-102) Artema doriae Thorell, 1881

- Chelicerae in lateral view with robust ridge or process above modified hairs (Figs 186-191) ...... Artema sp. c (India, Pakistan, Iran, Sudan)

8. Genital bulb process $\mathrm{c}$ partly membranous and directed towards process $\mathrm{b}$; processes $\mathrm{d}$ and e absent. Chelicerae with frontal row of about ten modified hairs in straight line on each side (cf. Huber \& Kwapong 2013: figs 59-60) Artema bunkpurugu Huber \& Kwapong, 2013

- Genital bulb process c with sclerotized ridge projecting prolaterally perpendicular to process $b$, with small teeth prolaterally on round end of process (Figs 20, 27, 29); processes d and e present (both low and rounded) (Fig. 19). Chelicerae with frontal rows of about 20 modified hairs each in s-shaped pattern (Fig. 24)

Artema atlanta Walckenaer, 1837

\section{Females}

1. Anterior epigynal projections (AEP) sclerotized and elongated (Fig. 86); epigynal plate wide rectangular, with triangular anterior projection between AEP ......Artema kochi Kulczyński, 1901

- Anterior epigynal projections (AEP) not or only weakly sclerotized and not elongated; epigynal plate different 
2. Epigynal plate rectangular, without dark median sclerite and without prominent pale median area (Fig. 170) ...................................................Artema sp. a (Oman)

- Epigynal plate different, either with dark median sclerite and/or prominent pale median area ...3

3. Epigynal plate posterior margin strongly indented (Fig. 15) .....Artema atlanta Walckenaer, 1837

- Epigynal plate posterior margin either straight (Figs 46, 105), gently indented (Figs 135, 143) or protruding (Fig. 169) ..................................................................... 4

4. Anterior epigynal projections (AEP) distinctively prominent and pointed (cf. Huber \& Kwapong 2013: figs 49, 53-54) ................Artema bunkpurugu Huber \& Kwapong, 2013

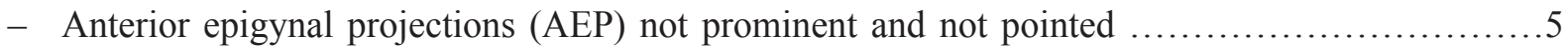

5. Epigynal plate $\sim 2.5 \times$ wider than long; median posterior margin distinctively protruding (Fig. 169) Artema magna Roewer, 1960

- Epigynal plate less than $\sim 2.5 \times$ wider than long, median posterior margin not protruding ........6

6. Epigynal plate with long dark median sclerite fused at posterior epigynal margin with lateral sclerotized plates (Figs 134-145) .........................Artema transcaspica Spassky, 1934

- Epigynal plate long with dark median sclerite not fused at posterior epigynal margin with lateral sclerotized plates (Figs 45-50, 103-114, 195-199) ..........................................

7. Epigynal plate pale median area very inflated and prominent (Figs 195-200) .Artema sp. c (India, Pakistan, Sudan, Iran)

- Epigynal plate pale median area slightly inflated or not inflated ............................ 8

8. Epigynal plate posterior margin almost straight, gently undulating. Pale median area with distinct dark median sclerite $1 / 3-1 / 2$ the length of epigynal plate (Figs 45-50) .....Artema nephilit sp. nov.

- Epigynal plate trapezoidal, i.e., wider posteriorly; pale median area slightly inflated posteriorly; dark median sclerite $1 / 3-2 / 3$ the length of epigynal plate; dark median sclerite not fused at posterior epigynal margin with lateral sclerotized plates (Figs 103-114) ...Artema doriae Thorell, 1881

\section{Artema atlanta Walckenaer, 1837}

Figs 2-3, 15-34, 201, 208

Artema atlanta Walckenaer, 1837: 656-657 (o̊ ㅇ, Brazil).

Artema mauriciana Walckenaer, 1837: 657-658, pl. 15, fig. 1 ( $ぇ$ †, Mauritius). Synonymized by Pickard-Cambridge 1902: 366.

Pholcus sisyphoides Doleschall, 1857: 408-409 (Indonesia). Synonymized by Pickard-Cambridge 1902: 366.

Artema convexa Blackwall, 1858: 332-334 (, Brazil). Synonymy with A. sisyphoides suggested by Thorell 1881: 179; synonymized with "A. mauricia" by Simon 1885: 19.

Pholcus borbonicus Vinson, 1863: 132-135, 307, pl. 3, figs 4, 4a (§ 우, Réunion, Mauritius). Transferred and synonymized (with "A. mauricia") by Simon 1885: 19.

Pholcus rotundatus Karsch, 1879: 106-107 (क, Colombia). Transferred and synonymized (with “A. mauricia”) by Simon 1893: 465.

Crossopriza sexsignata Franganillo, 1926a: 49 (Cuba). Synonymized by Pérez González 1996: 431432.

Coroia magna González-Sponga, 2005: 102, pl. 2, figs 1-11. Synonymized by Huber et al. 2014: 417.

Artema atlanta-Simon 1894: 519 (A. atalanta-lapsus) (St. Vincent). — Taczanowski 1874: 103 (French Guiana). — Banks 1898: 212 (A. atlantica - lapsus) (Mexico). — Moenkhaus 1898: 86 (Brazil). Pocock 1900: 238-239, fig. 81 (India, Myanmar, Sri Lanka, Pakistan). — Pickard-Cambridge 1902: 
AHARON S. et al., Revision of the spider genus Artema (Araneae, Pholcidae)

366, pl. 34, figs 15, 15a-b, 16, 16a (Mexico, Brazil, India, Pakistan). - Petrunkevitch 1911: 156; 1925: 66 (Panama); 1929: 119-120, figs 102-104 (Puerto Rico). — Mello-Leitão 1918: 89-91 (Brazil); 1941: 244 (Colombia); 1942: 382 (Argentina); 1946: 33 (Paraguay). — Sherriffs 1919: 228 (India). — Chamberlin 1924: 632 (Mexico). — Gertsch 1935: 10 (USA). — Dyal 1935: 170171, pl. 15, figs 97-103 (India). — Bryant 1940: 289 (Cuba); 1948: 366 (Dominican Republic). — Gertsch \& Davis 1942: 7 (Mexico). — Caporiacco 1948: 626-627 (Guyana); 1949: 326 (Kenya). Chrysanthus 1967: 92-96, figs 15-19 (Curaçao, New Guinea, Tanzania, "Sandwich Isl." = Hawaii?). — Yaginuma 1970: 646 (Japan). — Tikader 1977: 164-165 (India). — Brignoli 1981: 92, figs 1-7 (USA, Mexico, Brazil, Egypt). — Tikader \& Biswas 1981: 18, fig. 12. — Majumder \& Biswas 1993: 1 (India). — Pérez González 1996: 431-432 (Cuba). — Saaristo 1999: 2, 8 (Seychelles); 2001: 15-17, figs 16-22 (Seychelles, India, Indonesia, Sri Lanka, Vietnam); 2010: 159, figs 25.15. - Huber 2000: 342, figs 12-13, 48, 56-57, 99, 121, 145, 169, 195 (SEM); 2001: 135-136 (Australia). - Murphy \& Murphy 2000: 246-247. — van Keer \& van Keer 2001: 82 (Belgium). — Lee 2005: 7 (Great Britain, in container). — Colmenares-García 2008: 87, figs 1a-c (Venezuela). — Beatty et al. 2008: 3-7, figs 15-16, 42-43 (Micronesia, Polynesia, Indonesia). - Irie 2009: 106, figs (2-2-13) 1-2, pl. 4, fig. 1. — Gao \& Li 2010: 11-13, figs 1-3 (China). — Huber \& Warui 2012: 3, fig. 1 (Kenya, Uganda, Somalia, Tanzania). - Huber \& Kwapong 2013: 7 (Guinea, Togo, Benin). Artema mauriciana - Vinson 1863: 141-142, 307-308 (A. mauricia - lapsus) (Mauritius). -

Simon 1885: 19 (A. mauricia - lapsus) (India); 1887: 453 (A. mauricia - lapsus) (Djibouti); 1893: 463-465 (A. mauricia - lapsus); figs 441, 451-454; 1908: 426-427 (Libya). — Kulczyński 1901: pl. 1, fig. 15 (A. mauricia - lapsus). - Leardy Airaghi 1902: 348 (A. mauricia - lapsus) (India). Tullgren 1910: 119, pl. 2, fig. 35 (Tanzania). - Caporiacco 1928: 91 (A. mauricia - lapsus) (Libya); 1936: 86 (Libya). — Lessert 1936: 233-234 (Mozambique). — Millot 1941: fig. 1F only (Guinea); 1946: 129, fig. 1 (Madagascar). — Denis 1953: 320 (Algeria). — Marples 1955: 465 (Samoa).

Pholcus sisyphoides - Thorell 1881: 179-180 ("ins Elephanta", Hawaii).

Artema sisyphoides - Karsch 1892: 276 (Sri Lanka). — Thorell 1895: 69-70 (Myanmar); 1898: 274 (Myanmar).

Artema convexa - Blackwall 1866: 459-460 (“Equatorial Africa"); 1867: 394 (India).

Pholcus borbonicus - Simon 1873: 47-48 (Egypt). — Lenz 1886: 395 (Madagascar); 1891: 173

(Madagascar). — Bösenberg \& Lenz 1895: 40 (Mozambique).

Crossopriza sexsignata - Franganillo 1926b: 11; 1936a: 46; 1936b: 77.

\section{Misidentifications}

"Artema atlanta" - Dalmas 1920 (see A. nephilit sp. nov.). - Feng 1990: 45 (misidentification of Physocyclus globosus).

"Artema mauriciana" - Bodenheimer 1937: 238 (see A. nephilit sp. nov.). — Millot 1941:3-5, figs 1A-I (except fig. 1F; misidentification of A. bunkpurugu; see Huber \& Kwapong 2013).

"Pholcus borbonicus" - L. Koch 1875: 25-26. — Simon 1882: 234 (see A. kochi).

"Tibiosa coreana" - González-Sponga 2006: pl. 3, figs 8-9 only (see Huber 2009).

\section{Diagnosis}

Males are easily distinguished from all known congeners by their bulbal processes: process c (Fig. 20) with sclerotized ridge projecting prolaterally perpendicular to process $b$ with small teeth prolaterally on round end of process (Figs 27, 29); process d rounded (Figs 19, 27) rather than pointed as in A. doriae and $A$. transcaspica; process e present and rounded. Males differ also by two deep dorsal notches on distal margin of procursus, with lighter cuticle than rest of procursus (arrows in Fig. 20). Females differ from other congeners by strongly indented posterior epigynal margin (Fig. 15). 


\section{Types}

BRAZIL: Artema atlanta Walckenaer, 1837: syntypes ồ, $q$ probably lost (no further data).

MAURITIUS: Artema mauriciana Walckenaer, 1837: syntypes ${ }^{\AA}$, $q$ probably lost $\left[20.2^{\circ} \mathrm{S}, 57.5^{\circ} \mathrm{E}\right.$ ] (no further data).

INDONESIA: Pholcus sisyphoides Doleschall, 1857: holotype $\overbrace{}^{\Uparrow}$ probably lost; Amboina $\left[3.6^{\circ} \mathrm{S}\right.$, $\left.128.1^{\circ} \mathrm{E}\right]$.

BRAZIL: Artema convexa Blackwall, 1858: syntypes 우우 probably lost; Pernambuco [8.0 $\left.\mathrm{S}, 35.0^{\circ} \mathrm{W}\right]$.
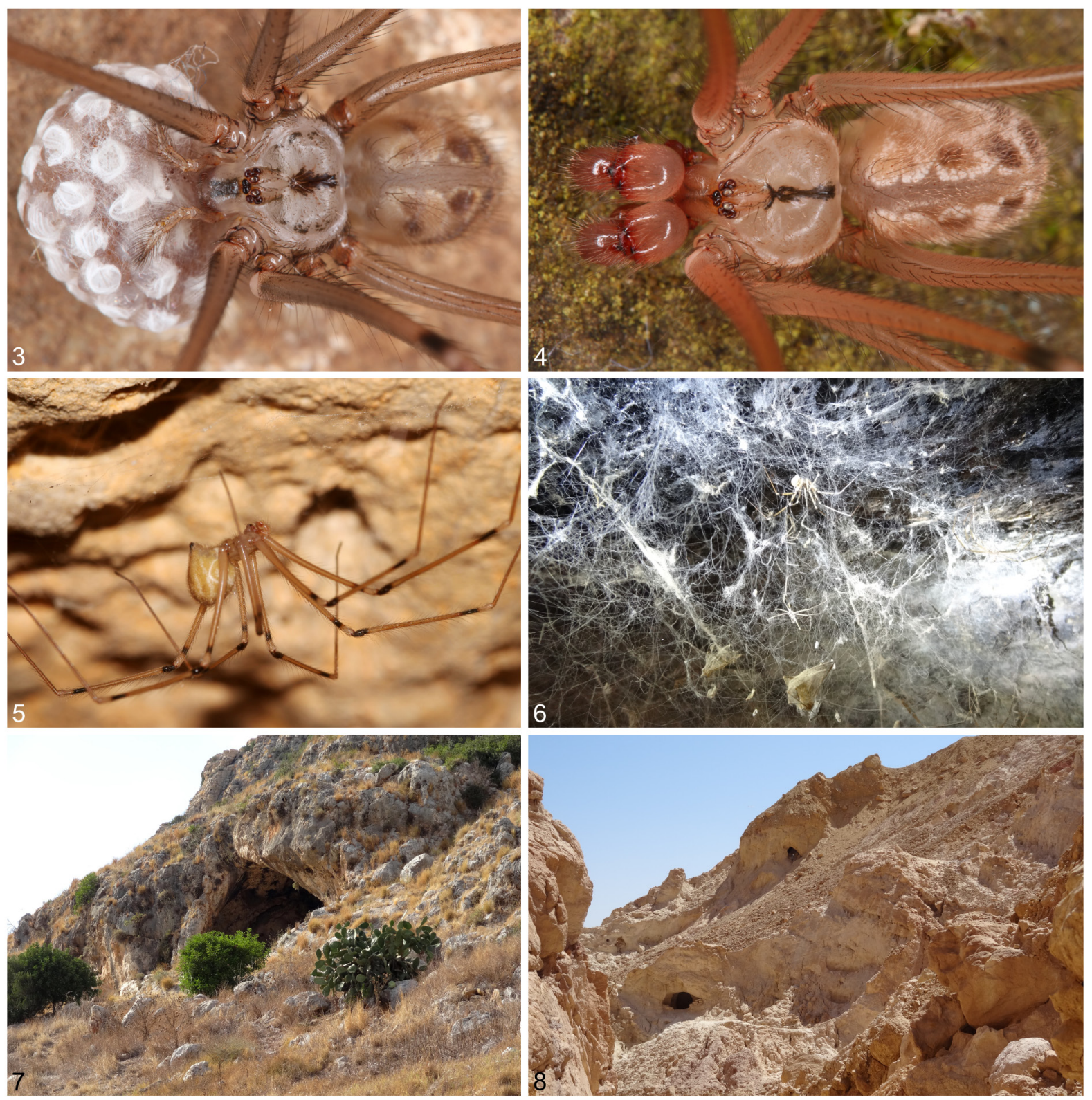

Figs 3-8. Live specimens and habitats. 3. Artema atlanta Walckenaer, 1837 from Thailand, Ratchaburi. 4-5. A. nephilit sp. nov. from Israel. 6. Typical Artema web mass, in a cave in Petra, Jordan. 7-8. Caves populated by Artema nephilit sp. nov.: Oren Cave, Mount Karmel (7) and caves in the Eilat Mountains (8), Israel. Photos: BAH (3-4, 6-8), SA (5). 
AHARON S. et al., Revision of the spider genus Artema (Araneae, Pholcidae)

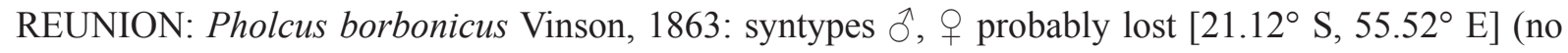
further data).

COLOMBIA: Pholcus rotundatus Karsch, 1879: syntype(s?) + probably lost; Santa Marta $\left[11.24^{\circ}\right.$ N, $\left.74.20^{\circ} \mathrm{W}\right]$.

CUBA: Crossopriza sexsignata Franganillo, 1926: syntypes $\hat{\jmath}$, $q$ probably lost; Habana, Luyanó, $\left[23.10^{\circ} \mathrm{N}, 82.34^{\circ} \mathrm{W}\right]$.

VENEZUELA: Coroia magna González-Sponga, 2005: holotype $\delta$ and $1 q$ paratype; Falcón State, $10 \mathrm{~km}$ SE from Coro $\left(11.20^{\circ} \mathrm{N}, 69.50^{\circ} \mathrm{W}\right)$, Mar. and Dec. 1999, E. Bravo and V. Wall leg., in Museo del Instituto de Zoología Agrícola of the Universidad Central de Venezuela 1440 a,b, not examined.

Material examined (arranged from west to east)

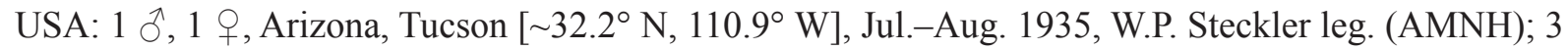

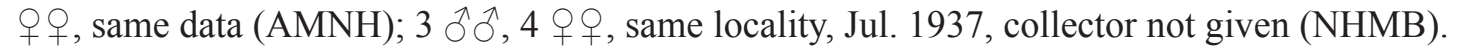

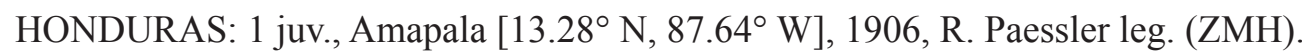

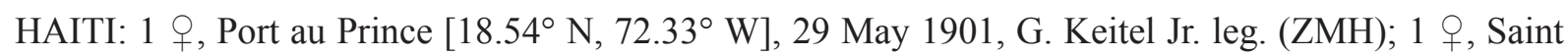
Marc $\left[19.10^{\circ} \mathrm{N}, 72.70^{\circ} \mathrm{W}\right], 1905$, C. Gazgo leg. (ZMH).

VIRGIN ISLANDS: 1 juv., St. Thomas [18.33 N, 64.91 W], 28 Mar. 1898, L.D. Calwood leg. (ZMH).

PARAGUAY: 2 $q$, date and locality not given $\left[\sim 23.5^{\circ} \mathrm{S}, 58.1^{\circ} \mathrm{W}\right]$, Wiengreen leg. (ZMH).

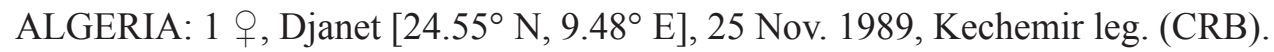

TUNISIA: 7 ふぇ, 2 우, numerous juvs, Djerba $\left[33.80^{\circ} \mathrm{N}, 10.88^{\circ} \mathrm{E}\right]$, date not given, Vibert leg. (MNHN AR 10170).

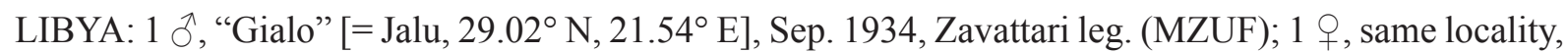
Jan. 1934, Di Caporiacco leg. (MZUF); 1 ô, same locality, 4-5 May 1931(?), collector not given (MSNG); 1 ठૈ, same locality ("Oajo di Gialo"), Jul. 1931(?), collector not given (MSNG); 1 q, same locality (“Gialo"), Apr. 1931(?), collector not given (MSNG); 1 đ, 1 \%, same locality, 30 Apr. 1931, collector not given (MSNG); 6 우, 6 juvs, "Giarabub" [=Al Jaghbub, 29.74 N, 24.51 ${ }^{\circ}$ E], Jun. 1926-Mar. 1927, Confalonieri leg. (MSNG); 1 ㅇ, with two locality labels: "Giarabub" [= Al Jaghbub, 29.74 ${ }^{\circ} \mathrm{N}, 24.51^{\circ} \mathrm{E}$ ],

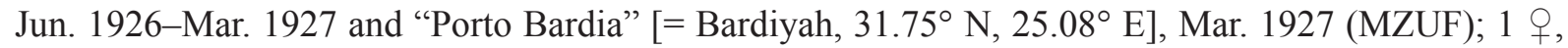
Tripoli $\left[32.86^{\circ} \mathrm{N}, 13.17^{\circ} \mathrm{E}\right], 1906$, Klaptocz leg. (ZMH).

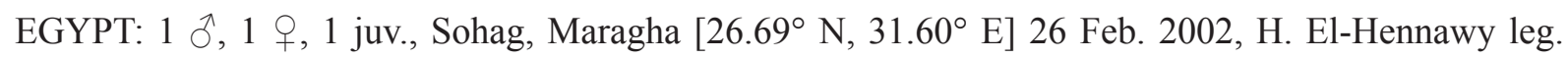
(ZFMK Ar 15215); 1 `े, 7 우, numerous juvs, Alexandria $\left[31.19^{\circ} \mathrm{N}, 29.91^{\circ} \mathrm{E}\right]$, and Suez $\left[29.96^{\circ} \mathrm{N}\right.$, $32.54^{\circ} \mathrm{E}$ ], date not given, E. Simon leg. (MNHN AR 10155, 392); 2 우, near Cairo [ 30.0 $\left.\mathrm{N}, 31.2^{\circ} \mathrm{E}\right]$, 1911, E. Graeter leg. (NHMB 1041a, 1402b); $3{ }^{\wedge} \hat{o}^{\lambda}$, Mansurah $\left[31.04^{\circ} \mathrm{N}, 31.37^{\circ} \mathrm{E}\right]$, date not given, I. Sörensen leg. (ZMUC).

CAPE VERDE: 1 †, Fogo, São Filipe $\left[14.89^{\circ} \mathrm{N}, 24.49^{\circ} \mathrm{W}\right]$, in bathroom, on web, 9 Nov. 1998, W. Tavernier leg. (MRAC 208404).

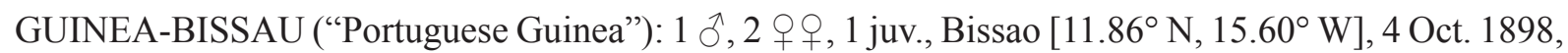
H. Eberhardt leg. (ZMH); 1 juv., same data (ZMH). 
GUINEA and BENIN: see Huber \& Kwapong (2013).

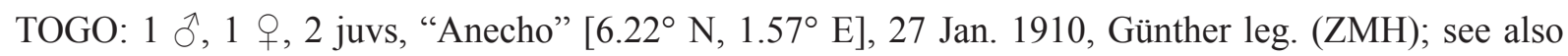
Huber \& Kwapong (2013).

SÃO TOMÉ AND PRÍNCIPE: 1 q, "S. Thomé” [= São Tomé, $0.34^{\circ}$ N, 6.73 E], 1879, R. Greef leg. (ZMH no. 31).

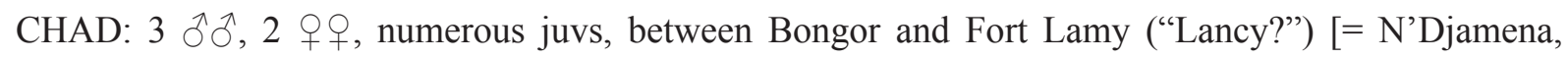
$\left.\sim 11.1^{\circ} \mathrm{N}, 15.2^{\circ} \mathrm{E}\right]$, Nov.-Dec. 1965, Y. Brandily leg. (MRAC 132893).

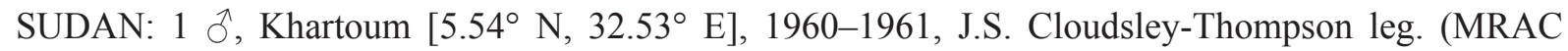
120764); $1 \hat{\delta}$, same data (MRAC 120766); 1 $\hat{\delta}, 1$ ๆ, 2 juvs, (South) Kordofan, Talodi $\left[10.63^{\circ} \mathrm{N}\right.$,

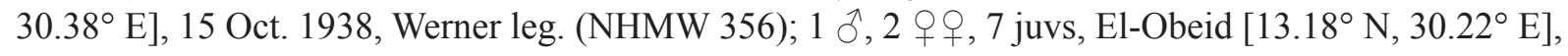
Mar. 1914, D.G. Mainhof leg. (ZMH).

ERITREA: 1 ○, 2 우, 1 juv., Massawa, 1870, Beccari leg. (MSNG).

YEMEN-ERITREA: 1 đ̊, 2 우, 1 juv., Aden $\left[12.86^{\circ} \mathrm{N}, 44.98^{\circ} \mathrm{E}\right]$ and Massawa $\left[15.61^{\circ} \mathrm{N}, 39.45^{\circ} \mathrm{E}\right]$, 1889, E. Simon leg. (“393” part) (MNHN AR 10169 part).

SOMALIA: 1 +, 1 juv., locality unknown (“339.76", "Mag. no. 866”), 1924, Stefanini and Puccioni leg. (MZUF); 2 우, locality unknown ("1140 20"), 1924, Stefanini and Puccioni leg. (MZUF); 1 , Kismayo [0.35 $\mathrm{S}, 42.54^{\circ} \mathrm{E}$ ], under stones, 16 Apr. 1993, Vercammen Gino leg. (MRAC 177.415).

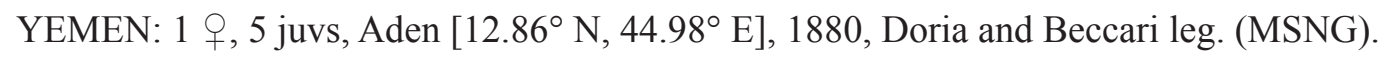

DR CONGO: 3 우, numerous juvs, Kivu, Uvira between Kolundu and Kavimvira [3.34 ${ }^{\circ} \mathrm{S}, 29.15^{\circ} \mathrm{E}$ ], Jun. 1961, R. Kiss leg. (MRAC 119889); 2 juvs, same data (MRAC 119917); 1 q, Mutelemuko, Uvira $\left[\sim 3.40^{\circ} \mathrm{S}, 29.12^{\circ} \mathrm{E}\right], 1954$, J. Bouillon leg. (MRAC 76923).

BURUNDI: 1 juv., "Usumbura" (= Bujumbura) (3.36 S, 29.36 E), Jan. 1926, H. Schouteden leg.

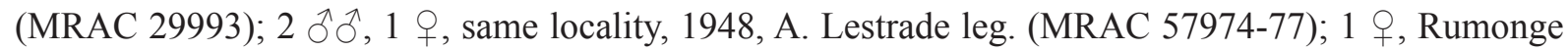
[3.97 S, 29.43 E], 1934, A. Lestrade leg. (MRAC 24696).

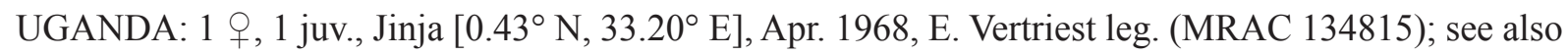
Huber \& Warui (2012).

TANZANIA: 2 우, Dar es Salaam, UDSM campus [6.77 S, 39.20 E], 1970-1971, K.M. Howell leg. (MRAC 159428); 1 ㅇ, "near Msala, Tanganyika Terr." [ 3.16 ${ }^{\circ} \mathrm{S}, 30.98^{\circ}$ E], date not given ("Kuipper 64”) (SMF); see also Huber \& Warui (2012).

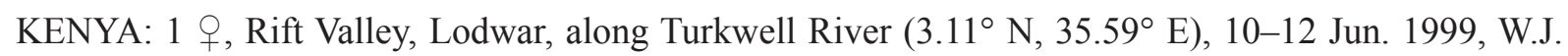
Pulawski and J.S. Schweikert leg. (CAS); $1{ }^{\circ}$, Gabraland, Marsabit area $\left[2.33^{\circ} \mathrm{N}, 37.98^{\circ} \mathrm{E}\right], 17 \mathrm{Jan} .1978$ (from artifact in CAS anthropology collection) (CAS); 1 ○, "Ostafrika Waboniland" [2.07 $\left.{ }^{\circ} \mathrm{S}, 40.70^{\circ} \mathrm{E}\right]$, 15 Oct. 1938, Haessler leg. (NHMW 355); see also Huber \& Warui (2012).

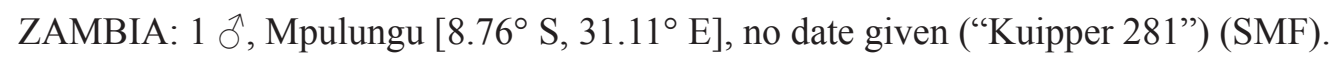

ZIMBABWE: 1 J , Victoria Falls $\left(17.933^{\circ} \mathrm{S}, 25.833^{\circ} \mathrm{E}\right), 29$ Nov. 1996, W. Pulawski and V. Ahrens leg. (CAS). 
MOZAMBIQUE: $1 \partial^{\Uparrow}$, numerous juvs, “Cucuta/ Brasilien” [Cucuta, $11.83^{\circ} \mathrm{S}, 40.24^{\circ} \mathrm{E}$ ], 29 Sep. 1887 , W. Bösenberg leg. (ZMH).

SOUTH AFRICA: 1 đo, KwaZulu Natal, Durban $\left(29.850^{\circ}\right.$ S, $30.016^{\circ}$ E), 10 m a.s.1., 8 Jan. 2001, C. Whitmore leg. (DNSM); 3 juvs, Limpopo, Lajuma Mountain Retreat $\left(23.037^{\circ} \mathrm{S}, 29.441^{\circ} \mathrm{E}\right)$, sifting leaf litter, 1325 m a.s.1., 10 Nov. 2012, J.A. Neethling leg. (ZFMK Ar 15216).

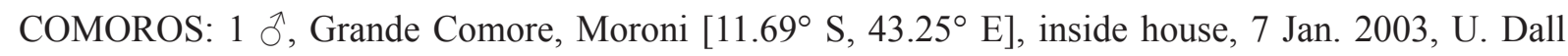
'Asta leg. (MRAC 215035).

MADAGASCAR: 1 + , Tamatave $\left[18.15^{\circ} \mathrm{S}, 49.40^{\circ} \mathrm{E}\right], 12$ May 1885, A. O’Swald leg. (ZMH 7791);

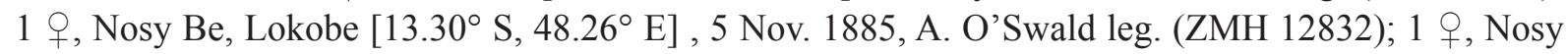
Be, 13 Mar. 1908, collector not given (ZMH).

INDIA: 3 우, 2 juvs, Bombay, "Elephanta" [= Gharapuri, $18.96^{\circ}$ N, 72.93 E], 18 Sep. 1877, Beccari

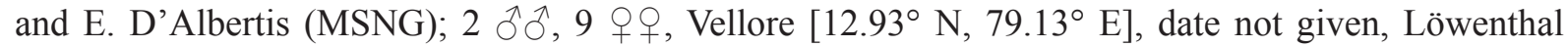
leg. (ZMUC); 1 ㅇ, 1 juv., Tuticorin $\left[8.76^{\circ} \mathrm{N}, 78.13^{\circ} \mathrm{E}\right]$, collected in container arrived at Haifa port $\left[32.82^{\circ} \mathrm{N}, 34.99^{\circ}\right.$ E], 5 Jun. 2012, E. Gavish-Regev leg. (SMNH AR 50186); 1 §, Kerala, Malabar, Feroke $\left[11.18^{\circ} \mathrm{N}, 75.85^{\circ} \mathrm{E}\right]$, date and collector not given (SMF).

MYANMAR: 3 ふึ๙, 14 우, “fra Rangoohn” [Rangoon, $16.84^{\circ} \mathrm{N}, 96.14^{\circ} \mathrm{E}$ ], date not given, Lövendal leg. (ZMUC).

THAILAND: 1 đิ, 2 q , Ratchaburi, Wat Huai Takaeng $\left(13.587^{\circ} \mathrm{N}, 99.758^{\circ} \mathrm{E}\right), 30 \mathrm{~m}$ a.s.1., in cave, 15 Mar. 2015, B.A. Huber and B. Petcharad leg. (ZFMK Ar 15217); 1 juv., in pure ethanol, same data (ZFMK Mal 374).

CHINA: 1 q, Canton [22.67 $\mathrm{N}, 113.60^{\circ}$ E], 8 Aug. 1904, W. Helms leg. (ZMH); 1 §, "Swatow" [= Shantou, $23.33^{\circ} \mathrm{N}, 116.68^{\circ} \mathrm{E}$ ], date and collector not given (MNHN AR 10166).

TAIWAN: 1 q, 2 juvs, “Takao, Formosa” [= Kaohsiung, 22.77 N, 120.42 E], 1 Nov. 1908, W. Schwinghammer leg. (ZMH).

PHILIPPINES: $1 \widehat{\partial}$, Manila [14.61ํ N, 121.04 E], 10 Jun. 1945, T. Aarons leg. (CAS).

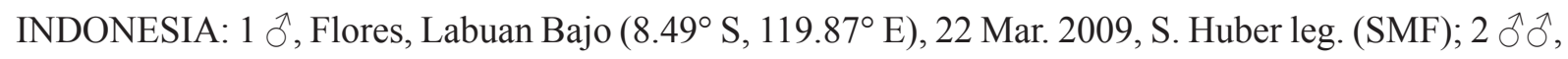
4 우, 4 juvs, Sumatra, Medan [3.61 ${ }^{\circ}$ N, $98.67^{\circ}$ E], 15 Oct. 1938, Fulmek leg. (NHMW).

AUSTRALIA: Numerous specimens from Western Australia, Northern Territory, and Queensland were examined but not listed in detail by Huber (2001). We have not reexamined those specimens.

Locations not clear: 2 우, “El Bur” (Somalia?), "Mag. no. 1220”, 15 Aug. 1968 (“SBS”, “977”) (MZUF); 1 §̃, 1 juv., "Museat, Jayakan, 22" (NHMUK); 1 q, 1 juv., "Westindien”, 3 Sep. 1906, C. Gazgo leg. (ZMH).

\section{Description}

Male (Myanmar: Rangoon, ZMUC)

MEAsuREMENTS. Total body length 9.6, carapace width 4.0. Leg 1: $48.4(16.0+1.6+16.6+22.5+2.6)$, tibia 2: 12.6, tibia 3: 9.5, tibia 4: 13.0; tibia $1 \mathrm{~L} / \mathrm{d}$ : 42. Distance PME-PME $210 \mu \mathrm{m}$, diameter PME $210 \mu \mathrm{m}$, distance PME-ALE $110 \mu \mathrm{m}$, distance AME-AME $60 \mu \mathrm{m}$, diameter AME $180 \mu \mathrm{m}$. 
Color. Carapace ochre beige, with light brown median band and small dots laterally; ocular area light brown; clypeus with light brown band fading towards edge, with brown rim (as in Fig. 3); legs light ochre, with dark rings on femora subdistally, patellae + tibiae proximally, and tibiae subdistally; sternum light ochre with two small light brown marks posteriorly, with narrow light brown margins; abdomen pale ochre with pale and dark dots forming large marks dorsally and stripes laterally.

BoDy. Ocular area slightly elevated; carapace with median pit and distinct posterior furrow; clypeus unmodified; sternum wider than long (2.5/2.2); chelicerae as in Figs 22-24, with frontal row of 20 modified (cone-shaped; cf. Huber 2000: figs 12-13) hairs on each side in s-shaped pattern (as in Fig. 24); stridulatory ridges absent (as in Fig. 31); abdomen globose and high; gonopore with four epiandrous spigots (cf. Huber 2000: fig. 121); ALS with several cylindrical spigots in addition to widened and pointed spigot (as in Figs 26, 28) (cf. Huber 2000: fig. 169); PMS with two pointed spigots each (as in Fig. 25) (cf. Huber 2000: fig. 195).

PALPS. As in Figs 16-18; coxa unmodified; trochanter with short ventral projection; femur with short, somewhat pointed retrolateral process and small dorsal projection proximally; ventral membranous area proximally bordered on both sides by sclerotized ridges; femur-patella hinges close together dorsally; patella very short; procursus with proximal dorsal process and weakly developed ventral pocket; with two distal dorsal notches on sclerotized margin (arrows in Fig. 20); bulb with membranous embolus arising from base of processes $a$ and $b$ (as in Fig. 27; cf. Huber 2000: fig. 56), process a long, somewhat inflated; process b elongated and pointed, process $\mathrm{c}$ (as in Figs 20,27) with sclerotized ridge projecting prolaterally perpendicular to process $b$, with small teeth prolaterally on round end of process (as in Fig. 29) (cf Huber 2000: fig. 57), processes $d$ and e low and rounded (as in Figs 19, 27).

LEGS. Without spines, with long curved hairs, especially on tibiae and metatarsi; retrolateral trichobothrium on tibia 1 at $9 \%$; prolateral trichobothrium present on all tibiae; pseudosegmentation not visible (cf. Huber 2000: fig. 99). Comb-hairs on tarsi 4 variant of complex 'Belisana-type' (cf. Huber \& Fleckenstein 2008: figs 17-18).

Male (variation)

Tibia 1 in 19 other males: 12.0-19.0 (mean 15.4); color pattern on abdomen varies from distinct stripes consisting of dark and pale dots on pale to brown-ochre background, to pale without any pattern; leg color varies from pale to ochre, prolateral ochre mark on patella 1 proximally sometimes absent; ocular area light brown to ochre; lateral dots on carapace vary from round radiating pattern to small indistinct marks; cheliceral modified hairs vary in numbers $(\sim 17-20)$, sometimes sclerotized ridge very dark and pattern of modified hairs hard to distinguish, one male with small process medial of sclerotized ridge (from Khartoum, Sudan; MRAC 120766); brown marks posteriorly on sternum variable; one male with procursus notches almost fused to one large notch without sclerotized line between them (from Shantou, China; MNHN AR 10166). No variation observed in numbers of epiandrous spigots.

\section{Female}

In general similar to male; tibia 1 in 20 females: 9.2-17.2 (mean 13.2); stridulatory files laterally on chelicerae present (Fig. 30); epigynal plate trapezoidal (posteriorly wider), posterior margin with deep median indentation (Figs 15, 33); epigynal plate consisting of two sclerotized lateral areas that appear swollen posteriorly, usually light brown, sometimes very pale at lateral posterior edge, with light brown to pale median area, and dark sclerite anteriorly (variably large and variably distinct), posterior rim sometimes slightly sclerotized; pair of projections anterior to epigynum (AEP) ovoid, sometimes with variable light brown marks anteriorly. 


\section{Natural history}

Like other species in the genus, A. atlanta inhabits caves as well as buildings and basements. Similar to several other pholcid genera, such as Crossopriza Simon, 1893, Micropholcus Deeleman-Reinhold \& Prinsen, 1987, Modisimus Simon, 1893, Pholcus Walckenaer, 1805, Physocyclus Simon, 1893 and Smeringopus Simon, 1890, it is not clear why this is the only species in the genus that has spread all over the world. Another surprising fact is that, to the best of our knowledge, no study on the biology of this widespread species has ever been conducted.

\section{Distribution}

Artema atlanta is the only species in this small genus with a worldwide distribution (Fig. 2). It is widespread from the subtropical Americas through Africa and India, the Far East and Australia. It can be assumed from the genus distribution that $A$. atlanta was originally an Old World species, like the other species in the genus, which expanded its distribution worldwide (Brignoli 1981). Intriguingly, A. atlanta is almost entirely absent from the large area where congeneric species occur (Arabian Peninsula, Middle East, Central Asia).

It seems that in several parts of the world, A. atlanta was more common a century ago than it is now. For example, Mello-Leitão (1918) reported the species to be very common along the Brazilian coast (“... muito commun em todo o littoral do Brazil ...”). Nowadays, this is definitely not the case (not a single encounter during seven collecting trips along the coast ranging from the Brazilian states of Rio Grande do Sul to Rio Grande do Norte; B.A. Huber, unpublished data). Likewise, the species was reported frequently from the Caribbean until the mid $20^{\text {th }}$ century (Simon 1894; Franganillo 1926a, 1926b, 1936a, 1936b; Petrunkevitch 1929; Bryant 1940, 1948) but not thereafter. Intensive collecting in Cuba, Hispaniola, Jamaica, Puerto Rico, and the Lesser Antilles between 1999 and 2012 has not produced a single specimen (B.A. Huber and I. Agnarsson, unpublished data).

\section{Artema nephilit sp. nov. urn:1sid:zoobank.org:act:8C0CA94A-B5CF-4585-B51D-FF25711103E5}

Figs 1, 4-6, 9-14, 35-75, 203, 210

“Artema mauriciana" (misidentification) - Bodenheimer 1937: 238 ("Palestina”); see Notes below. "Artema mauricia" (misidentification) - Dalmas 1920: 59 (Bodrum, Turkey).

\section{Diagnosis}

Males can be distinguished from all known congeners by their bulbal processes: process c (Fig. 40) projecting prolaterally, processes $\mathrm{d}$ and e absent (Fig. 39) (A. magna: process c robust, strongly curved prolaterally, process d distinct rounded projection on ventral side of bulb - see Figs 159-160; A. doriae and $A$. transcaspica: process d small, pointed towards ventrodistally) and by unique median projection on each male cheliceral process (Figs 43-44, 67) (only A. magna with similar median projection but no modified hairs connect to main ridge as in $A$. nephilit sp. nov. - see Figs 163-164). Females with semicircular epigynum (Figs 45-50); differing from $A$. atlanta by straight posterior epigynal margin; from A. magna by epigynal plate length to width ratio; from A. bunkpurugu by much less prominent anterior epigynal projections (AEP in Fig. 48) (cf. Huber \& Kwapong 2013: figs 49, 53-54).

\section{Etymology}

The species epithet is derived from the feminine singular noun of the biblical name "Nephilim", the giants who were seen by the twelve people sent by Moses to scout the Land of Canaan. It refers to the large size of the spider. Noun in apposition. 

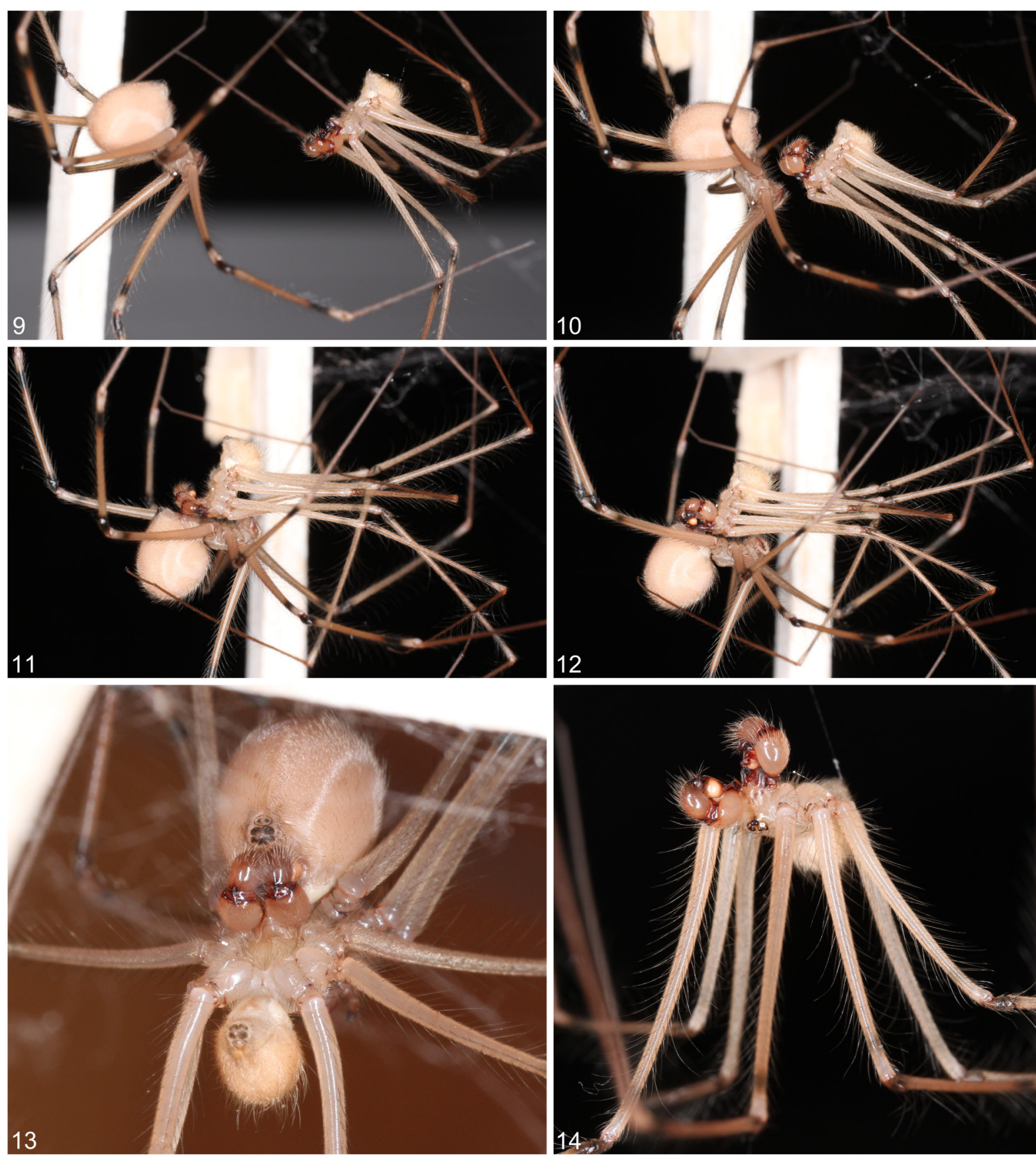

Figs 9-14. Mating sequence of Artema nephilit sp. nov. 9. Male (on the right) approaches female and touches female legs. 10. Male lowers palps below body for final approach. 11. Male searches for correct position on female, female abdomen is pushed backwards. 12. Male rotates palps into final mating position $\left(180^{\circ}\right.$ around longitudinal axis; note that the bulb is visible). 13. Asymmetric insertion of palps (note that the male's left palp is more deeply inserted than the right palp). 14. Male cleans palps. Photos BAH. 

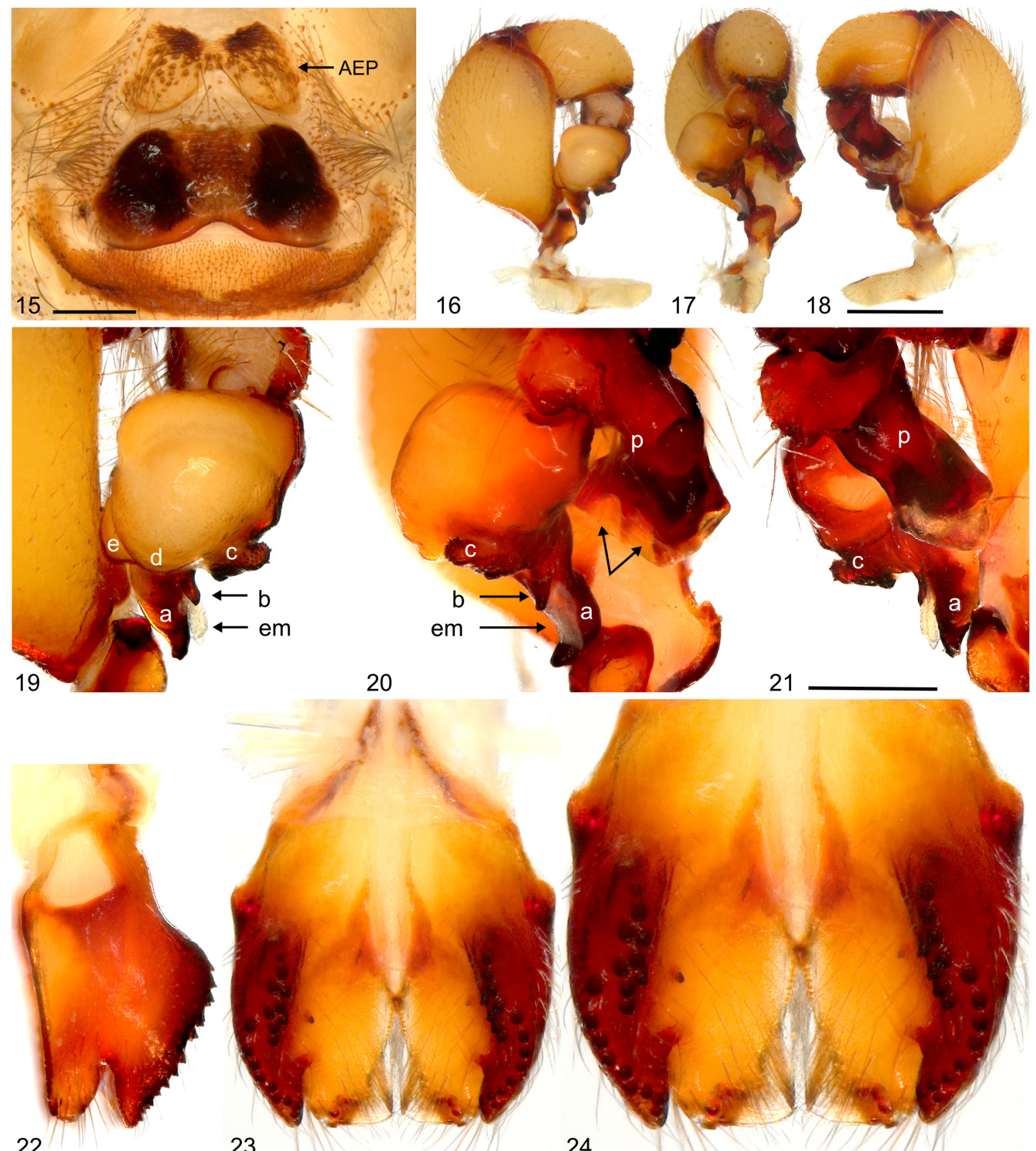

23

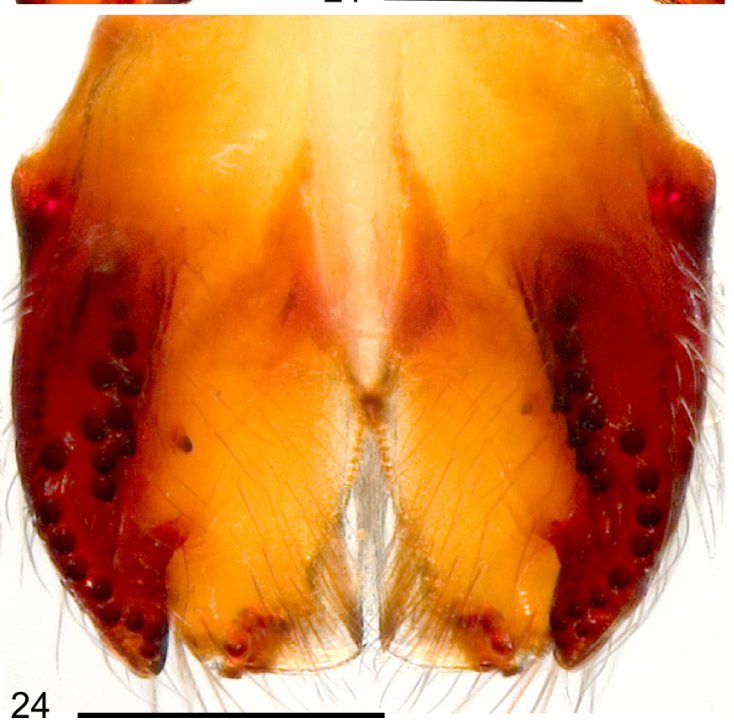

Figs 15-24. Artema atlanta. 15. Epigynum (MRAC 215041, Benin). 16-18. Male left pedipalp (MRAC 120766, Sudan), prolateral, dorsal, and retrolateral views. 19-21. Male left bulb and procursus, prolateral, dorsal, and retrolateral views, arrows in Fig. 20 show notches on distal margin of procursus. 22-24. Male chelicerae (same specimen), lateral and frontal views. Scale lines: 15, 19-24 = $0.5 \mathrm{~mm}$; $16-18=1 \mathrm{~mm}$. 


\section{Material examined}

\section{Holotype}

ISRAEL: ${ }^{\lambda}$, Northern District, Jordan Rift Valley, Mount Berniki, south Teverya (Tiberias) $\left(32.777^{\circ} \mathrm{N}\right.$, $35.541^{\circ}$ E), in cave, -120 m b.s.1., 16 Sep. 2013, B.A. Huber, S. Aharon and E. Gavish-Regev leg. (HUJ Ara 16000).

\section{Other material}

ISRAEL: 3 ㅇ, 1 juv. together with holotype, same data (HUJ Ara 15996-99); 1 $\hat{0}, 1$, , same data but deep in cave (ZFMK Ar 15218-19); 1 q (HUJ Ara 16001), 1 juv. (HUJ Ara 16002), same data; 1 , HaTanur Waterfall, near Metula $\left(33.269^{\circ}\right.$ N, 35.581 ${ }^{\circ}$ E), 15 Mar. 2011, L. Friedman leg. (CSZ);

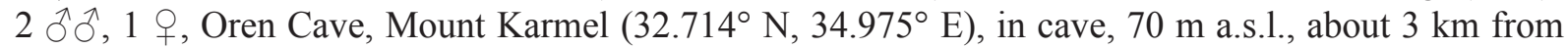
Mediterranean Sea, 17 Sep. 2013, B.A. Huber, E. Gavish-Regev and S. Aharon leg. (ZFMK Ar 1522526); 1 ô, 1 q, 1 juv., En Perat, Nahal Perat $\left(31.833^{\circ} \mathrm{N}, 35.303^{\circ} \mathrm{E}\right)$, in caves and a building, $260-300 \mathrm{~m}$ a.s.1., 15 Sep. 2013, B.A. Huber, S. Aharon and E. Gavish-Regev (ZFMK Ar 15220-21); 1 q, 1 juv., in pure ethanol, same data (ZFMK Isr 51); 1 ㅇ, Ein ad-Duyuk, near Jericho $\left(31.895^{\circ} \mathrm{N}, 35.421^{\circ} \mathrm{E}\right), 25$ May 1983, P. Amitai leg. (HUJ Ara 16003); 8 juvs, Qumeran Cave $\left(31.741^{\circ}\right.$ N, $35.459^{\circ}$ E), 7 Nov. 2012, L. Friedman leg. (SMNH); 1 + , in pure ethanol, Nahal Dawid, En Gedi $\left(31.470^{\circ} \mathrm{N}, 35.390^{\circ} \mathrm{E}\right)$, among
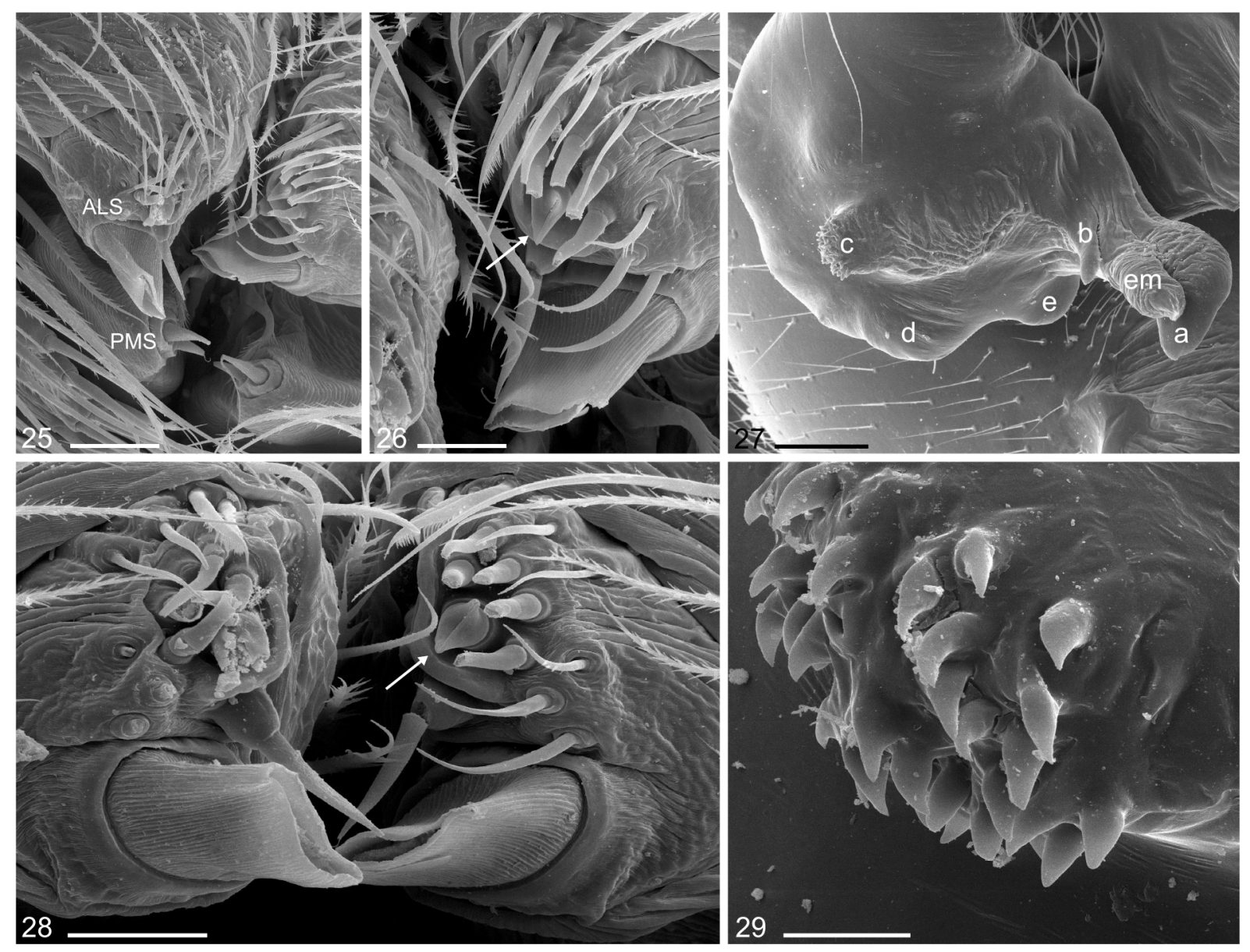

Figs 25-29. Artema atlanta Walckenaer, 1837, ZFMK Gui 82 and ZFMK Gui 111. 25-26, 28. Male ALS and PMS (arrows: one of the six small cylindrically-shaped spigots wider than others). 27. Male left bulb, prolateral-distal view. 29. Small teeth prolaterally on round end of process c. Scale lines: $25=$ $0.06 \mathrm{~mm} ; 26,29=0.03 \mathrm{~mm} ; 27=0.2 \mathrm{~mm} ; 28=0.04 \mathrm{~mm}$. 
rocks, -250 to $-300 \mathrm{~m}$ b.s.1., 10 Sep. 2013, B.A. Huber, S. Aharon and E. Gavish-Regev leg. (ZFMK

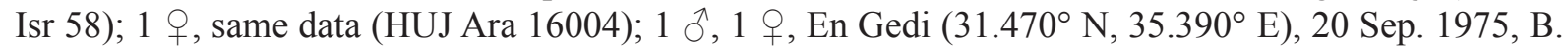
Feldman leg. (HUJ Ara 16005-6); 1 juv., same locality, 29 May 1968, P. Amitai leg. (HUJ Ara 16007); 1 ㅇ, in pure ethanol, Ma'ale Ya'ir $\left(31.215^{\circ} \mathrm{N}, 35.359^{\circ} \mathrm{E}\right)$, under large rocks, $-370 \mathrm{~m}$ b.s.l., 9 Sep. 2013 , B.A. Huber, S. Aharon and E. Gavish-Regev (ZFMK Isr 49); 2 우, Nahal Temarim $\left(31.640^{\circ} \mathrm{N}\right.$, $35.411^{\circ}$ E), under large rocks, 3 Sep. 2013, S. Aharon leg. (HUJ Ara 16008-9); 2 q $q$, 1 juv., Sedom

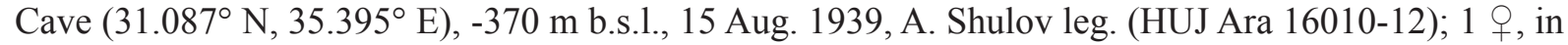
pure ethanol, same locality, 10 Sep. 2013, B.A. Huber, S. Aharon and E. Gavish-Regev (ZFMK Isr 47); $1 \hat{\jmath}$ (HUJ Ara 16013), 1 q (ZFMK Ar 15222), same data; 2 우, same locality, 30 Oct. 1941 (CSZ); 3 juvs, Sedom Spring, 15 Aug. 1957, H. Ginsburg leg. (HUJ Ara 16014-16); 3 우, Arubotaim Cave

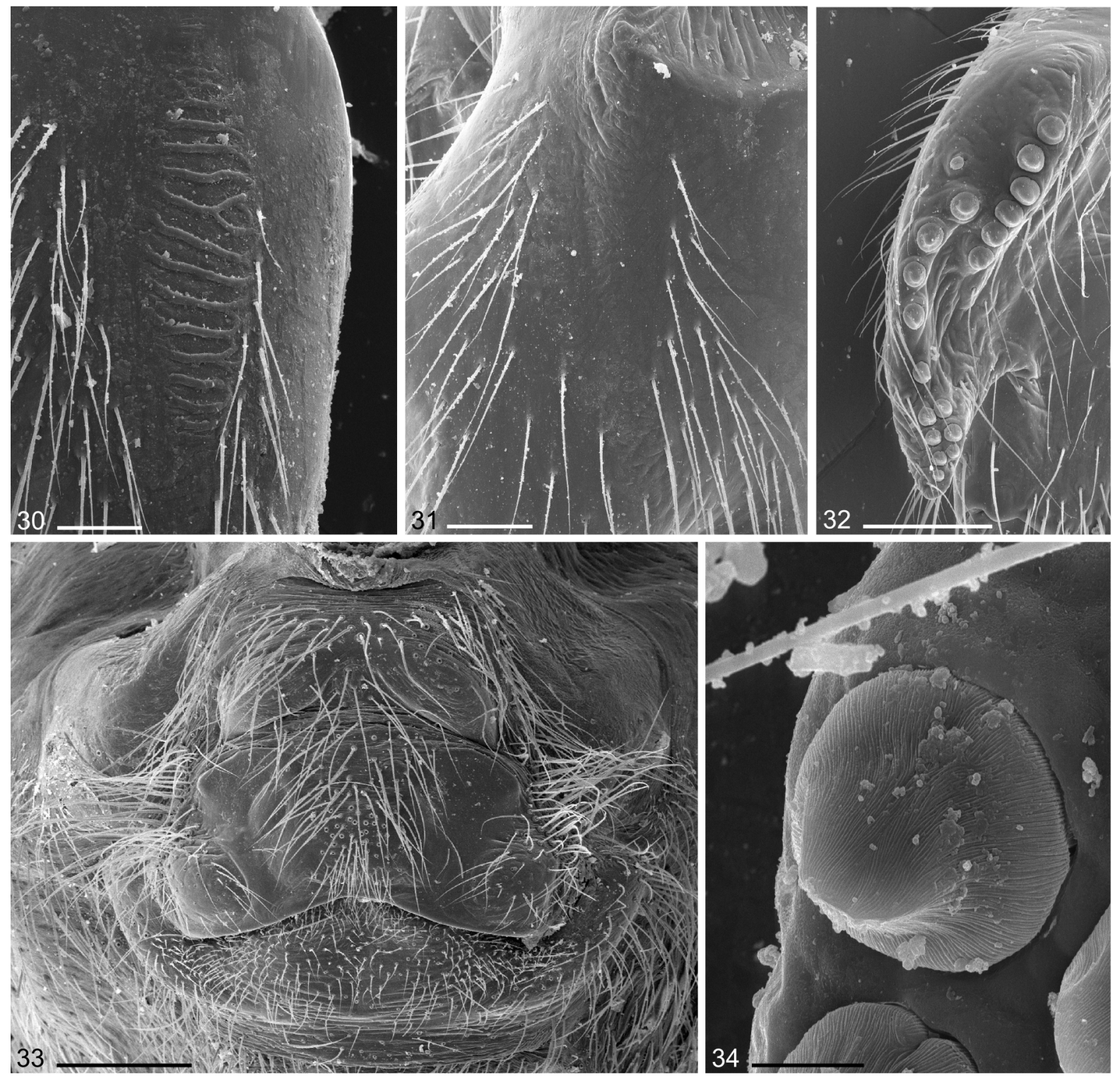

Figs 30-34. Artema atlanta Walckenaer, 1837, ZFMK Ar 15217 () and ZFMK Gui $82(ð)$. 30. Female stridulatory ridges. 31. Absence of male stridulatory ridges. 32. Male chelicerae with frontal row of modified (cone-shaped) hairs. 33. Epigynal plate. 34. Modified (cone-shaped) hair on chelicerae process. Scale lines: $30-31=0.1 \mathrm{~mm} ; 32=0.2 \mathrm{~mm} ; 33=0.6 \mathrm{~mm} ; 34=0.01 \mathrm{~mm}$. 
$\left(31.101^{\circ}\right.$ N, $35.390^{\circ}$ E), -380 m b.s.1., 10 Sep. 2013, B.A. Huber, S. Aharon and E. Gavish-Regev leg. (ZFMK Ar 15223); 1 ㅇ, 2 juvs, in pure ethanol (ZFMK Isr 46), 1 juv. (HUJ Ara 16017), same data; 1 , Malham Cave (31.076 ${ }^{\circ}$ N, 35.397 ${ }^{\circ}$ E), -370 m b.s.l., 10 Sep. 2013, B.A. Huber, S. Aharon and E. GavishRegev leg. (HUJ Ara 16018); 1 क (ZFMK Isr 44), 1 juv. (HUJ 16038), in pure ethanol, same data; 1 , NW of 'En Tamar, Nahal Zin ( $30.989^{\circ}$ N, 35.346 ${ }^{\circ}$ E), in crevices, $-340 \mathrm{~m}$ b.s.l., 9 Sep. 2013, S. Aharon, E. Gavish-Regev and B.A. Huber leg. (HUJ Ara 16019); 1 §, molted to adult 30 Oct. 2013, NW of 'En
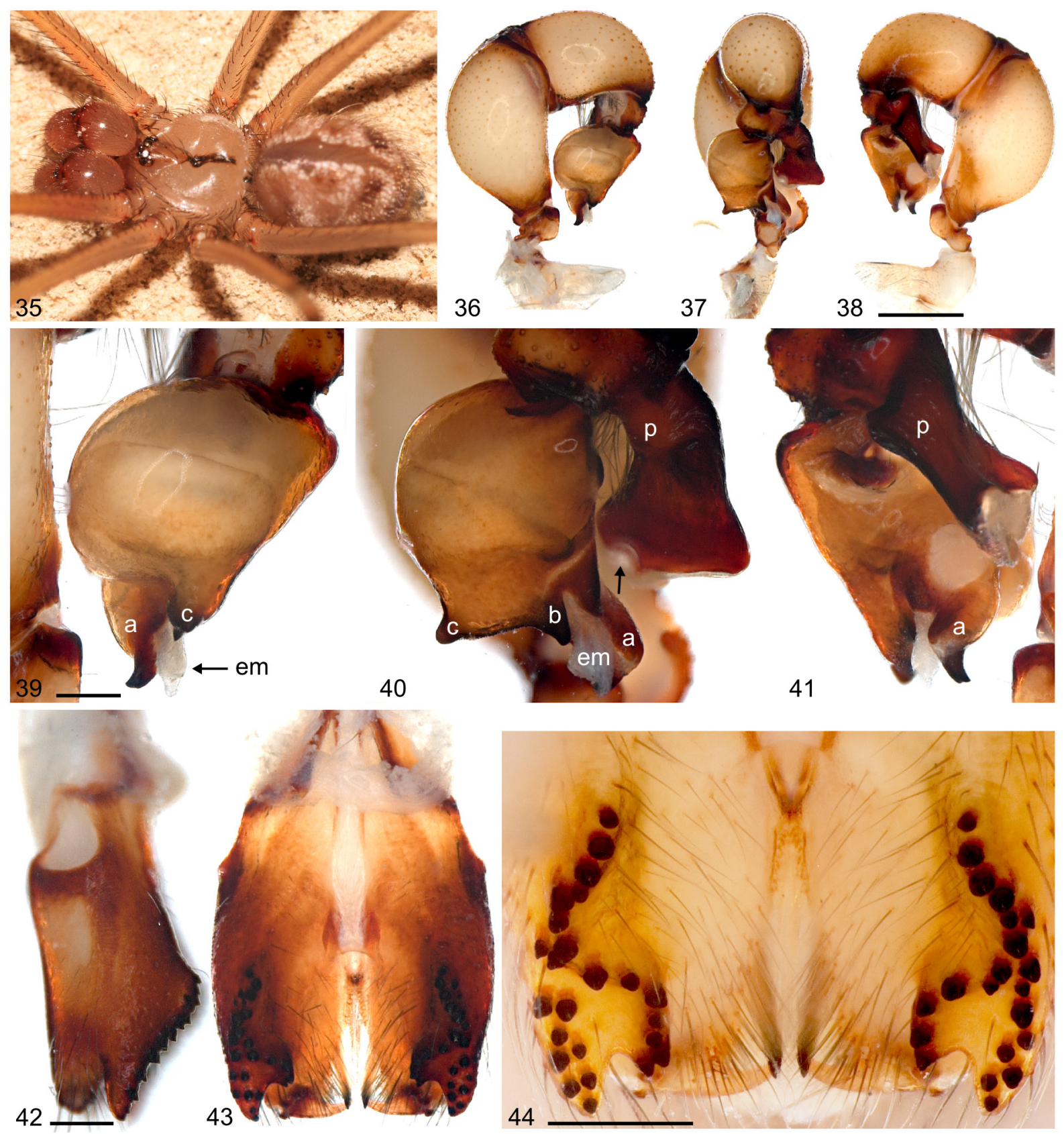

Figs 35-44. Artema nephilit sp. nov. 35. Male habitus (ZFMK Ar 15225, Israel, Mount Karmel, Oren Cave). 36-38. Male left pedipalp (ZFMK Ar 15227, Jordan, Petra): prolateral, dorsal, and retrolateral views. 39-41. Male left bulb and procursus: prolateral, dorsal, and retrolateral views. 42-44. Male chelicerae (ZFMK Ar 15227, Jordan, Petra and HUJ Ara 16000, Israel, Mount Berniki): lateral and frontal views. Scale lines: $36-38,42-43=1 \mathrm{~mm} ; 39-41,44=0.25 \mathrm{~mm}$. 
Tamar, Nahal Zin $\left(30.991^{\circ} \mathrm{N}, 35.347^{\circ} \mathrm{E}\right)$, in tube near road tunnel, $-340 \mathrm{~m}$ b.s.1., 9 Sep. 2013, B.A. Huber, S. Aharon and E. Gavish-Regev leg. (ZFMK Ar 15224); 1 q, Ramat Avedat, near Sede Boqer,

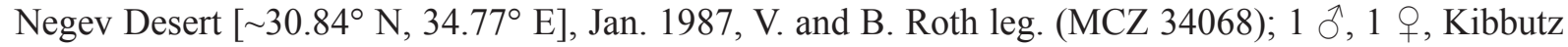
Samar $\left(29.831^{\circ} \mathrm{N}, 35.022^{\circ} \mathrm{E}\right)$, dumping ground, $100 \mathrm{~m}$ a.s.l., $11 \mathrm{Sep} .2013$, S. Aharon, E. Gavish-Regev and B.A. Huber leg. (HUJ Ara 16020-21); 1 , in pure ethanol, same locality, 19 Oct. 2013, E. Gavish-

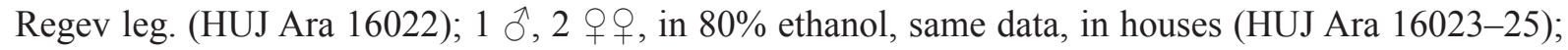

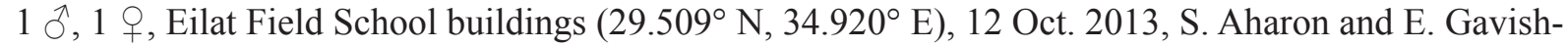
Regev leg. (HUJ Ara 16026-27); 2 juvs, in pure ethanol, same data (HUJ Ara 16028-29).

GREECE: 1 \% , Athens, Acropolis [37.97 $\left.{ }^{\circ} \mathrm{N}, 23.72^{\circ} \mathrm{E}\right]$, collection Roewer, date and collector not given (SMF RII/3724).

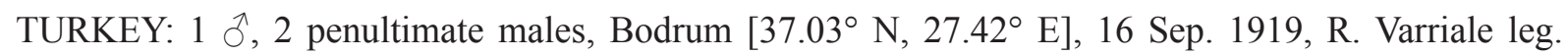

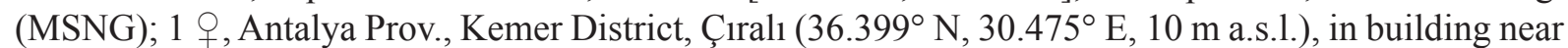
beach, 3 Aug. 2016, B.A. Huber leg. (ZFMK, collected as juvenile, molted to adult in Jul. 2017, still alive as of Nov. 2017).
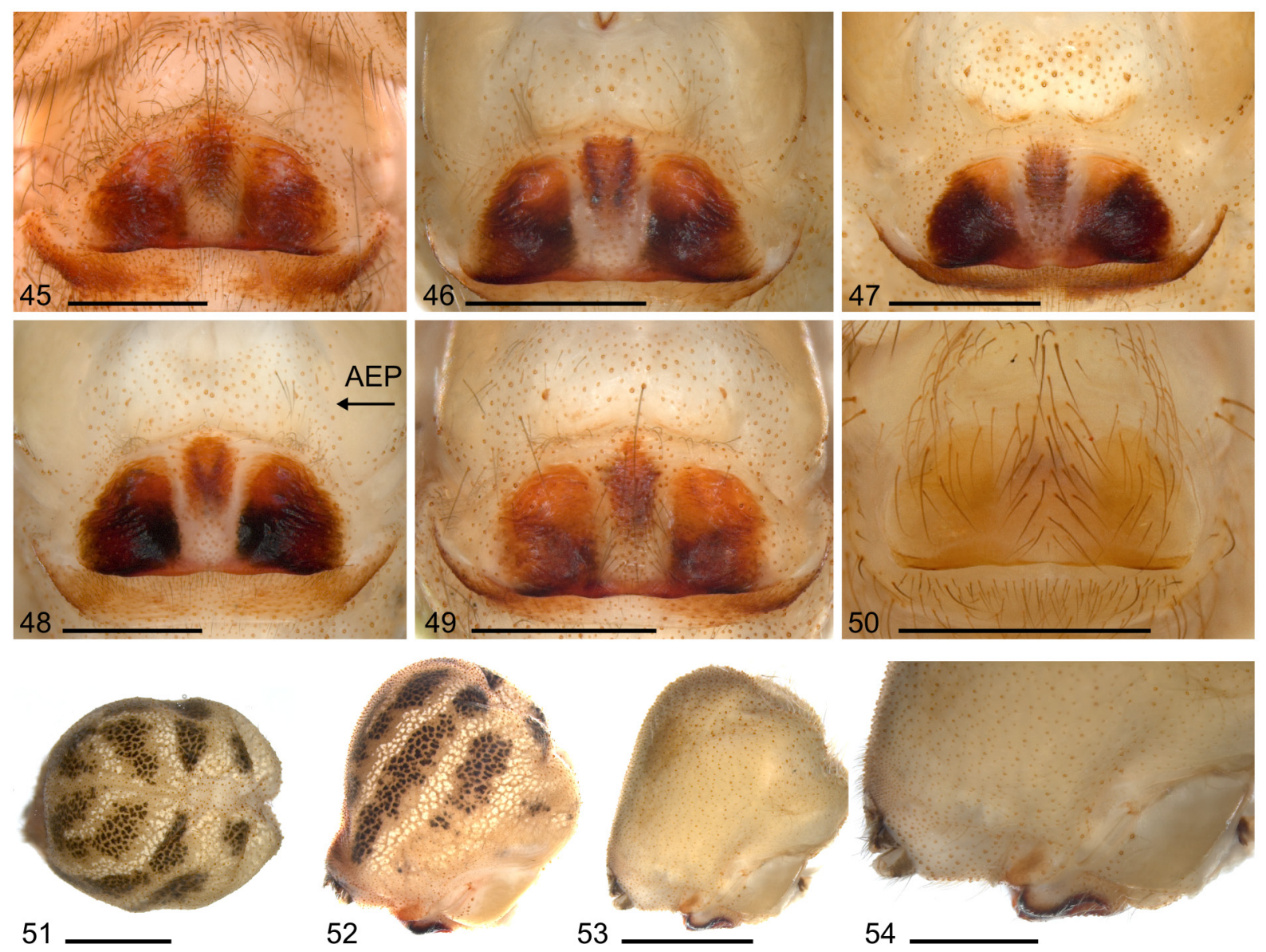

Figs 45-54. Artema nephilit sp. nov. 45-50. Epigyna, ventral views, females from Berniki caves (45, 49: HUJ Ara 15996-7),'En Tamar (46: HUJ Ara 16019), Samar (47: HUJ Ara 16020), Petra (48: ZFMK Ar 15227) and HaTanur Waterfall (50: CSZ). 51-54. Female abdomens, dorsal and lateral views, from Petra (51-52: ZFMK Ar 15227), and 'En Tamar (53-54: HUJ Ara 16019). Figs 45-47, 49-50, 53-54 Israel; 48, 51-52 Jordan. Scale lines: 45-50, $54=1 \mathrm{~mm} ; 51-53=2 \mathrm{~mm}$. 


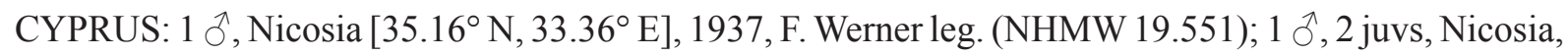
near Agios Sozomenos (35.059 $\left.\mathrm{N}, 33.421^{\circ} \mathrm{E}\right), 180 \mathrm{~m}$ a.s.l., in cave, 5 Jul. 2016, M. Hadjiconstantis leg. $(\mathrm{CMH}) ; 1$ ㄱ, 2 우우, same data but 20 Jan. $2016(\mathrm{CMH}) ; 3$ 우, Nicosia, Geri (35.102 $\left.{ }^{\circ} \mathrm{N}, 33.417^{\circ} \mathrm{E}\right)$, $150 \mathrm{~m}$ a.s.1., in house, 15 Sep. 2016, M. Hadjiconstantis leg. (CMH); 1 o, 2 juvs, Famagusta, Lisi, $\left(35.106^{\circ} \mathrm{N}, 33.680^{\circ}\right.$ E), $60 \mathrm{~m}$ a.s.l., in Panagia Lysis church, 15 Apr. 2016, M. Hadjiconstantis leg. $(\mathrm{CMH})$.

JORDAN: Aqaba Province: $2 \widehat{o}^{\widehat{o}}$, Wadi Rām $\left(29.7405^{\circ} \mathrm{N}, 35.4574^{\circ} \mathrm{E}\right)$, among rocks, $830 \mathrm{~m}$ a.s.1., 12 Sep. 2013, B.A. Huber leg. (ZFMK Ar 16161-62), collected as juveniles, molted to adults in

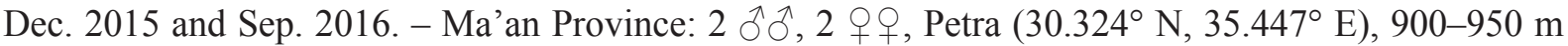
a.s.l., rock-cut tombs, near theater, 13 Sep. 2013, B.A. Huber leg. (ZFMK Ar 15227); 1 o, 1 juv., in pure ethanol, same data (ZFMK Isr 36); 1 $\hat{\sigma}$, same data but among rocks (ZFMK Ar 15228). - Karak Province: 1 o, 1 juv., Wadi Hasa $\left(31.004^{\circ}-31.014^{\circ} \mathrm{N}, 35.494-35.506^{\circ} \mathrm{E}\right),-330$ to $-250 \mathrm{~m}$ b.s.l., among rocks, 14 Sep. 2013, B.A. Huber leg. (ZFMK Ar 15229-30); 1 q, in pure ethanol, same data (ZFMK Isr

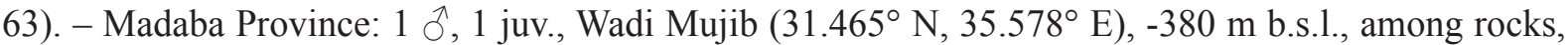
14 Sep. 2013, B.A. Huber leg. ZFMK (Ar 15231).

Material assigned tentatively (see Notes below)

YEMEN: 1 ㅇ, "Yar Ju Amlah" [= Al Ja'milah?, 17.11 N, 43.56 E], 1950, M. Borri and M. Poggesi leg. (MZUF 128).

UNITED ARAB EMIRATES: 1 q, Near Ra's al-Khaimah $\left(25.46^{\circ} \mathrm{N}, 55.96^{\circ} \mathrm{E}\right)$, hand-collected, 8 Mar. 2005, A. van Harten leg. (ZFMK Ar 15232).

\section{Description}

\section{Male (holotype)}

MeAsurements. Total body length 7.0, carapace width 3.1. Leg 1: $48.4(11.9+1.4+13.9+18.3+2.9)$, tibia 2: 10.2, tibia 3: 8.0, tibia 4: 10.9; tibia $1 \mathrm{~L} / \mathrm{d}: 35$. Distance PME-PME $190 \mu \mathrm{m}$, diameter PME 190 $\mu \mathrm{m}$, distance PME-ALE $90 \mu \mathrm{m}$, distance AME-AME $50 \mu \mathrm{m}$, diameter AME $170 \mu \mathrm{m}$.

CoLor. Carapace pale to light beige, with dark gray median band. Clypeus with wide light brown band (as in Figs 4, 9-14, 35). Legs pale yellow to light ochre with dark rings on femora subdistally, patellae + tibiae proximally, and tibiae subdistally, tips of femora and tibiae whitish; sternum pale, with narrow light brown margins. Abdomen light brown with white and dark dots forming stripes from dorsal to lateral side (as in Figs 51-52).

BoDy. Ocular area slightly elevated. Carapace with median pit and distinctive posterior furrow. Clypeus unmodified. Sternum wider than long (2.3/1.5). Chelicerae as in Figs 42-44 and as in Figs 67-69, with frontal row of $\sim 20$ modified (cone-shaped) hairs on each side that splits distally, with outer branch ending at tip of process, inner branch ending at tip of median projection; with indistinct small field of stridulatory ridges laterally (as in Fig. 70). Abdomen globose and high; gonopore with four epiandrous spigots.

PALPS. As in Figs 36-38. Coxa unmodified. Trochanter with short ventral projection. Femur with short, somewhat pointed retrolateral process proximally; ventral membranous area proximally bordered on both sides by sclerotized ridges; femur-patella hinges close together dorsally. Patella very short. Procursus with proximal dorsal process and weakly developed ventral pocket; with distal dorsal notch on prolateral margin (as in Fig. 40). Bulb with two processes close to membranous embolus (processes a and b, as in Fig. 40), process c (as in Fig. 40) strongly projecting prolaterally, and indistinct projection on ventral side of bulb (as in Figs 39, 64-65). Area between processes $b$ and $c$ modified with granular surface (as in Fig. 66). 
LEGS. Without spines; with long curved hairs, especially on tibiae and metatarsi; retrolateral trichobothrium on tibia 1 at $8 \%$; prolateral trichobothrium present on all tibiae; pseudosegmentation not visible.

Male (variation)

Tibia 1 in 14 other males: 9.2-20.6 (mean 14.4). Color pattern on abdomen varies from distinctive stripes consisting of black and white dots on pale to brown-ochre background to pale without any pattern (cf. females, Figs 52-53); leg color varies from light brown to ochre; ocular area usually light brown to ochre; median band on carapace sometimes reaches posterior margin of ocular area, forming short
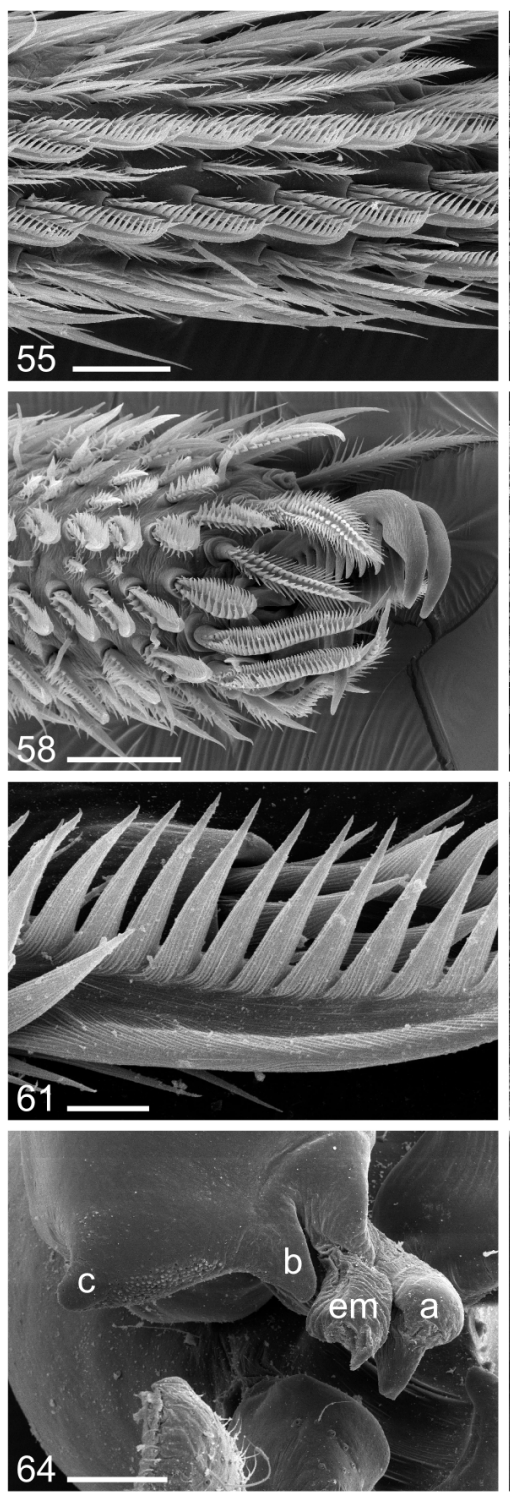
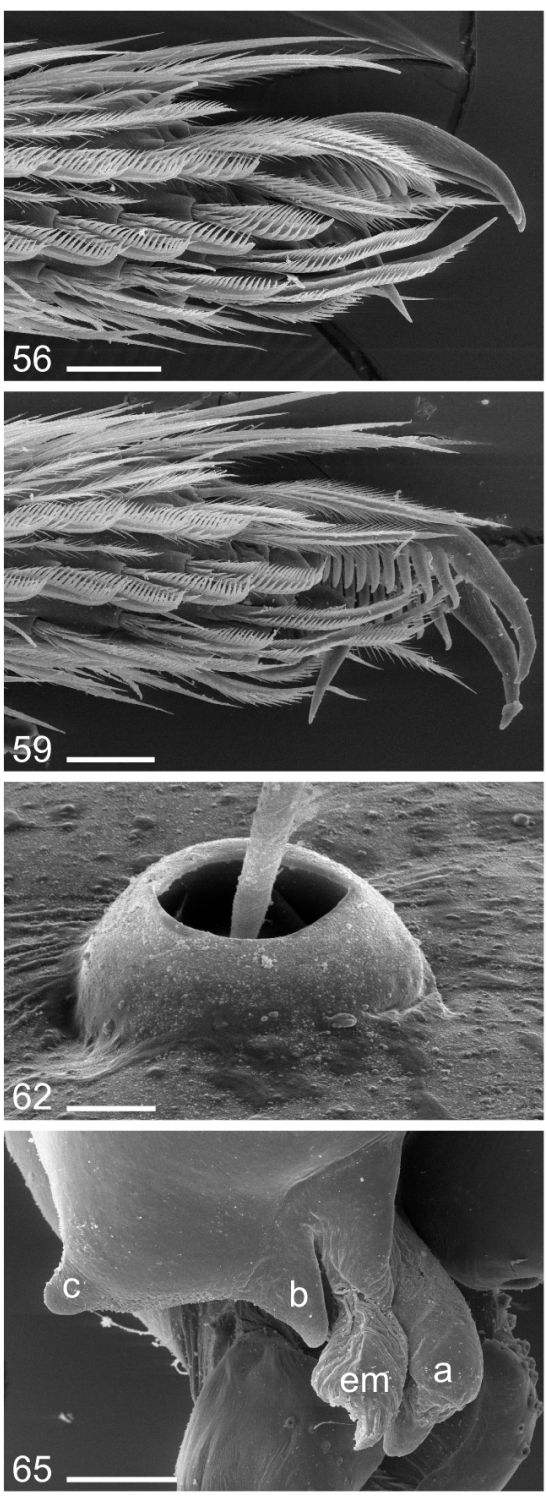
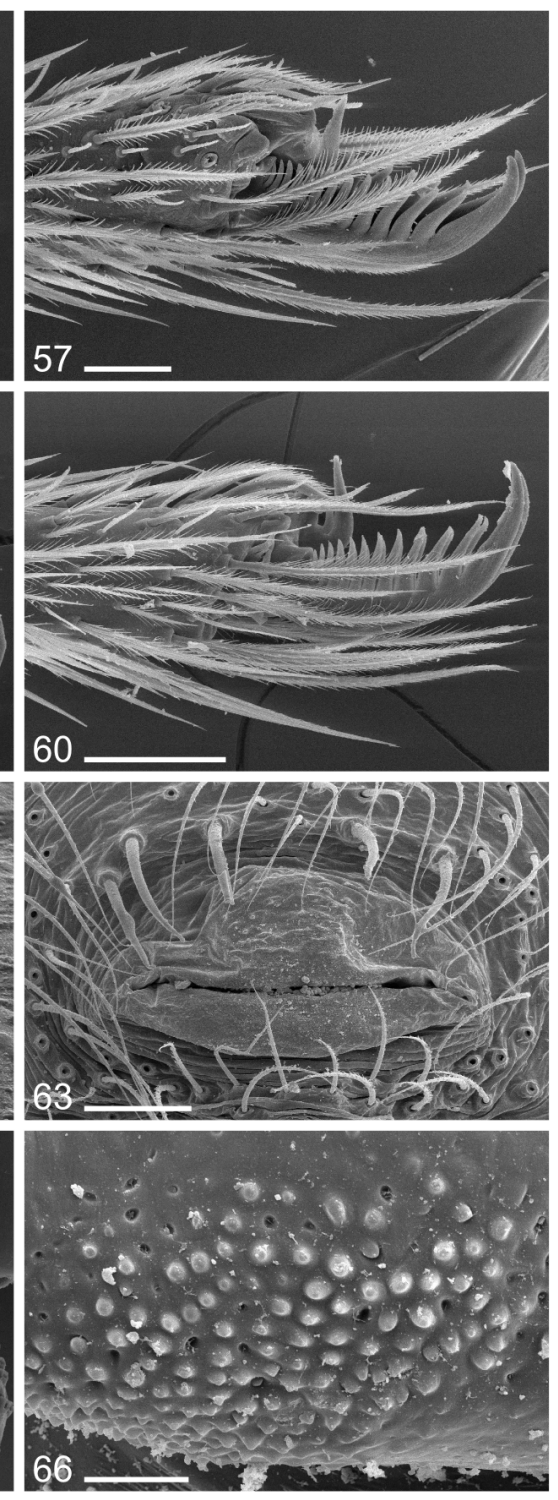

Figs 55-66. Artema nephilit sp. nov., ZFMK Ar 15225-27 (ð) and HUJ Ara 15997 (†). 55-56. Combhairs on left male tarsus 4 , prolateral views. 57. Right male tarsus 2 , showing absence of comb-hairs. 58-59. Comb-hairs on left female tarsus 4 , prolateral (-distal) views. 60. Right female tarsus 2 , showing absence of comb-hairs. 61. Detail of male comb-hair on tarsus 4. 62. Trichobothrium base, female palpal tibia. 63. Male gonopore and epiandrous spigots. 64-65. Male bulbal processes. 66. Modified area between processes $\mathrm{b}$ and $\mathrm{c}$ on male genital bulb. Scale lines: $55,58=0.08 \mathrm{~mm} ; 56-57,59,63=0.1 \mathrm{~mm}$; $60,64-65=0.2 \mathrm{~mm} ; 61-62=0.01 \mathrm{~mm} ; 66=0.03 \mathrm{~mm}$. 

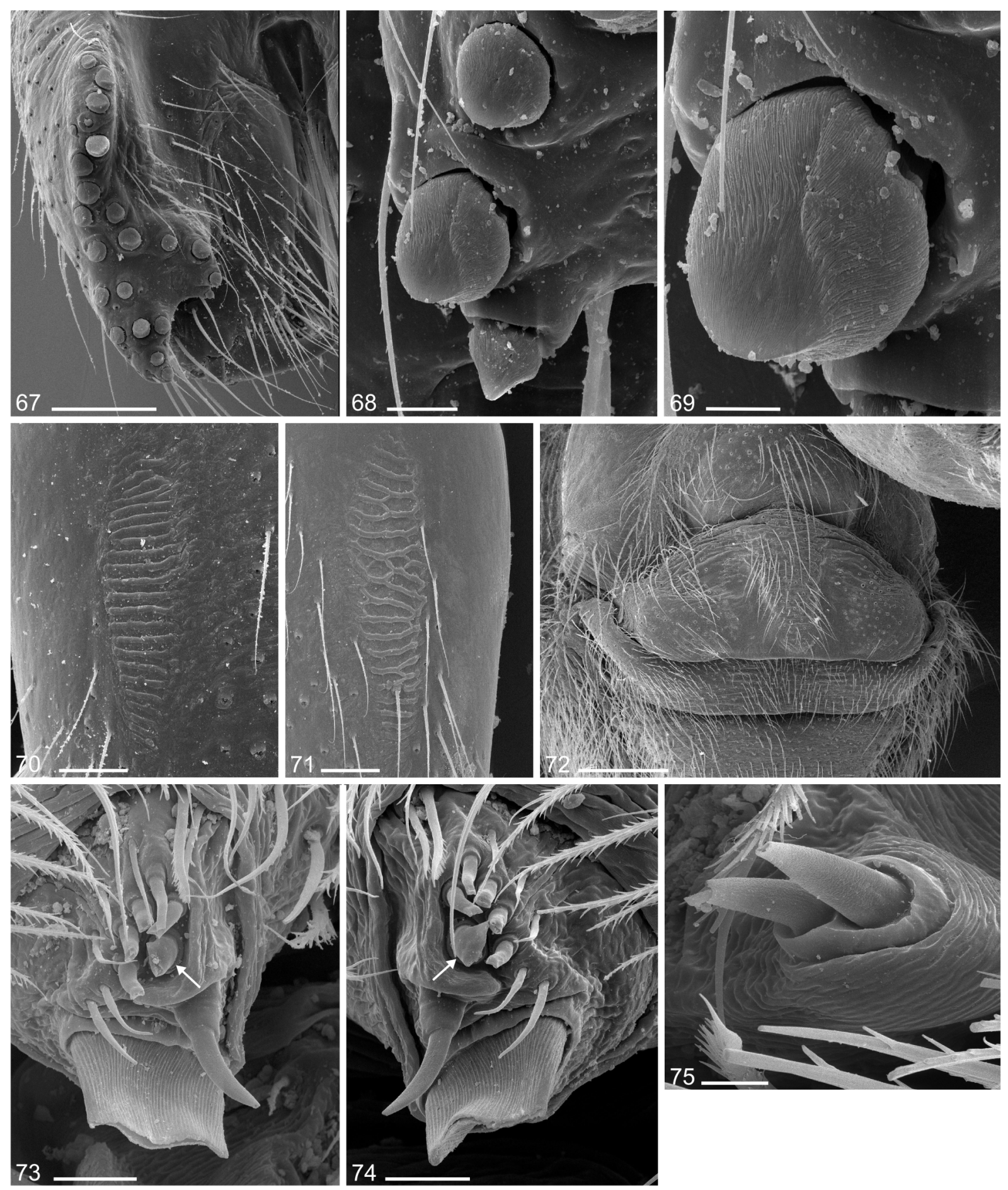

Figs 67-75. Artema nephilit sp. nov., ZFMK Ar 15225-27 (ð) and HUJ Ara 15997 (). 67-69. Male chelicerae with frontal row of modified (cone-shaped) hairs that split distally. 70. Male stridulatory ridges. 71. Female stridulatory ridges. 72. Epigynal plate. 73-74. Female ALS (arrows: one of the six small piriform spigots wider than others). 75. Female PMS. Scale lines: $67=0.2 \mathrm{~mm} ; 68,75=0.02 \mathrm{~mm}$; $69=0.01 \mathrm{~mm} ; 70=0.08 \mathrm{~mm} ; 71=0.1 \mathrm{~mm} ; 72=0.6 \mathrm{~mm} ; 73-74=0.04 \mathrm{~mm}$. 
v-shaped mark. Cheliceral modified hairs vary slightly in numbers. Gonopore with variable number of epiandrous spigots (4-6) (Fig. 63).

\section{Female}

In general similar to male; tibia 1 in 26 females: 8.0-16.5 (mean 12.5); several females with light brown carapace margins and subtle brown stripes on ocular area. Stridulatory files laterally on chelicerae more distinct than in males (Fig. 71). Epigynum almost twice as wide as long, semi-circular, posterior margin almost straight, gently undulating; epigynal plate consisting of two sclerotized lateral areas that appear swollen posteriorly, pale median area, and dark median sclerite anteriorly (variably large and variably distinct) (Figs 45-50); pair of projections anterior to epigynum (AEP) visible (Fig. 48) but not prominent as in A. bunkpurugu (cf. Huber \& Kwapong 2013: figs 49, 53-54).

\section{Natural history}

The spiders were found both in natural habitats such as caves, deep crevices, and under boulders, as well as in man-made habitats such as buildings, under low culverts, and artificial caves. In caves, the spiders built irregular webs (not clearly dome-shaped webs) near the ground, under stones, in crevices, and on the cave ceiling. The spiders seemed to avoid the deeper, dark parts of the visited caves. In a large cave survey we conducted in Israel (Aharon 2016), we found A. nephilit sp. nov. in caves especially along the Jordan Rift Valley, in a very hot and arid zone with low mean annual precipitation (50-150 mm). Only a few specimens were found outside the Jordan Rift Valley, in caves in areas with higher mean annual precipitation $(400-650 \mathrm{~mm})$ in a more mesic habitat. These findings suggest that the species is more abundant in xeric, hot and dry caves rather than in humid caves nearby. The spiders were always found on the east or south slopes that are dryer than the west and north slopes and thus seem to be adapted to arid conditions (Aharon 2016).

We examined more than 40 caves in Israel; 19 caves were inhabited by $A$. nephilit sp. nov., and most of these caves were dry. Some specimens were also found in hot, humid caves, but the species was never found in wet caves. In caves in southern Israel, where food abundance was low, we could not observe prey items. In a cave situated in the Golan Heights, in the north of Israel, where the annual precipitation is higher, we recorded remnants of isopods, tenebrionid beetles, small scorpions, and a spider. In the south of Israel, in a basement of the Eilat Field School, we observed remnants of adult males that had probably been killed by females (that were seen nearby), while in a cave in Nahal Perat, east of Jerusalem, we observed the predation of an adult male A. nephilit sp. nov. by Holocnemus pluchei (Scopoli, 1763). Penultimate instar juveniles collected from caves in southern Israel (Arubatayim, Sedom, and Malcham) and reared independently in Bonn, Germany and Midreshet Ben-Gurion, Israel, molted to adult almost

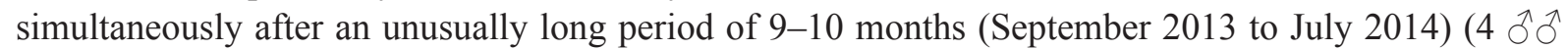
and 1 + molted in Midreshet Ben-Gurion; $3 \hat{\partial} \widehat{\partial}$ in Bonn). This simultaneous timing suggests that the long period is not an artifact caused by the food regime or differences from natural conditions, but rather reflects an intrinsic growth and maturation period.

A mating sequence was observed on 10 Jan. 2015 (in Bonn, Germany). Male from Israel, Sedom Cave; collected penultimate in September 2013; molted to adult in July 2014. Female from Israel, Mount Berenice; collected penultimate in September 2013; molted to adult in September 2014. Previous trials (with various males and females) performed in daylight had resulted in no male reaction when placed into the female's web. Trials under red light resulted in male courtship, but the females, who had not recently fed, attacked the males. Two days after being fed with crickets, the female above finally accepted the male. Time specification shown as hr:min.

0:00 Male is gently transferred to female web. 
0:12 Male approaches female, bounces slightly and touches silk lines with front legs; female directs herself towards male, vibrates slightly a few times.

0:16 Male touches female legs and approaches further (Fig. 9); female remains mostly still.

0:17 Final approach; male lowers palps below body (Fig. 10); searches for about $20 \mathrm{sec}$ for correct position on female, apparently by searching for correct alignment of chelicerae relative to epigynum (Fig. 11); female abdomen is pushed backwards.

0:18 As soon as chelicerae are correctly placed (locked?) at epigynum, palps are rotated $180^{\circ}$ around longitudinal axis (procursus moving outward and forward; Fig. 12); insertion of palps, start of copulation; female releases legs from silk, pulls all legs above body and is moved by male to perpendicular final mating position.

0:19-1:02 No major movements, only very slight jerks of male body, usually every 6-8 seconds, rarely with shorter $(4 \mathrm{sec})$ or longer $(10 \mathrm{sec})$ intervals; no rhythmic palpal movements; no female movements; no female stridulation; asymmetric insertion of palps, consistent over entire copulation (left palp more deeply inserted than right palp; Fig. 13).

1:02 Sudden separation, apparently initiated by male.

1:02-1:12 Female remains motionless; male cleans palps for about $10 \mathrm{~min}$ (Fig. 14), then also motionless.

1:18 End of observation.

About 24 weeks later, this female produced an egg-sac. After another two weeks (i.e., beginning of August 2015), about 40 spiderlings emerged; two weeks later again they molted for the first time. In July 2017, i.e., almost two years after eclosion, most remaining specimens (about 15) molted to adults.

\section{Distribution}

After the ubiquitous Holocnemus pluchei, A. nephilit sp. nov. is the most common pholcid in the Jordan Rift Valley. It has been collected from underground shelters and caves from the Eilat Mountains (Fig. 8) in the south, to Nahal Ayun in the north. Specimens from outside the Rift Valley (Israel: Ramat Avedat near Sede Boqer; Oren Cave (Fig. 7), Mount Karmel; Jordan: Petra), as well as from Cyprus, Greece, and Turkey, indicate that the species is probably widely distributed in the area. Two females with very similar epigynum were collected from Yemen and the United Arab Emirates (Fig. 1).

\section{Notes}

We have not seen the material identified by Bodenheimer (1937) as A. mauriciana. However, A. mauriciana $(=$ A. atlanta) does not seem to occur in Israel and there is no evidence that it ever existed there. We consider it likely that Bodenheimer was dealing with the common $A$. nephilit sp. nov. rather than with the much rarer (i.e., in Israel) $A$. doriae.

The females from Yemen ("Yar Ju Amlah" = Al Ja'milah?) and from the United Arab Emirates have a very similar epigynum, but since no males from these localities are known, they are assigned tentatively.

Artema kochi Kulczyński, 1901 (revalidated)

Figs 1, 76-89, 204, 211

Artema kochii Kulczyński 1901: 19-20; pl. 1, fig. 14. Erroneously synonymized with "Artema mauriciana" by Simon (1908: 426-427).

\section{Misidentifications}

"Pholcus borbonicus" - L. Koch 1875: 25-26; pl. 3, fig. 1, 1a-c (q). — Thorell 1881: 179-180 (in footnote). - Simon 1882: 234.

"Artema mauricia" - Simon 1890: 93. 


\section{Diagnosis}

Males are easily distinguished from known congeners by their bulbal process b (Fig. 81), flattened and rectangular distally, rather than pointed or awl-shaped as in congeners; processes $\mathrm{c}, \mathrm{d}$, and e absent (process $\mathrm{c}$ present in all congeners, except Artema sp. $\mathrm{b}$ from Algeria). Males differ also by their cheliceral processes that are strongly projecting proximally with frontal rows of modified hairs; with several cone-shaped, sclerotized processes situated frontally near median line (arrows in Figs 83, 85). Females differ from known congeners by entirely different shapes of anterior epigynal projections (AEP) and epigynal plate (Figs 86, 88): anterior epigynal projections sclerotized and elongated (in contrast to all congeners), not projecting (in contrast to A. bunkpurugu); epigynal plate sclerotized, wide rectangular, with triangular anterior projection between AEP, median posterior margin gently protruding.

\section{Material examined}

Neotype (designated herein)

ERITREA: 1 ô, "Massaua" [= Massawa, $15.61^{\circ} \mathrm{N}, 39.45^{\circ}$ E], Apr. 1870, A. Yssel leg. (MSNG), examined (see Notes below).

\section{Other material}

ERITREA: 1 q, 7 juvs, together with neotype, same data.

YEMEN-ERITREA: 2 ふึ, 2 우, 4 juvs, Aden/Massawa [1889] (E. Simon, “393” part) (MNHN AR 10169 part).
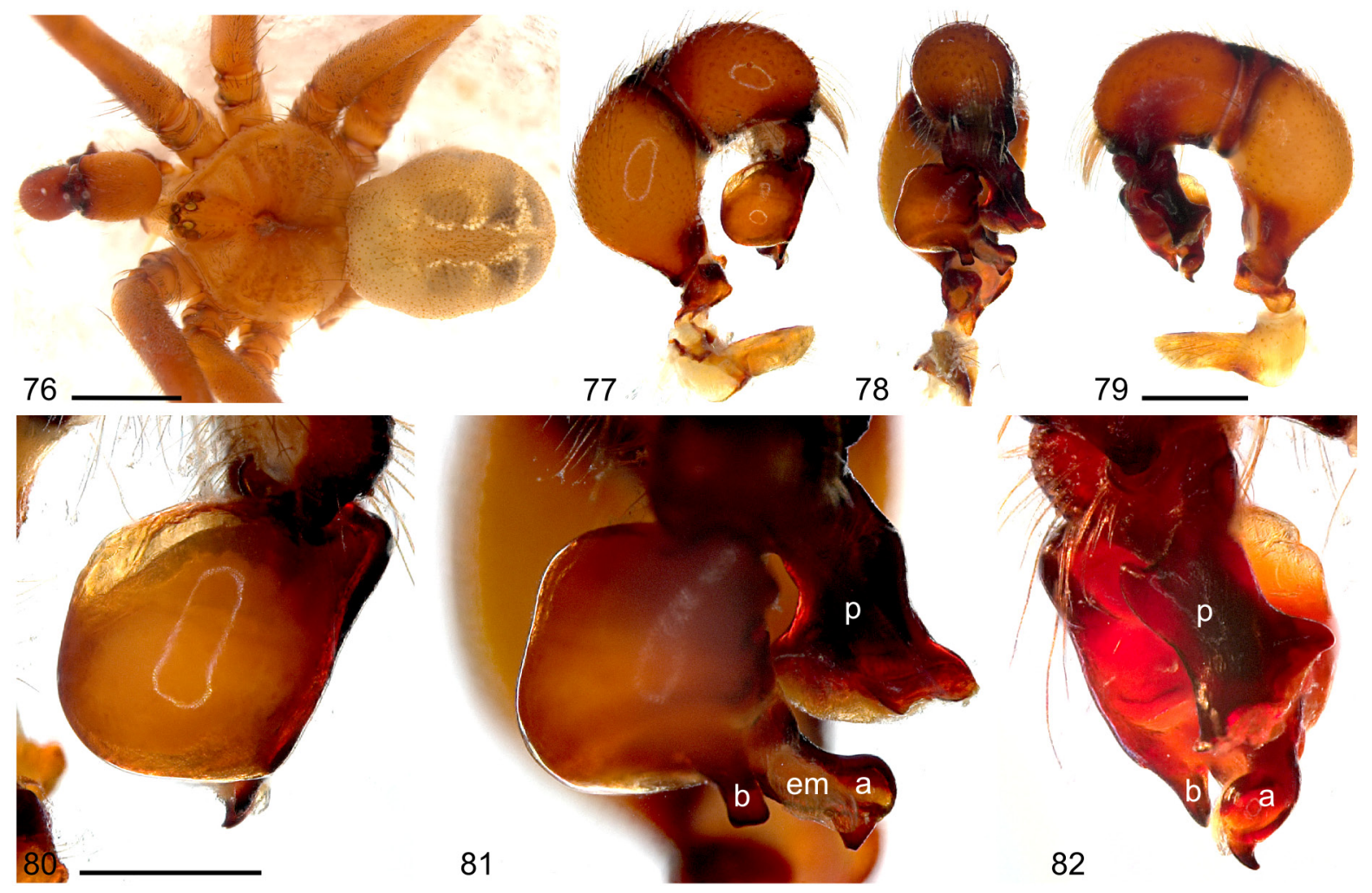

Figs 76-82. Artema kochi Kulczyński, 1901 (MNHN AR 10169 part, Yemen-Eritrea). 76. Male habitus. 77-79. Male left pedipalp: prolateral, dorsal, and retrolateral views. 80-82. Male left bulb and procursus: prolateral, dorsal, and retrolateral views. Scale lines: $76=2 \mathrm{~mm} ; 77-79=1 \mathrm{~mm} ; 80-82=0.5 \mathrm{~mm}$. 
YEMEN: 1 \%, 3 juvs, "Sceik Osman" [= Shaykh Uthman, Aden, $12.86^{\circ} \mathrm{N}, 44.98^{\circ}$ E], Jan. 1880, Doria and Beccari leg. (this is the material cited in Simon 1882 as Pholcus borbonicus) (MSNG); 1 \%, Aden $\left[12.81^{\circ} \mathrm{N}, 45.03^{\circ} \mathrm{E}\right]$, date not given, E.A. Emerton leg. (MCZ 34048); 1 §, 1 juv., same locality, 15 Oct. 1938, collector not given (NHMW 353).

SUDAN: 1 ภ, New Halfa [15.32 N, 35.60 E], 450 m a.s.1., Jun. 2013, M. Siyam leg. (ZMB).

ETHIOPIA: 1 q, “Abyssinia, Didi Davvs" (uncertain spelling), 20-26 Jun. 1920, B. Brown leg. (AMNH).

Localities not clear: $1 \hat{\jmath}$, “Urso 1283", date not given, Kovacs leg. (MZUF); $1 \hat{\partial}$, “Afrique Orientale, Gibdo" [= Djibouti/Eritrea?], Apr.-May 1907, Katona leg. (MZUF).

\section{Description}

Male (MNHN Ar 10169)

MEASUREMENTS. Total body length 6.8 , carapace width 3.5. Leg 1: $46.2(12.1+1.6+13.4+16.2+2.9)$, tibia 2: 10.0, tibia 3: 7.6, tibia 4: 10.5; tibia $1 \mathrm{~L} / \mathrm{d}$ : 34. Distance PME-PME $190 \mu \mathrm{m}$, diameter PME $190 \mu \mathrm{m}$, distance PME-ALE $90 \mu \mathrm{m}$, distance AME-AME $40 \mu \mathrm{m}$, diameter AME $180 \mu \mathrm{m}$.

CoLor. Carapace ochre to light brown, with brown median band and narrow light brown margins; brown to light brown stripes radiate from median pit to margins; ocular area ochre to brown, clypeus with light brown band below AME, and dark brown rim (Fig. 76); legs ochre to light brown, with reddish brown to ochre prolateral marks on femora proximally, with brown rings on femora subdistally, patellae + tibiae proximally, and tibiae subdistally, tips of femora and tibiae not whitish (probably an artifact, see variation below); sternum ochre to light brown with narrow brown margins; abdomen beige to light brown with pale yellow and dark dots forming indistinct stripes from dorsal to lateral side of abdomen with large marks dorsally.

BoDy. Ocular area slightly elevated; carapace with distinct median pit and distinctive posterior furrow; clypeus unmodified; sternum wider than long (2.4/1.7); chelicerae as in Figs 83-85, with frontal row of 16-19 modified (cone-shaped) hairs on each side situated on proximally strongly projecting processes; with several cone-shaped, sclerotized processes situated frontally near median line (arrows in Figs 83, 85); without stridulatory ridges (as in Fig. 83); Abdomen globose and high; gonopore with four epiandrous spigots.

PALPS. As in Figs 77-79; coxa unmodified, trochanter with short ventral projection, femur with distinct retrolateral process proximally, ventral membranous area proximally bordered on both sides by heavily sclerotized ridges, and small dorsal projection proximally; femur-patella hinges close together dorsally; patella very short; procursus with proximal dorsal process and weakly developed ventral pocket (Fig. 89), and distal dorsal notch on retrolateral margin; bulb with membranous embolus rising from base of process a; process a elongated, projecting towards retrolaterally with large subdistal hump; process b flattened, band-like, rectangular (Fig. 81); processes c, d and e absent.

LEGS. Without spines; with long curved hairs, especially on tibiae and metatarsi; retrolateral trichobothrium on tibia 1 at $8 \%$; prolateral trichobothrium present on all tibiae; pseudosegmentation not visible.

Male (variation)

Tibia 1 in 3 other males: 11.4, 13.7, 14.2; color pattern on abdomen varies from pale without any marks to light brown with dark and pale dots forming large dorsal marks and fine lateral stripes; leg color varies from light brown to ochre, in fresh specimen from Sudan tips of femora and tibiae whitish; elevated ocular area usually light brown; carapace pattern varies from narrow brown stripes to wide brown marks radiating from median pit to margin (Fig. 76, cf. Koch 1875: fig. 1). 


\section{Female}

In general similar to male; tibia 1 in 2 females: 5.6, 9.8; stridulatory files laterally on chelicerae present; anterior epigynal projections (AEP) sclerotized, elongated (Fig. 86); epigynal plate sclerotized, wide rectangular $(\sim 3 \times$ wider than long) projecting anteriorly between AEP, with median posterior margin gently protruding; some females with two dark dots at base of triangular anterior projection.

\section{Distribution}

We examined specimens from Ethiopia, Eritrea, and Yemen (Fig. 1). The original description by Kulczyński (1901) was apparently based on specimens from Egypt (see Notes below).

\section{Notes}

The original description by Kulczyński (1901) is based on two female specimens, but it does not specify where these females were collected. We assume that Kulczyński examined and illustrated the specimens from Egypt, near Cairo, that L. Koch (1875) had misidentified as Pholcus borbonicus Vinson,
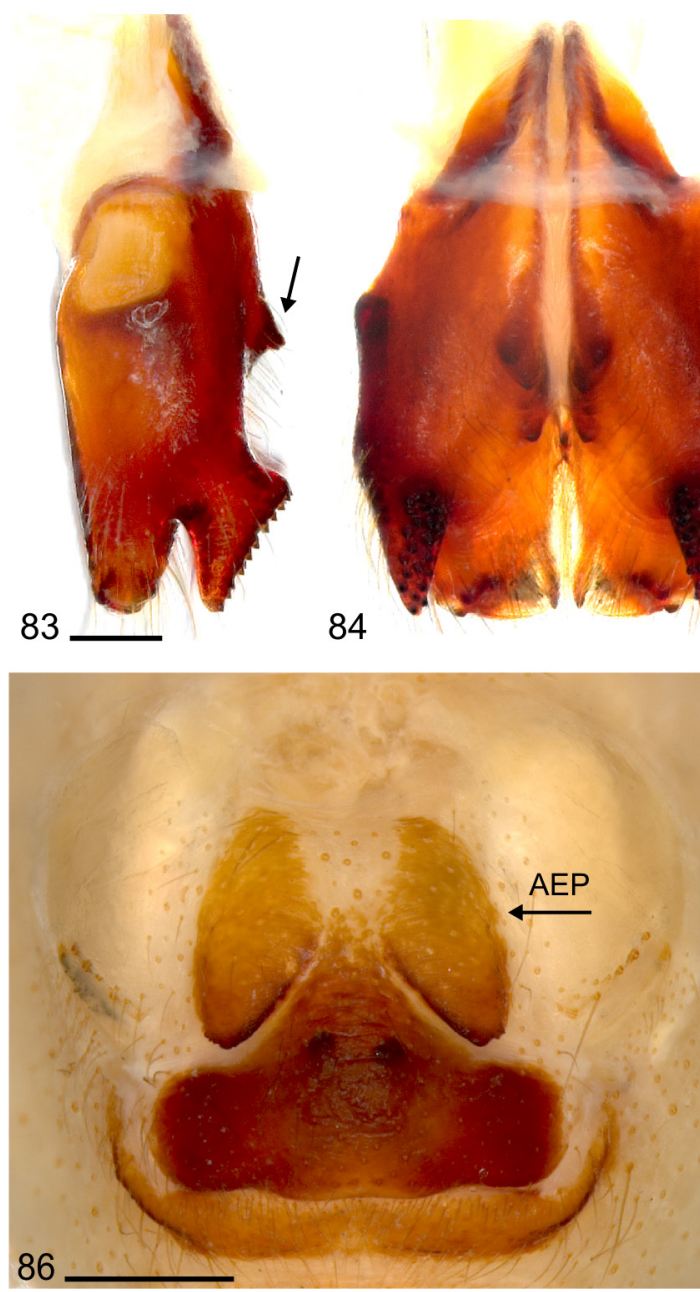

84

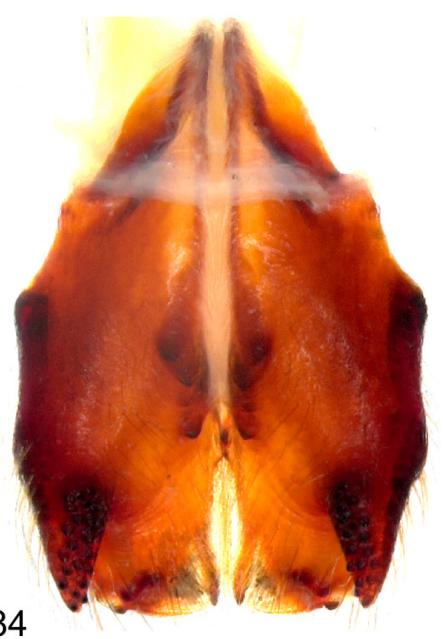

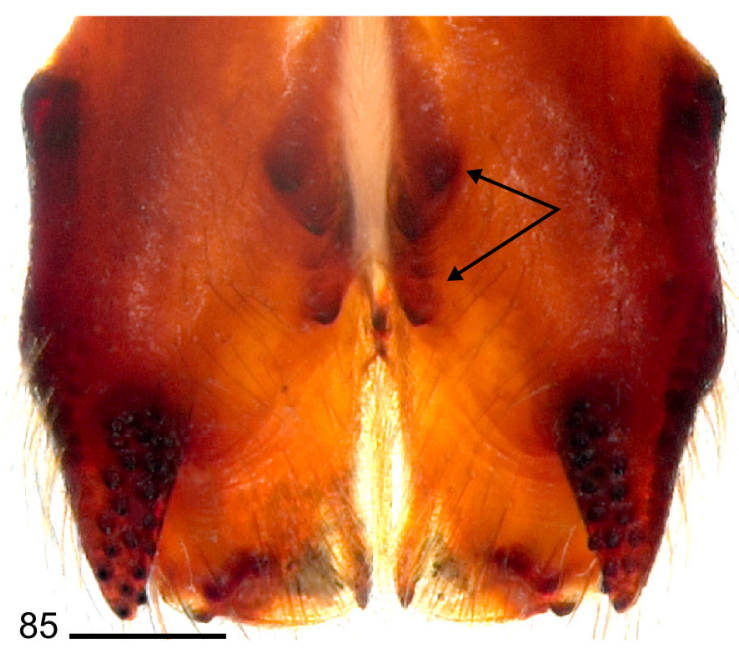
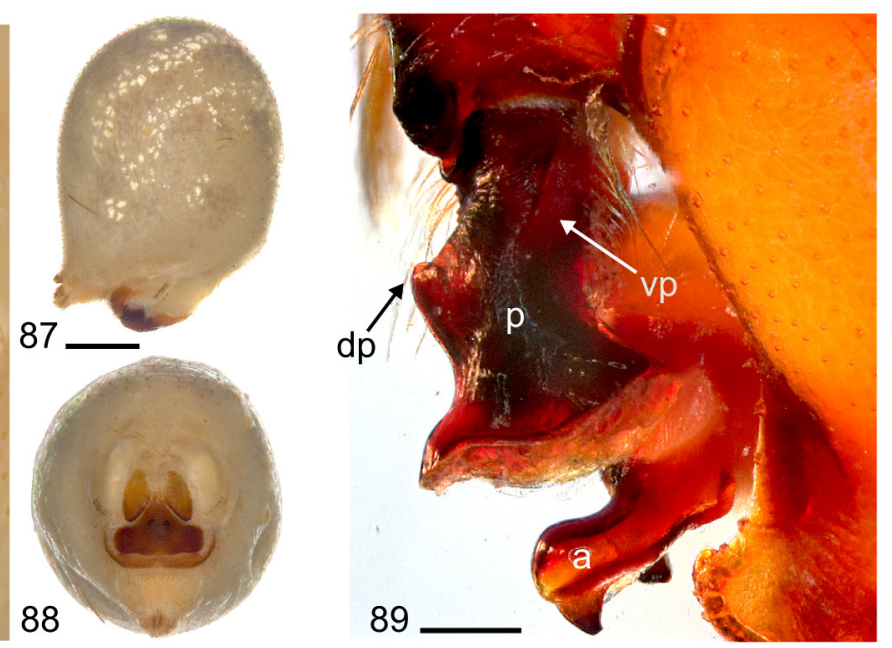

Figs 83-89. Artema kochi Kulczyński, 1901 (MNHN AR 10169 part, Yemen/Eritrea). 83-85. Male chelicerae, lateral and frontal views (arrows: distinctive sclerotized processes frontally near median line). 86. Epigynum and anterior epigynal projections (AEP). 87-88. Female abdomen, lateral and ventral views. 89. Procursus, showing ventral pocket (vp) and dorsal process (dp). Scale lines: 83-85, $89=0.25 \mathrm{~mm} ; 86=0.5 \mathrm{~mm} ; 87-88=1 \mathrm{~mm}$. 
1863 (= A. atlanta). Kulczyński also mentioned specimens from "Massaua" (Eritrea, Massawa) that Thorell (1881) had described in some detail but that he had equally misidentified as Pholcus borbonicus. Since this material from Massawa contains males and females, we conclude that it was not available to Kulczyński. However, we chose to designate a neotype from the material originating from Massawa for three reasons: (1) Kulczyński neither designated type specimens nor specified a type locality; (2) we were not able to locate Koch's specimens from Egypt (they are not in ZMH or ZMB); (3) a good illustration by Kulczyński (1901) of the highly distinctive epigynum of $A$. kochi leaves little doubt that the specimens available to him are, in fact, conspecific with the specimens from Massawa.

Much less obvious is how Simon (1908), after having studied specimens of "A. mauriciana" (= A. atlanta) from many localities, arrived at the conclusion that the drawings of Kulczyński (1901) represented merely slight individual variation and that $A$. koch $i$ was a synonym of "A. mauriciana". This is all the more mysterious because Simon himself had collected A. kochi in Massawa and Aden (in 1889) and his own material (in MNHN, examined) includes not only females, but also the equally distinctive males. We found both species that Simon collected from Massawa and Aden, A. atlanta and A. kochi, deposited in the same vial (Simon collection number 393), so we assume that Simon did not examine all the material in detail but only part of it that happened to be $A$. atlanta.

Artema doriae Thorell, 1881

Figs 1, 90-120, 205, 212

Pholcus doriae Thorell, 1881: 179-180 (in footnote) (, Teheran, Iran). Synonymized with Artema atlanta by Pickard-Cambridge 1902: 366; revalidated by Brignoli 1981: 92.

Artema doriai (unjustified emendation; see Etymology below) - Simon 1893: 465. - Tabrizi et al. 2014: 35, figs 1M-N, 3L-M. — Malek Hosseini et al. 2015: 92.

\section{Misidentifications}

"Artema transcaspica" - Denis 1958: 112 (Afghanistan). - Roewer 1955: 752 (Iran). — Gharari \& Marusik 2009: 4 (Iran). See Note below.

\section{Etymology}

Even though the species was named for a man (Marchese Giacomo Doria, 1840-1913), the ICZN (1999: article 31.1) clearly states that the correct patronym has to be doriae, not doriai. The latter is thus an unjustified emendation.

\section{Diagnosis}

Artema doriae is easily distinguished from other congeners (except A. transcaspica and Artema sp. c.) by the arrangement of modified hairs situated frontally on cheliceral processes (Fig. 98), by the triangular bulbal process c, usually curved and pointing towards prolateral (Fig. 95), and by the distinct ventral process d (Fig. 94). Males are possibly distinguishable from A. transcaspica and Artema sp. c by the cheliceral proximal incline usually with small ridge or process above modified hairs in lateral view (arrows in Figs 100-102) (A. transcaspica usually with smooth incline proximally of modified hairs, see arrows in Figs 131-133; Artema sp. c with robust ridge or process above modified hairs, see arrows in Figs 190-191). Females differ more easily from other congeners (except A. transcaspica and Artema sp. c) by their quadrilateral epigynal shape. Females appear distinguishable from A. transcaspica by their more trapezoidal epigynal plate rather than rectangular to square-shaped, by median sclerite not reaching posterior margin, and by more distinct and inflated pale median area posteriorly (compare Figs 103-114 with Figs 134-145); Artema sp. c differs by wider epigynal plate, and by more inflated and prominent pale median area of epigynal plate (Figs 195-200). 
AHARON S. et al., Revision of the spider genus Artema (Araneae, Pholcidae)

\section{Material examined}

\section{Syntypes}

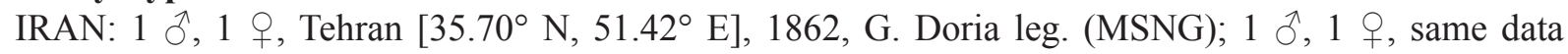
(MNHN AR 10180) (E. Simon collection number 397).

\section{Other material}

ISRAEL: 1 क, Upper Galilee, Ramot Naftali $\left(33.08^{\circ} \mathrm{N}, 35.54^{\circ} \mathrm{E}\right), 15$ May 2012, S. Zonstein leg.

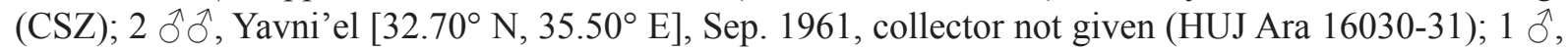
Poriyya slope $\left[32.73^{\circ} \mathrm{N}, 35.54^{\circ} \mathrm{E}\right]$, Sep. 1970, Pener et al. leg. (HUJ Ara 16032); 1 \&, Nachal Chagal, $\mathrm{N}$ of Gesher $\left(32.634^{\circ} \mathrm{N}, 35.534^{\circ} \mathrm{E}\right), 3$ Dec. 2010, L. Friedman and C. Drees leg. (CSZ); 1 \%, Memorial Ha-Biq'a, NE Peza'el (32.052 ${ }^{\circ}$ N, 35.458 ${ }^{\circ}$ E), in cave, 10 Mar. 2014, S. Aharon and E. Gavish-Regev

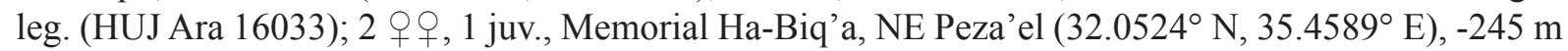
b.s.l., at base of stonewall, 15 Sep. 2013, B.A. Huber, S. Aharon and E. Gavish-Regev (ZFMK Ar 15243-44); 1 ㅇ, 2 juvs, in pure ethanol, same data (ZFMK Isr 40); 1 을 Jericho [31.89 ${ }^{\circ} \mathrm{N}, 35.42^{\circ} \mathrm{E}$ ], 25 Feb. 1968, G. Tsabar leg. (HUJ Ara 16034); 1 \%, same locality, 12 Dec. 1967, P. Amitai leg. (HUJ Ara 16035); 1 juv., same locality, 20 Oct. 1969, P. Amitai (HUJ Ara 16036); 6 우, Modi' in $\left(31.893^{\circ} \mathrm{N}\right.$, $34.971^{\circ}$ E), pitfall trap in shrub habitat, Apr. 2012, I. Berenstein et al. leg. (SMNH); 1 ô, Hazeva $\left[30.76^{\circ} \mathrm{N}, 35.27^{\circ} \mathrm{E}\right], 17$ Jun. 2010, L. Friedman and C. Drees (CSZ); 1 q, near Hazeva $\left[30.76^{\circ} \mathrm{N}\right.$, 35.27 E], 11 Aug. 2014, Akiva Topper leg. (HUJ Ara 16037).
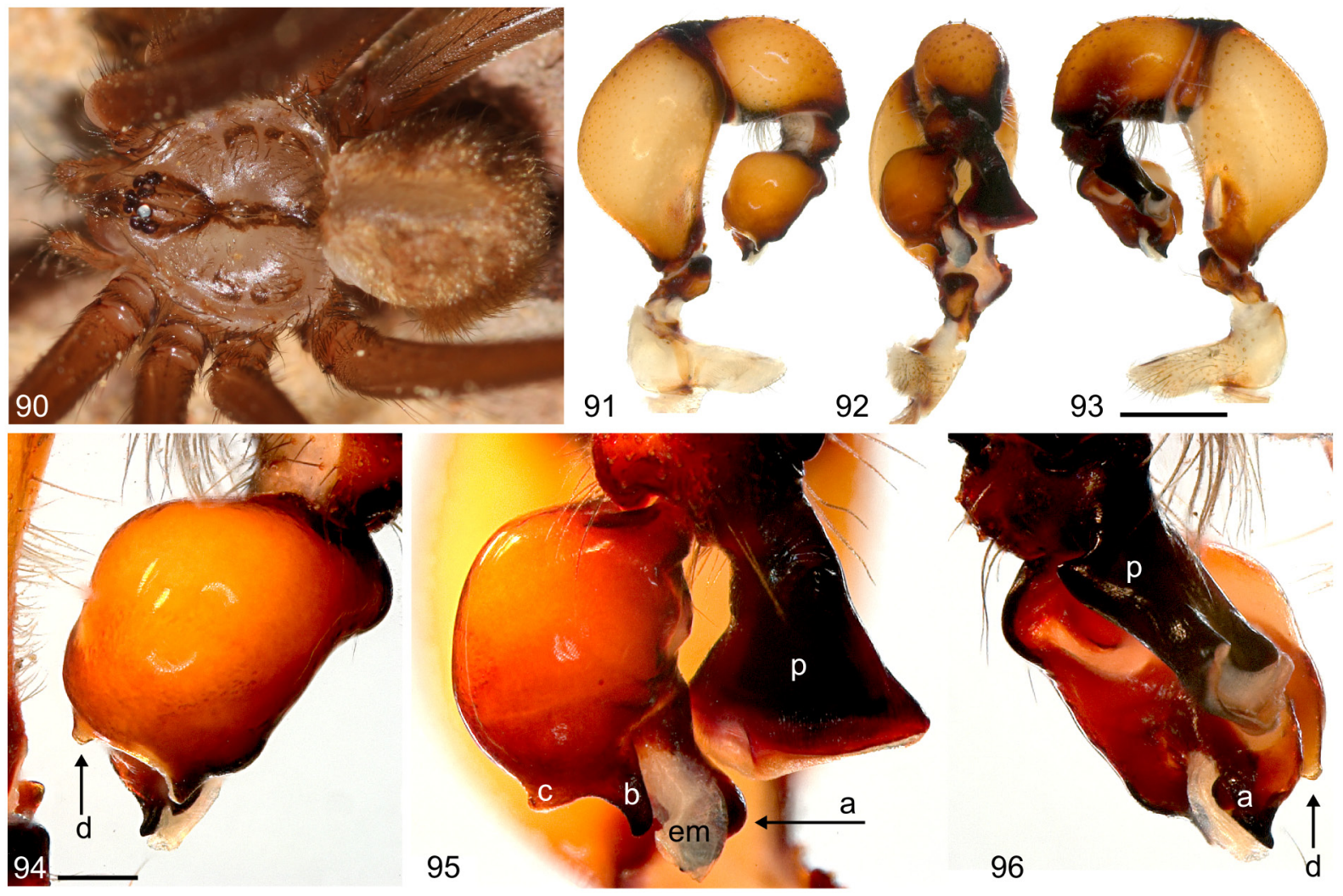

Figs 90-96. Artema doriae Thorell, 1881. 90. Female, habitus (HUJ Ara 16033, Israel, Memorial HaBiq'a, NE Peza'el). 91-93. Male left pedipalp (ZFMK Ar 15233, Iran, Tehran): prolateral, dorsal, and retrolateral views. 94-96. Male left bulb and procursus (same specimen): prolateral, dorsal, and retrolateral views. Scale lines: $91-93=1 \mathrm{~mm} ; 94-96=0.25 \mathrm{~mm}$. 


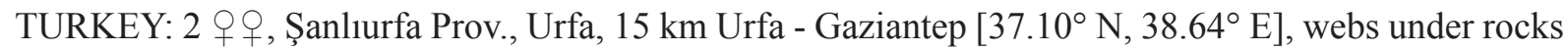
on dry rocky hills, 12 Sep. 1956, collector not given (XUM); 1 ㅇ, 1 juv., Diyarbakır Prov., Çermik [38.14 N, 39.45 E], 700 m a.s.1., 27 Jul. 2004, T. Danisman leg. (ZFMK Ar 15931).

IRAN: $1 \hat{\partial}$, Tehran, 15 Oct. 1938, collector not given (NHMW 354); 1 $\widehat{O}, 1$ †, Tehran Prov., Tochal $\left(35.827^{\circ} \mathrm{N}, 51.406^{\circ} \mathrm{E}\right), 6$ Jun. 2013, A. Zamani leg. (ZFMK Ar 15233-34); 1 ô, Alborz Prov., Karaj $\left(35.84^{\circ} \mathrm{N}, 50.95^{\circ} \mathrm{E}\right)$, date not given, Ressl leg. (ZFMK Ar 15930); 2 $\oint^{\Uparrow}, 2$ 우, 1 juv., Lorestan Prov.,

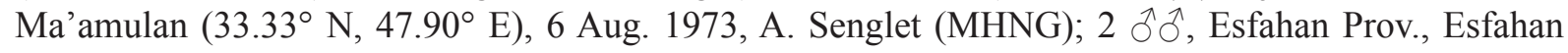
$\left(32.56^{\circ} \mathrm{N}, 51.51^{\circ}\right.$ E), 23 Aug. 1973, A. Senglet leg. (MHNG); 1 , Esfahan, 18-20 Aug. 1934, H. Field and

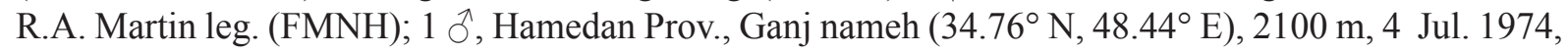
A. Senglet leg (MHNG); 1 ○, Fars Prov., Allabad (30.01 ${ }^{\circ}$ N, 53.00 E), 9 Jun. 1974, A. Senglet leg. (MHNG); 1 đ , 1 \& , Fars Prov., Bishapour $\left(29.78^{\circ}\right.$ N, $51.58^{\circ}$ E), 28 May 1974, A. Senglet leg. (MHNG); 1 o, Kermanshah Prov., SE of Berendjan ( $34.55^{\circ}$ N, 47.03 E), 12 Sep. 1975, A. Senglet leg. (MHNG); 1 , , Yazd Prov., $10 \mathrm{~km} \mathrm{NE}$ of Bafq $\left(31.70^{\circ} \mathrm{N}, 55.53^{\circ} \mathrm{E}\right), 1260 \mathrm{~m}, 10 \mathrm{Apr} .2004$, V. Vignoli and P. Crucitti

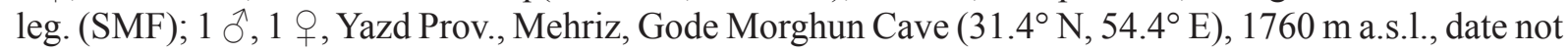

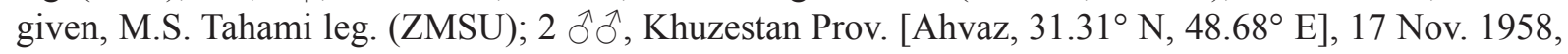

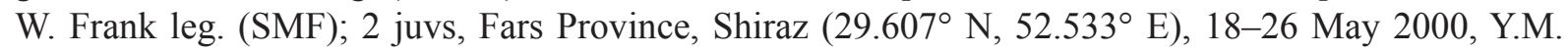
Marusik leg. (ZFMK Ar 15235); 1 ภ, 1 q, 2 juvs, Fars Province, $50 \mathrm{~km}$ NNE of Shiraz $\left(29.75^{\circ} \mathrm{N}\right.$, $52.75^{\circ}$ E), 18-28 May 2000, Y.M. Marusik leg. (ZFMK Ar 15236); 1 §, Fars Province, "Hosseinie
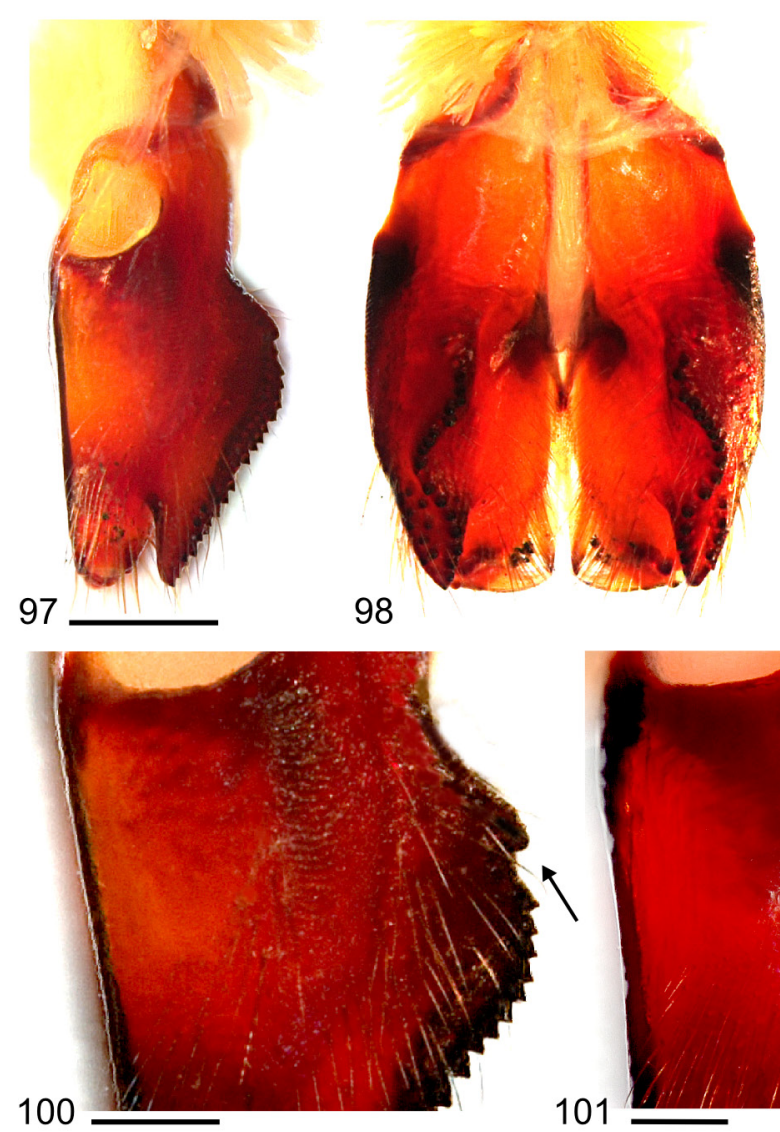
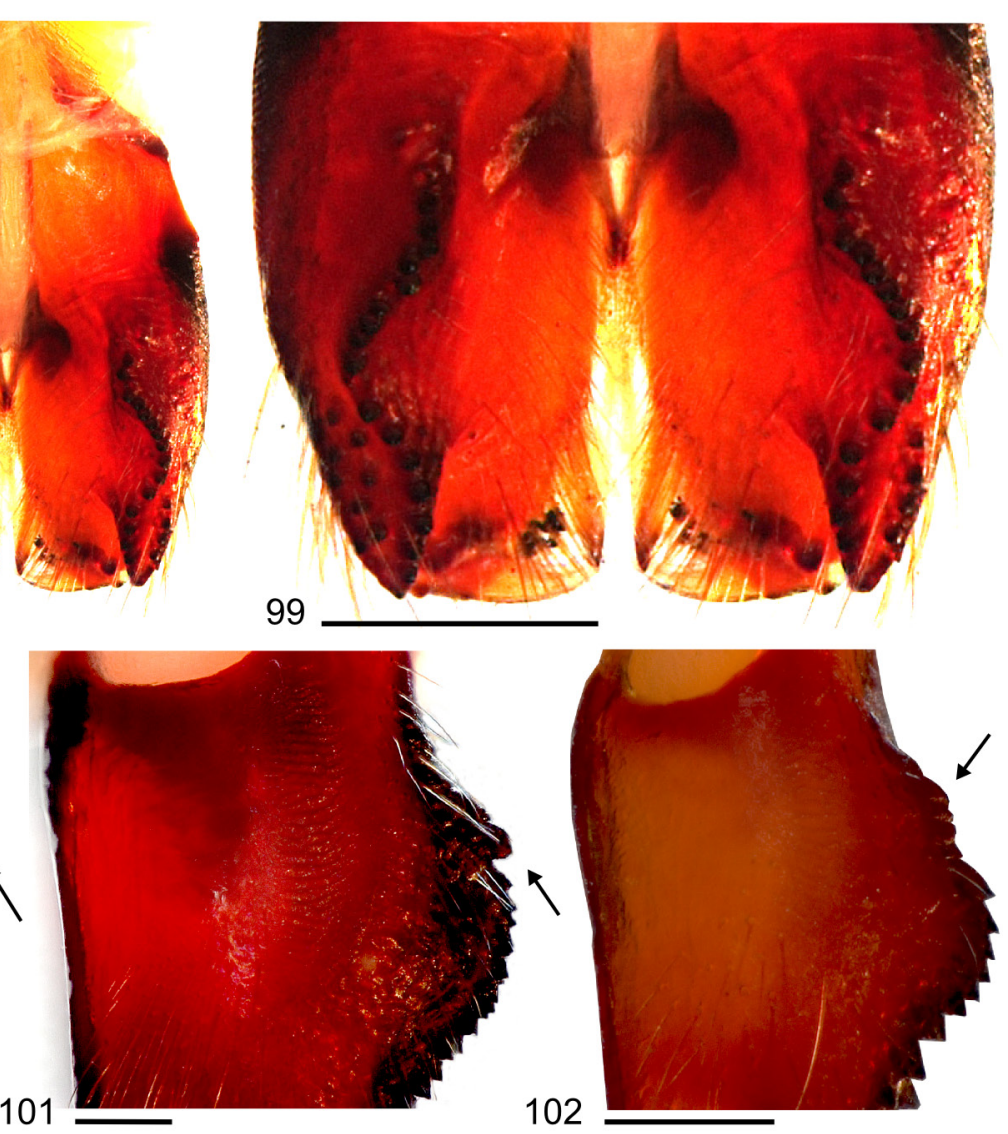

Figs 97-102. Artema doriae Thorell, 1881, male chelicerae in lateral and frontal views. 97-99. Iran, Tehran (MNHN Ar 10180). 100-101. Iran, Tehran (ZFMK Ar 15233 and SMF). 102. Israel, Yavni'el $($ HUJ Ara 16030). Arrows $=$ projections proximally on frontal process. Scale lines: $97-99=0.5 \mathrm{~mm}$; $100-102=0.2 \mathrm{~mm}$. 
House" [29.63 $\left.{ }^{\circ} \mathrm{N}, 52.51^{\circ} \mathrm{E}\right], 27$ May 1981, collector not given (ZFMK Ar 15237); 1 q, University of Shiraz [29.63 N, 52.51 ${ }^{\circ}$ E], 29 May 2000, F. Hosseinie leg. (ZFMK Ar 15238).

UNITED ARAB EMIRATES: 2 우, Sharjah Desert Park $\left(25.28^{\circ} \mathrm{N}, 55.69^{\circ} \mathrm{E}\right)$, hand-collected, 24 Feb. 2005, C. Griffioen leg. (ZFMK Ar 15239); 2 우, same locality, in pitfall traps, 6-28 Dec. 2006, A. van Harten leg. (ZFMK Ar 15240); 1 +, same locality, hand-collected, 6 Oct. 2004, C. Griffioen leg. (ZFMK Ar 15241); 1 , Um al-Quwain $\left(25.51^{\circ} \mathrm{N}, 55.53^{\circ} \mathrm{E}\right)$, in pitfall traps, $1-30$ Nov. 2008, A. van Harten leg. (ZFMK Ar 15242); 2 우, Dubai, Deira, inside Al Quisais Mosque (25.277 N, 55.373 ${ }^{\circ} \mathrm{E}$ ), 7 May 2014, N. Iqbal leg. (NHMUK); $1 \hat{\jmath}$ (palps missing), 1 juv., Dubai, Falcon City, in building $\left(25.087^{\circ} \mathrm{N}, 55.360^{\circ} \mathrm{E}\right), 22$ May 2014, Morshid leg. (NHMUK).

AFGHANISTAN: $1 \overbrace{}^{\Uparrow}$, Herat $\left(34.33^{\circ} \mathrm{N}, 62.21^{\circ} \mathrm{E}\right), 15$ Aug. 1975, A. Senglet leg. (MHNG).

JAPAN: 1 q, Okayama Pref., Kasaoka Port [34.5 N, 133.5 E], Kasaoka-shi, 23 Dec. 1995, K. Nojima leg. (ZFMK Ar 5203).
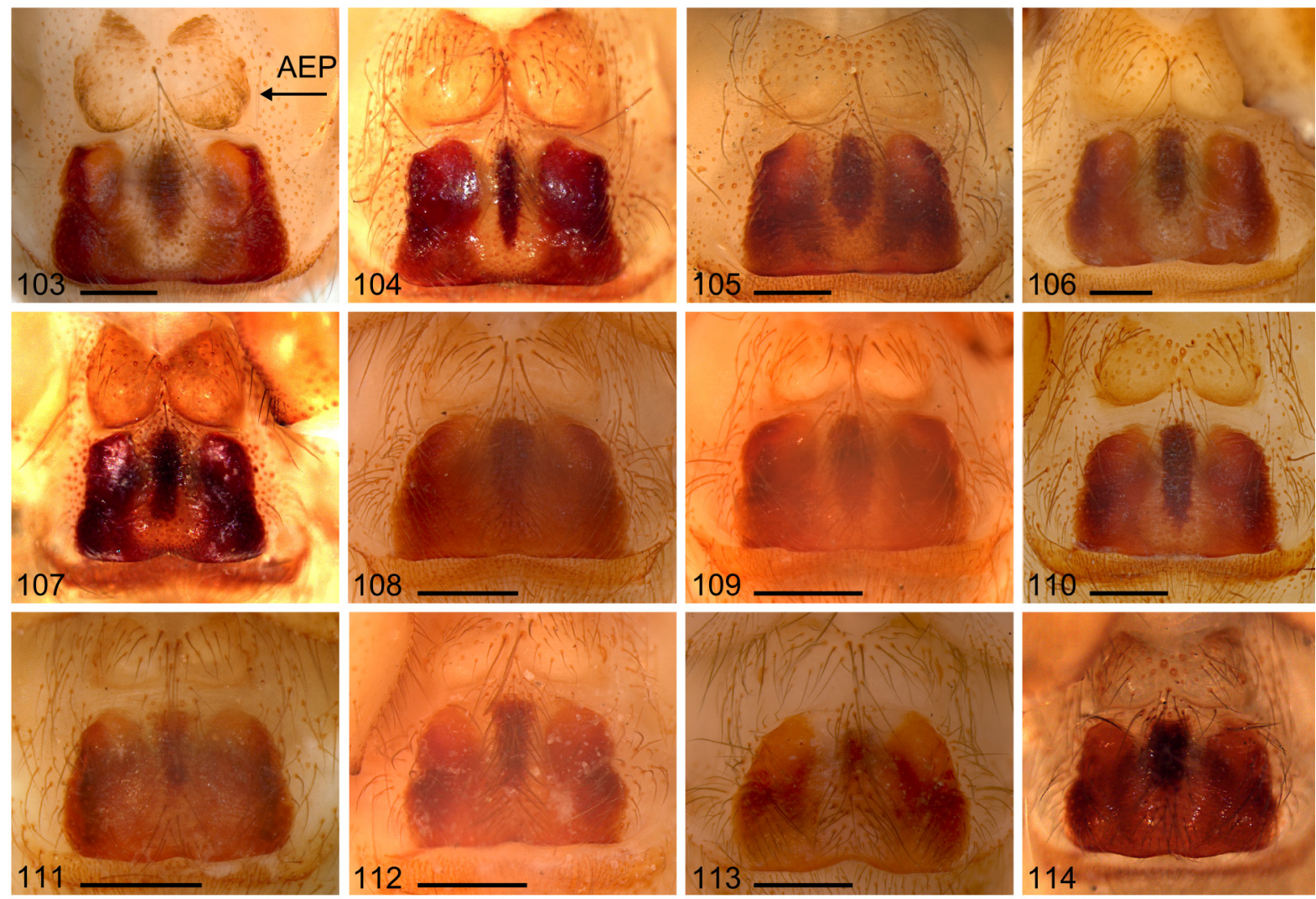

Figs 103-114. Artema doriae Thorell, 1881, intraspecific variation of epigynum. 103. Iran, Tochal (ZFMK Ar 15233). 104. Iran, Esfahan (FMNH). 105. Iran, Lorestan, Ma'amulan (MHNG). 106. Iran, Tehran (MNHN AR 10180). 107. Iran, 10 km NE of Bafq (SMF). 108-109. Turkey, Urfa-Gaziantep (XUM). 110. Turkey, Diyarbakır Prov., Çermik (ZFMK Ar 15931). 111. Israel, Upper Galilee, Ramot Naftali (CSZ). 112. Israel, Jericho (HUJ Ara 16035). 113. Israel, Memorial Ha-Biq'a, NE Peza'el (HUJ Ara 16033). 114. Israel, Modiin (SMNH). Scale lines: 103, 105-113 = $0.5 \mathrm{~mm}$. 


\section{Description}

Male (MNHN AR 10180)

MeAsurements. Total body length 8.5, carapace width 4.1. Leg 1: $60.8(16.0+1.9+18.2+21.2+3.5)$, tibia 2: 14.2, tibia 3: 10.0, tibia 4: 13.8; tibia $1 \mathrm{~L} / \mathrm{d}$ : 36. Distance PME-PME $220 \mu \mathrm{m}$, diameter PME $200 \mu \mathrm{m}$, distance PME-ALE $140 \mu \mathrm{m}$, distance AME-AME $50 \mu \mathrm{m}$, diameter AME $190 \mu \mathrm{m}$.

Color. Carapace ochre with light brown median band; ocular area light brown, clypeus with subtle brown rim and light brown band below AME enlarged at base of clypeus to triangular shape (as in Fig. 90); legs ochre yellow to ochre without dark rings on femora subdistally but with light brown rings on patellae + tibiae proximally, and tibiae subdistally, tips of femora and tibiae not whitish; sternum ochre with narrow brown margins; abdomen beige with indistinct pale stripes from dorsal to posterior of abdomen with several marks dorsally.

Body. Ocular area slightly elevated; carapace with distinct posterior furrow and distinct median pit; clypeus unmodified; sternum wider than long (3.0/2.2); chelicerae, with frontal row of $\sim 20-25$ modified (cone-shaped) hairs on each side, situated on elevated process (see Figs 97-99); cheliceral proximal incline in lateral view with distinct small process above modified hairs (see Fig. 97); with stridulatory ridges laterally (as in Fig. 118); abdomen globose and high; gonopore with four epiandrous spigots.
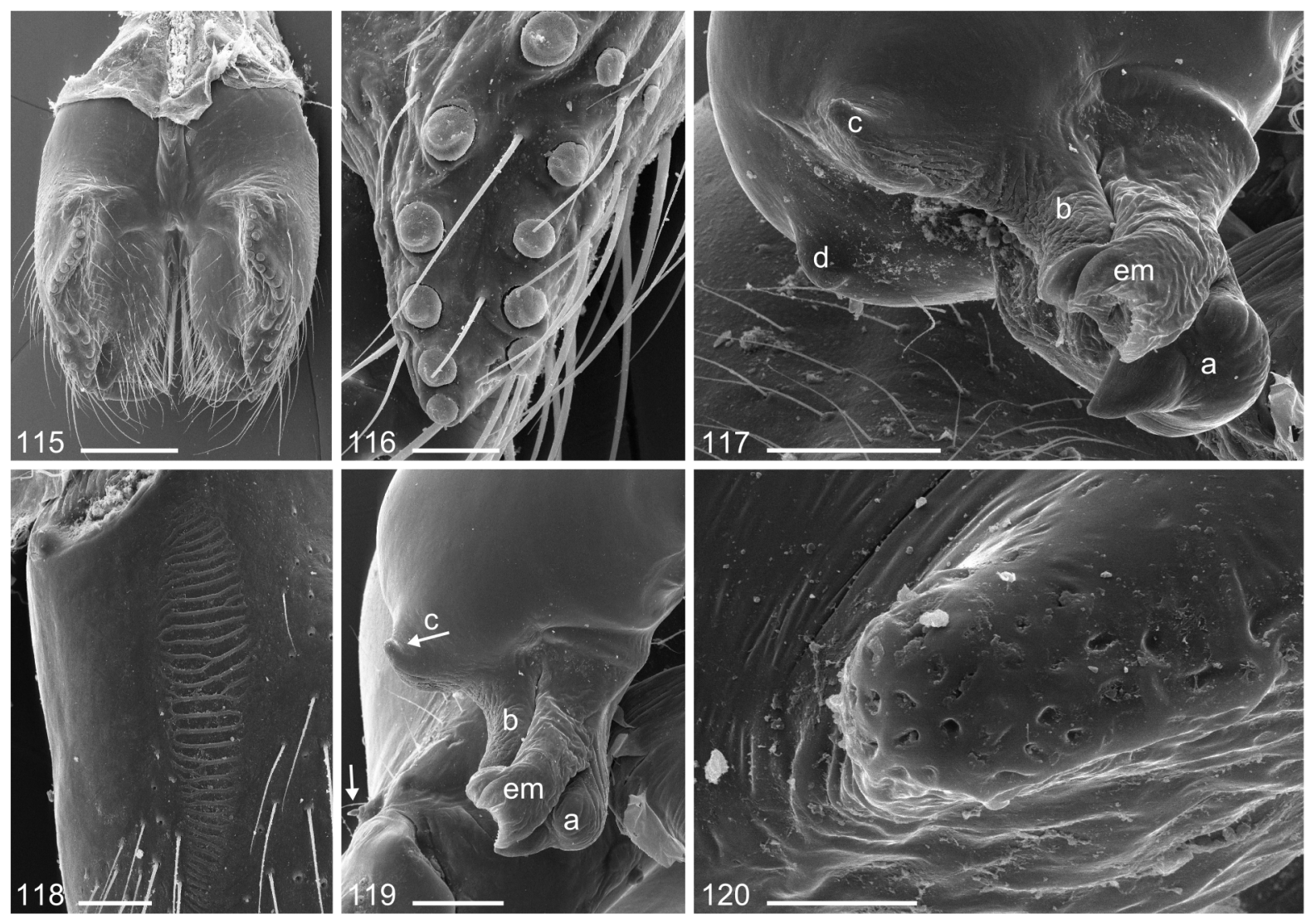

Figs 115-120. Artema doriae Thorell, 1881, MHNG, Ma'amulan (Iran). 115-116. Male chelicerae with frontal rows of modified (cone-shaped) hairs. 117. Male left bulbal processes. 118. Male stridulatory ridges. 119. Male left bulbal processes; arrow points at modified hair on palpal femur used for stridulation. 120. Apophysis $\mathrm{c}$ with putative pores. Scale lines: $115=0.4 \mathrm{~mm} ; 116=0.06 \mathrm{~mm} ; 117,119=0.2 \mathrm{~mm}$; $118=0.1 \mathrm{~mm} ; 120=0.02 \mathrm{~mm}$. 
PALPS. Coxa unmodified, trochanter with short ventral projection, femur with distinct retrolateral process proximally, ventral membranous area proximally bordered on both sides by heavily sclerotized ridges, and small dorsal projection proximally; femur-patella hinges close together dorsally; patella very short; procursus with proximal dorsal process and weakly developed ventral pocket, and distal dorsal notch on prolateral sclerotized margin (as in Fig. 95); bulb with membranous embolus rising from base of processes a and b; process a with subdistal hump ; process b narrow, elongated, and pointed; process $\mathrm{c}$ small, triangular (as in Fig. 95); process d is a distinct small ventral projection distally (as in Figs 94, 96).

LEGS. Without spines; with long curved hairs, especially on tibiae and metatarsi; retrolateral trichobothrium on tibia 1 at $8 \%$; prolateral trichobothrium present on all tibiae; pseudosegmentation not visible.

Male (variation)

Tibia 1 in 19 other males: 8.0-22.2 (mean 14.5); color pattern on abdomen varies from pale without any marks to beige with lateral stripes and large marks dorsally; leg color varies from light brown to ochre; ocular area usually light brown; carapace pattern varies from sub-marginal brown marks to pale carapace with median band only; clypeus sometimes without dark band; process c varies in length, sometimes curved and pointing towards prolateral; lateral stridulatory ridges usually present and easy to notice (Fig. 118), sometimes invisible; cheliceral proximal incline (in lateral view) usually with ridge or small process above modified hairs, sometimes absent or indistinct (Figs 97, 100-102).

\section{Female}

In general similar to male; tibia 1 in 20 females: 5.3-14.3 (mean 8.3); stridulatory files laterally on chelicerae more distinct than in males; epigynal plate trapezoidal, consisting of two sclerotized lateral areas that are wider posteriorly, gently swollen posteriorly, and depressed medially anteriorly, pale median area inflated posteriorly with dark median sclerite $1 / 3-2 / 3$ the length of epigynal plate and not fused at posterior epigynal margin with lateral sclerotized plates, epigynal posterior margin usually straight, sometimes with small median indentation (i.e., Figs 111, 113-114); anterior epigynal projections oval, not prominent in lateral view. Intraspecific variation of epigynum as shown in Figs 103-114.

\section{Distribution}

This species is widespread, ranging from Israel and eastern Turkey in the west, to Afghanistan in the east (Fig. 1). The single specimen from Japan is most probably a human introduction.

\section{Note}

We have not seen the material identified by Denis (1958), Roewer (1955), and Ghahari \& Marusik (2009) as $A$. transcaspica (from Pirzada, Afghanistan, and various localities in Iran, respectively). We assume that these authors were all dealing with the very similar $A$. doriae, judging from its known distribution (we examined one male of $A$. doriae that was collected from Herat, Afghanistan, and the Iranian localities in the papers above also suggest $A$. doriae rather than $A$. transcaspica).

Artema transcaspica Spassky, 1934

Figs 1, 121-154, 206, 213

Artema transcaspica Spassky, 1934: 369-372, figs 8-10 (ð̊ q, Turkmenistan, Tajikistan).

\section{Misidentifications}

Artema transcaspica - Denis 1958: 112 (Afghanistan). - Roewer 1955: 752 (Iran). Ghahari \& Marusik 2009: 4 (Iran). See redescription of $A$. doriae above. 


\section{Diagnosis}

Males are easily distinguished from most other known congeners (except A. doriae and Artema sp. c) by their bulbal processes (Figs 125-127): process c triangular, curved and pointing towards prolateral, and distinct ventral process d. Males are possibly distinguishable from A. doriae and from Artema sp. c by their cheliceral proximal incline without ridge or process above modified hairs in lateral view (Figs 128, 131-133) which is present in A. doriae (Figs 100-102) and in Artema sp. c (Figs 186-191). Females differ from other congeners by their rectangular to square-shaped epigynal plate (i.e., lateral margins parallel; Figs 134-145, 150) (rather slightly trapezoidal in A. doriae, rectangular and wider in Artema sp. c); by dark median sclerite fused at posterior epigynal margin with lateral sclerotized plates (not fused in A. doriae and Artema sp. c) and by less distinct pale median area posteriorly (in A. doriae the pale median area is usually distinct posteriorly, very prominent in Artema sp. c).

\section{Material examined}

\section{Syntypes}

The ZIN collection has three vials, two of which (with a total of $10 \hat{\partial} \sigma^{\lambda}, 18$ 우, $\sim 15$ juvs) contain both syntypes (as suggested by the label data) and non-types; the third (with $2 \lambda \hat{\alpha}, 1$ juv.) may contain syntypes only, but the label does not specify any collection data. A further vial in MNHN may contain syntypes only $(1 \hat{\jmath}, 2$ 우), but the collection data are also unclear. For these reasons, we list here all the material from these four vials, sorted by country. Specimen numbers are taken from the original description, but since
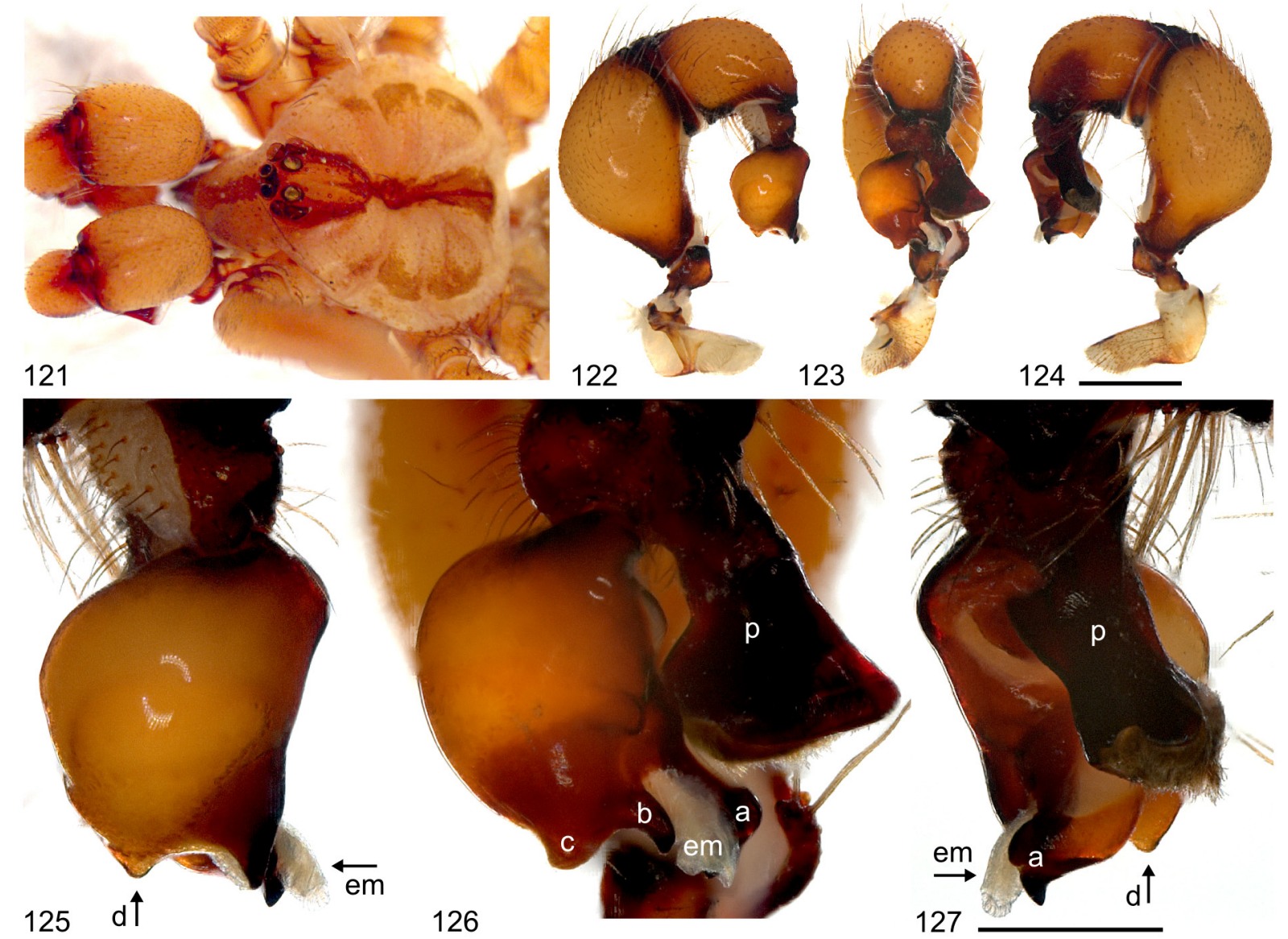

Figs 121-127. Artema transcaspica Spassky, 1934. 121. Õ, habitus (ZIN type vials). 122-124. Male left pedipalp (ZMMU, Uzbekistan, near Zarafshon): prolateral, dorsal, and retrolateral views. 125127. Male left bulb and procursus: prolateral, dorsal, and retrolateral views. Scale lines: $122-124=$ $1 \mathrm{~mm} ; 125-127=0.5 \mathrm{~mm}$. 
specimens from different localities and collection dates were combined, individual specimens can no longer be attributed to different localities. This is why specimen numbers are unspecified in two cases below.

TAJIKISTAN: syntype $q$, "Stalinabad" [= Dushanbe, $38.53^{\circ} \mathrm{N}, 68.78^{\circ} \mathrm{E}$ ], summer 1933, A. Alparov leg. (ZIN).

TURKMENISTAN: unspecified number of syntypes and non-types, "Ashkhabad" [=Ashgabat, $37.93^{\circ} \mathrm{N}$, $58.36^{\circ}$ E], spring 1933, E. Mel'nikova leg. (syntypes) and 16 Apr. 1934, M.K. Laptev leg. (non-types) (ZIN); unspecified number of non-types, same locality, in room, 5 Sep. 1936, collector not given (ZIN); 1 Oे, syntype, "Krasnovodsk" [= Türkmenbasy, 40.01 N, 52.96 E], summer 1900, Ahnger leg. (ZIN); 1 juv., syntype, Repetek, "Transcaspian Province" [38.56 $\left.{ }^{\circ} \mathrm{N}, 63.18^{\circ} \mathrm{E}\right], 1907$, Dolgopolov leg. (ZIN);

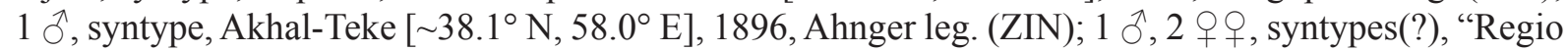
Transcaspica", date and collector not given (these are possibly part of the specimens from Ashkhabad collected in 1933 by Mel'nikova) (MNHN Ar 10178).

UZBEKISTAN: 1 ㅇ (non-type), “Andizhan" [= Andijan, 40.80 N, 72.30 E], in house, winter 1938, Karpovich leg. (ZIN).

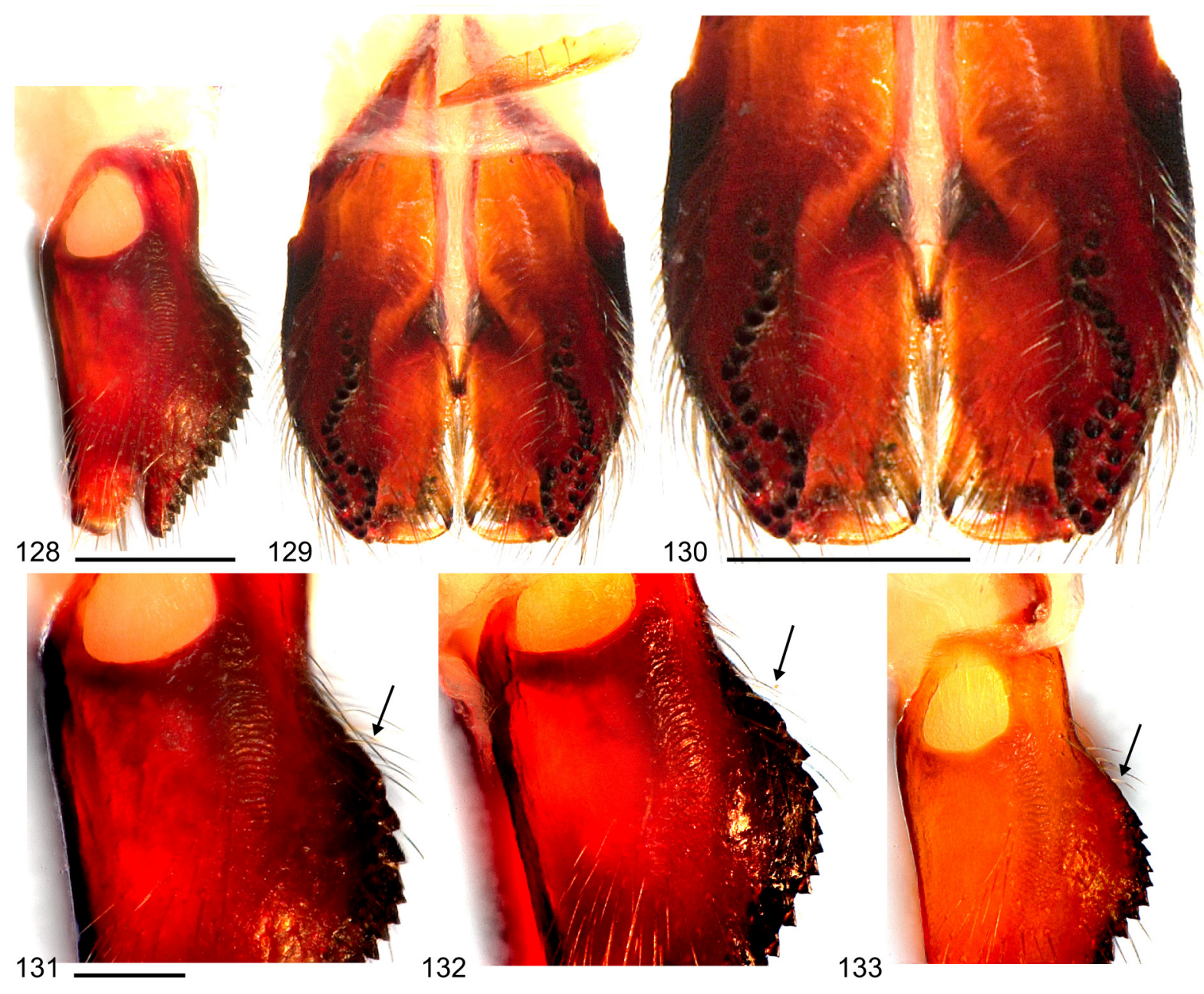

Figs 128-133. Artema transcaspica Spassky, 1934, male chelicerae in lateral and frontal views. 128-

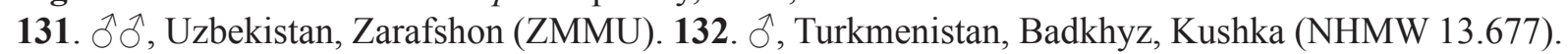

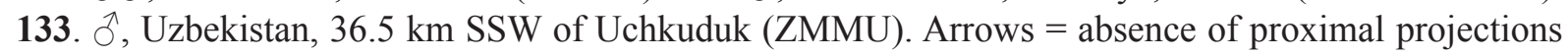
on frontal processes. Scale lines: $128-130=0.5 \mathrm{~mm} ; 131-133=0.2 \mathrm{~mm}$. 


\section{Other material}

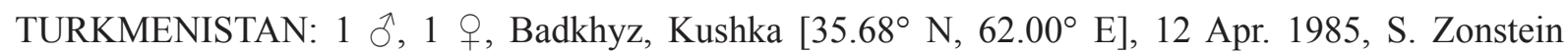
leg. (NHMW 13.677); 1 q, Kopetdag, Parkhai $\left[\sim 38.25^{\circ} \mathrm{N}, 57.8^{\circ} \mathrm{E}\right]$, in house, 19 Dec. 1992, V.I. Perepechaenko leg. (ZFMK Ar 15245).

UZBEKISTAN: $1 \hat{\jmath}$, Navoi Area, Uchkuduk District, Kyzylkum Desert, ca 36.5 km SSW of Uchkuduk, ca $6 \mathrm{~km}$ SWS of Tasbulak Well, $120 \mathrm{~m}$ a.s.1., sands $\left(41.85^{\circ} \mathrm{N}, 63.30^{\circ} \mathrm{E}\right), 2$ Jun. 2003, A.V. Gromov

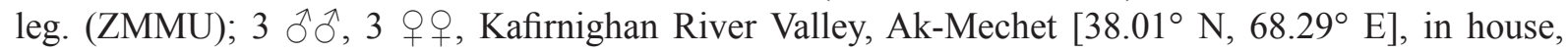

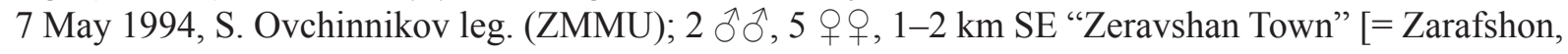
$\left.41.57^{\circ} \mathrm{N}, 64.24^{\circ} \mathrm{E}\right], 20$ Apr.-19 Jul. 1998, A.V. Gromov leg. (ZMMU); 1 o, Bukhara Area [39.51 ${ }^{\circ} \mathrm{N}$, $64.84^{\circ} \mathrm{E}$ ], $33 \mathrm{~km}$ SE of Bukhara, 19-20 May 1994, A.A. Zyuzin leg. (ZMMU).

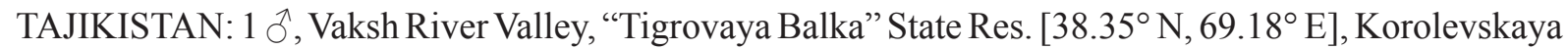
Dacha, 3 Aug. 2006, S.V. Ovchinnikov leg. (ZMMU); 1 q, in pure ethanol, Khatton Area, Shaartuz Distr., Khushody $\left(37.152^{\circ} \mathrm{N}, 68.070^{\circ} \mathrm{E}\right), 378 \mathrm{~m}$ a.s.l., edge of sandy desert, shrub litter, 20 Apr. 2015,

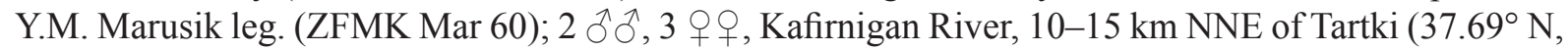
$68.15^{\circ} \mathrm{E}$ ), inside solitary abandoned farmer house near riverbank, 12 Jun. 1989, S. Zonstein leg. (SMNH).

Material assigned tentatively (see Notes below)

UNITED ARAB EMIRATES: 1 9 , $\mathrm{N}$ of Ajman $\left(25.43^{\circ} \mathrm{N}, 55.48^{\circ} \mathrm{E}\right)$, in water traps, 21 Sep. -25 Oct. 2007, A. van Harten leg. (ZFMK Ar 15246).
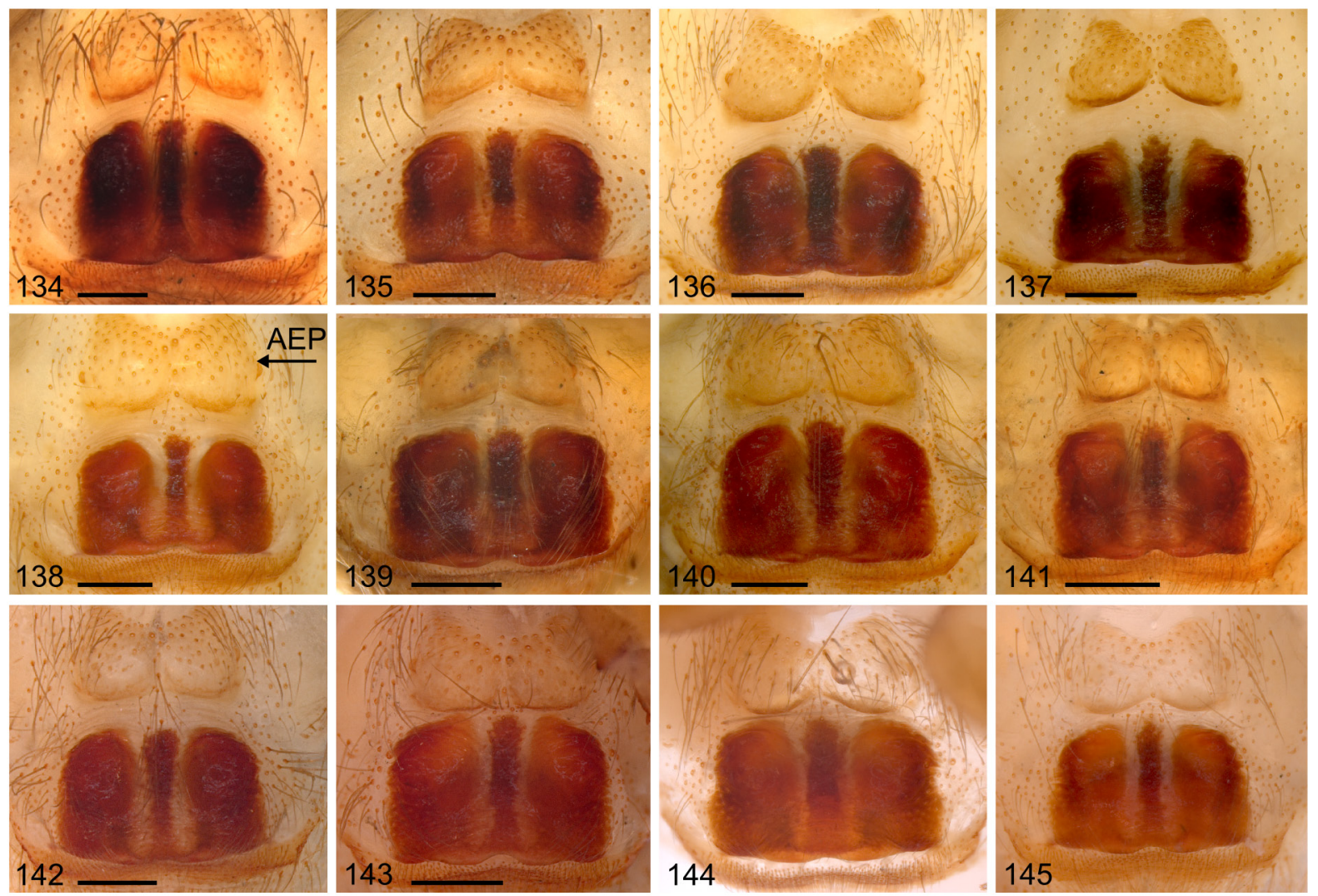

Figs 134-145. Artema transcaspica Spassky, 1934, intraspecific variation of epigynum. 134. Uzbekistan, SE Bukhara (ZMMU). 135. Uzbekistan, Ak-Mechat (ZMMU). 136-137. Uzbekistan, SE Zarafshon (ZMMU). 138. Turkmenistan, Badkhyz, Kushka (NHMW 13.677). 139-145. Unspecified data: Tajikistan\Turkmenistan\Uzbekistan (ZIN type vials). Scale lines: $0.5 \mathrm{~mm}$. 


\section{Description}

Male (unspecified origin; ZIN type vial)

MEAsurements. Total body length 5.7, carapace width 3.1. Leg 1: $39.1(10.1+1.3+11.5+14.0+2.2)$, tibia 2: 9.0, tibia 3: 7.0, tibia 4: 9.3; tibia 1 L/d: 38. Distance PME-PME $150 \mu \mathrm{m}$, diameter PME $190 \mu \mathrm{m}$, distance PME-ALE $90 \mu \mathrm{m}$, distance AME-AME $60 \mu \mathrm{m}$, diameter AME $180 \mu \mathrm{m}$.

CoLor. Carapace light ochre with large brown radial marks, with brown median band that splits at posterior margin of ocular area; ocular area ochre to brown, clypeus with dark brown rim and light brown band below AME enlarged at base of clypeus to triangular shape (as in Fig. 121); legs ochre yellow without dark rings on femora, patellae, and tibiae; sternum ochre to light brown with narrow brown margins; abdomen without distinct pattern.

BoDy. Ocular area slightly elevated; carapace with distinct posterior furrow and distinct median pit close to posterior margin of ocular area; clypeus unmodified; sternum wider than long (2.1/1.7); chelicerae as in Figs 128-130, with frontal row of $\sim 25$ modified (cone-shaped) hairs on each side, situated on elevated process (as in Figs. 146-148); cheliceral proximal incline in lateral view without ridge or small process above modified hairs but followed smoothly by first modified hair (as in Fig. 131); without stridulatory ridges (unlike some other specimens; see variation below); abdomen globose and high; gonopore with five epiandrous spigots.

PALPS. As in Figs 122-124; coxa unmodified, trochanter with short ventral projection, femur with distinct retrolateral process proximally, ventral membranous area proximally bordered on both sides by heavily sclerotized ridges, and small dorsal projection proximally; femur-patella hinges close together dorsally; patella very short; procursus with proximal dorsal process, with weakly developed ventral pocket, and distal dorsal notch on prolateral sclerotized margin; bulb with membranous embolus rising from base of process a; process a with subdistal hump; process $\mathrm{b}$ narrow, elongated, and pointed; process $\mathrm{c}$ triangular; process $d$ is a distinct small ventral projection (as in Figs 125, 127, 149).

LeGs. Without spines; with long curved hairs, especially on tibiae and metatarsi; retrolateral trichobothrium on tibia 1 at $10 \%$; prolateral trichobothrium present on all tibiae; pseudosegmentation not visible.

\section{Male (variation)}

Tibia 1 in 13 other males: 10.6-18.1 (mean 13.1); color pattern on abdomen varies from pale without any marks to light brown with lateral stripes; leg color varies from light brown to ochre; ocular area usually light brown; carapace pattern varies from wide brown lateral marks to pale carapace with median band only; two brown bands at base of ocular area sometimes absent; clypeus dark rim and dark band sometimes absent; procursus distal dorsal notch on prolateral margin sometimes slightly elevated and not a distinct indentation (Fig. 126); process c sometimes curved and pointing towards prolateral; lateral stridulatory ridges sometimes absent (as in specimen described above) or very indistinct but sometimes present (Figs 128, 131, 153); cheliceral proximal incline usually without ridge or small process above modified hairs in lateral view (Figs 131, 133); sometimes present but indistinct (Fig. 132). Epiandrous spigots were counted in five additional males and varied from 4 to 7 .

\section{Female}

In general similar to male; tibia 1 in 24 females: 7.0-12.8 (mean 10.8); stridulatory files laterally on chelicerae always present (Fig. 154); epigynal plate square-shaped (Figs 134-145, 150), consisting of two sclerotized lateral rectangular areas that are gently swollen posteriorly and depressed medially anteriorly, pale median area with long dark median sclerite, usually fused at posterior epigynal margin with lateral sclerotized plates, small median indentation in posterior rim; anterior epigynal projections oval, not prominent in lateral view. 

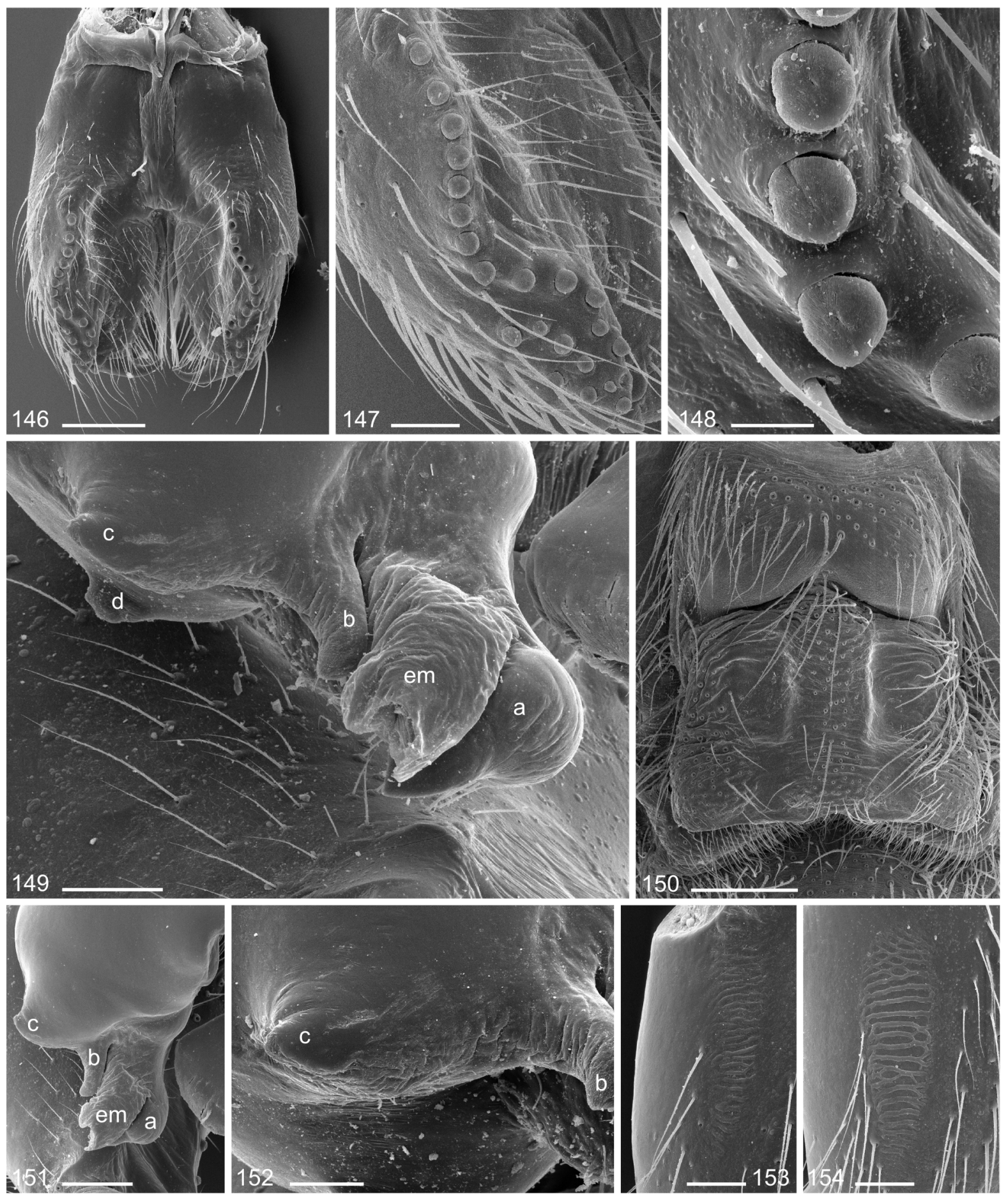

Figs 146-154. Artema transcaspica Spassky, 1934, ZMMU, Ak-Mechet (ð) and near Zarafshon (†). 146-148. Male chelicerae with frontal rows of modified (cone-shaped) hairs. 149. Male left bulbal processes. 150. Epigynal plate. 151. Male left bulbal processes. 152. Wrinkled area between processes $\mathrm{b}$ and $\mathrm{c}$ on male bulb. 153. Male stridulatory ridges. 154. Female stridulatory ridges. Scale lines: $146=$ $0.3 \mathrm{~mm} ; 147,149,153-154=0.1 \mathrm{~mm} ; 148=0.03 \mathrm{~mm} ; 150=0.4 \mathrm{~mm} ; 151=0.2 \mathrm{~mm} ; 152=0.06 \mathrm{~mm}$. 


\section{Distribution}

The species is distributed from the Kopet Dag Mountain Range in the south of Turkmenistan to Tajikistan in the East (Fig. 1). The species is also found north of this range and in Uzbekistan. It is likely that A. transcaspica occurs also in Kyrgystan and Kazakhstan. The single record from the United Arab Emirates is dubious (see below) and not shown in the map.

\section{Notes}

Artema transcaspica is very similar to A. doriae and to Artema sp. c from Pakistan, India, and Sudan (see below). While males of $A$. doriae and $A$. transcaspica are barely distinguishable, females differ slightly in their epigynum structure. For this reason, we decided to be conservative and not to synonymize A. doriae and A. transcaspica.

The single female from the United Arab Emirates is assigned tentatively because it does not seem to fit the distribution of this species.

Artema magna Roewer, 1960

Figs 1, 155-169

Artema magna Roewer, 1960: 43-45, figs 14a-h (+ , Afghanistan).

\section{Diagnosis}

The male specimen we tentatively assign to this species differs from all known congeners by the cheliceral armature: each male cheliceral process with unique median projection ending with two modified hairs (arrow in Fig. 164) that appear isolated and not linked (by further hairs) to main modified hairs ridge as in A. nephilit sp. nov. Female differs from all congeners by wide epigynal plate $(\sim 2.5 \times$ as wide as long $)$ and by distinctively protruding median posterior margin (Figs 168-169).

\section{Material examined}

\section{Holotype}

AFGHANISTAN: $q$ (together with 1 juv.), Konar valley, Qachgar cave, near Nurgal $\left[34.61^{\circ} \mathrm{N}\right.$, $70.76^{\circ}$ E], 6 Feb. 1958, K. Lindberg leg. (NHMG A 196).

\section{Other material}

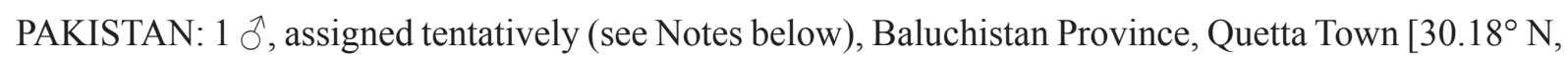
$66.99^{\circ}$ E], in building, 27 Jul. 2005, S.V. Ovchinnikov leg. (ZMMU).

\section{Description}

Male (Pakistan: Quetta; assigned tentatively)

MEASUREMENTS. Total body length 9.3, carapace width 4.3. Leg 1: $54.8(14.0+1.8+15.8+20.3+2.9)$, tibia 2: 11.8, tibia 3: 9.0, tibia 4: 12.0; tibia $1 \mathrm{~L} / \mathrm{d}$ : 39. Distance PME-PME $210 \mu \mathrm{m}$, diameter PME $230 \mu \mathrm{m}$, distance PME-ALE $100 \mu \mathrm{m}$, distance AME-AME $30 \mu \mathrm{m}$, diameter AME $210 \mu \mathrm{m}$.

Color. Carapace light ochre to beige with small brown spots laterally forming few small lines near median pit, with light brown median band that splits at posterior margin of ocular area to brown lines following base of ocular area and light brown band medially on ocular area; clypeus with wide ochre brown band below AME that fades towards dark brown edge of clypeus (as in Fig. 155); legs ochre to light brown with dark rings on femora subdistally, patellae + tibiae proximally, and tibiae subdistally, tips of femora and tibiae pale ochre; sternum ochre, with brown margins and median light brown dots forming cross-like pattern; abdomen beige without pattern. 
BoDy. Ocular area slightly elevated; carapace with median pit and distinct posterior furrow; clypeus unmodified; sternum wider than long (3.0/2.1); chelicerae as in Figs 162-164, with frontal row of $\sim 17$ modified (cone-shaped) hairs on each side with median projection ending with two modified hairs that appear isolated and not linked to main modified hairs ridge; without stridulatory ridges; Abdomen globose and high; gonopore with four epiandrous spigots.

PALPS. As in Figs 156-158; coxa unmodified; trochanter with short ventral projection; femur with short, somewhat pointed retrolateral process proximally; ventral large membranous area proximally bordered on both sides by sclerotized ridges; femur-patella hinges close together dorsally; patella very short; procursus with proximal dorsal process, with weakly developed ventral pocket, with three weak distal dorsal notches on prolateral margin (Fig. 160); bulb with membranous embolus rising from base of processes $a$ and $b$, process a slightly spiraling with pointed tip; process $b$ elongated and pointed, process c robust, strongly curved towards prolateral (Fig. 160), process d low rounded projection on ventral side of bulb (Fig. 159).

LEGS. Without spines; with long curved hairs, especially on tibiae and metatarsi; retrolateral trichobothrium on tibia 1 at $10 \%$; prolateral trichobothrium present on all tibiae; pseudosegmentation not visible.

\section{Female (holotype)}

In general similar to male; tibia 1: 17.8; abdomen beige with lateral gray stripes with large marks dorsally (Figs 165-166); stridulatory files laterally on chelicerae present; epigynum $\sim 2.5 \times$ wider than long, median posterior margin protruding (Figs 168-169); epigynal plate consisting of two swollen
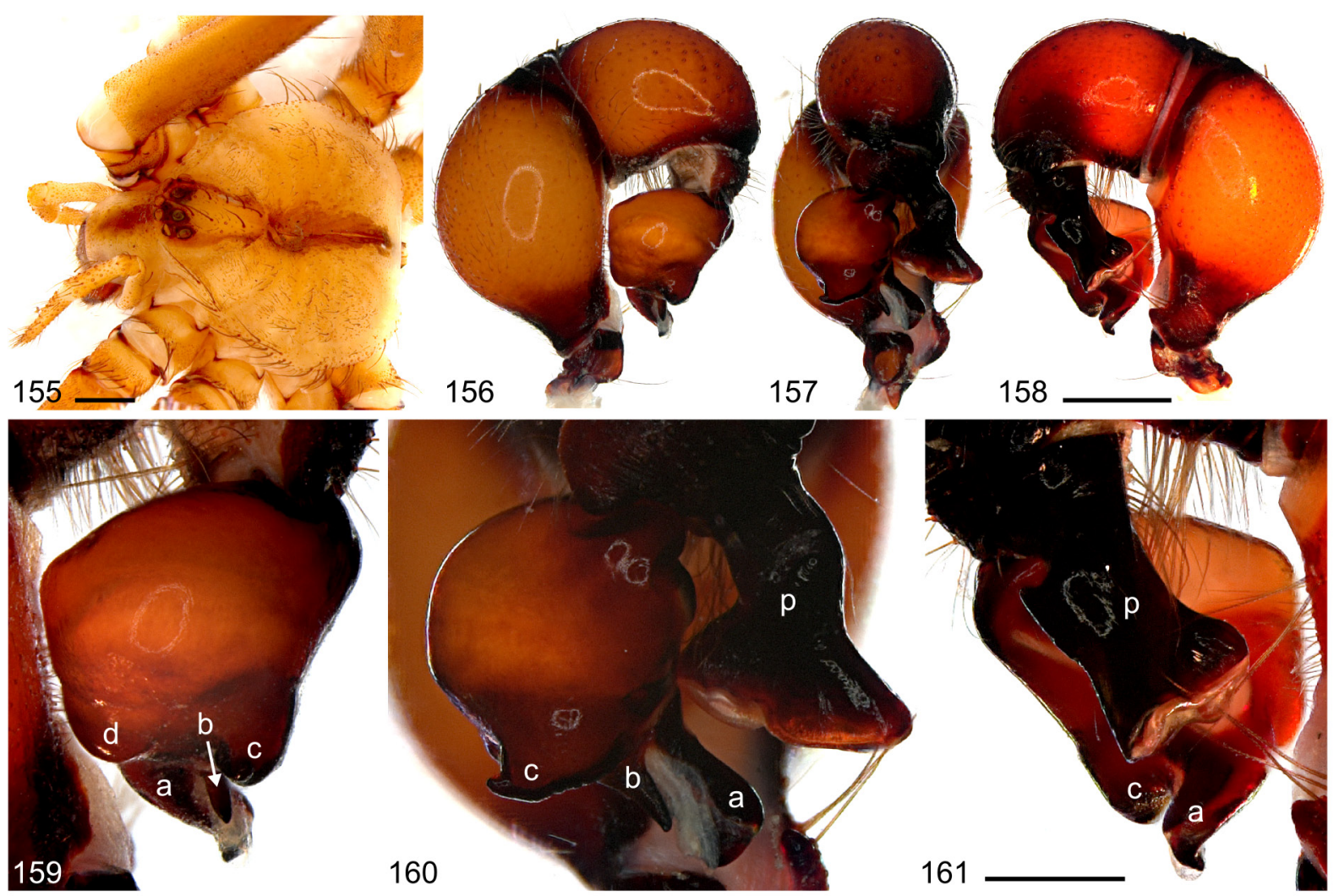

Figs 155-161. Artema magna Roewer, 1960. 155. Female prosoma (NHMG A 196, Afghanistan, Konar Valley). 156-158. Male left pedipalp (ZMMU, Pakistan, Baluchistan Province, Quetta): prolateral, dorsal, and retrolateral views. 159-161. Male left bulb and procursus: prolateral, dorsal, and retrolateral views. Scale lines: $155-158=1 \mathrm{~mm} ; 159-161=0.5 \mathrm{~mm}$. 
sclerotized lateral areas, pale median area, and dark median anterior sclerite; pair of projections anterior to epigynum (AEP) oval, not prominent; sternum with light brown dots forming cross-like pattern more distinct than in male.

\section{Natural history}

The female holotype was collected in a cave. The only known male was collected inside a house, together with a male of a different, unnamed species (see Artema sp. c below).

\section{Distribution}

If the male from Pakistan is correctly assigned to this species, then Artema magna may have a wide distribution along the mountain ridge from north-eastern Afghanistan to south-western Pakistan.
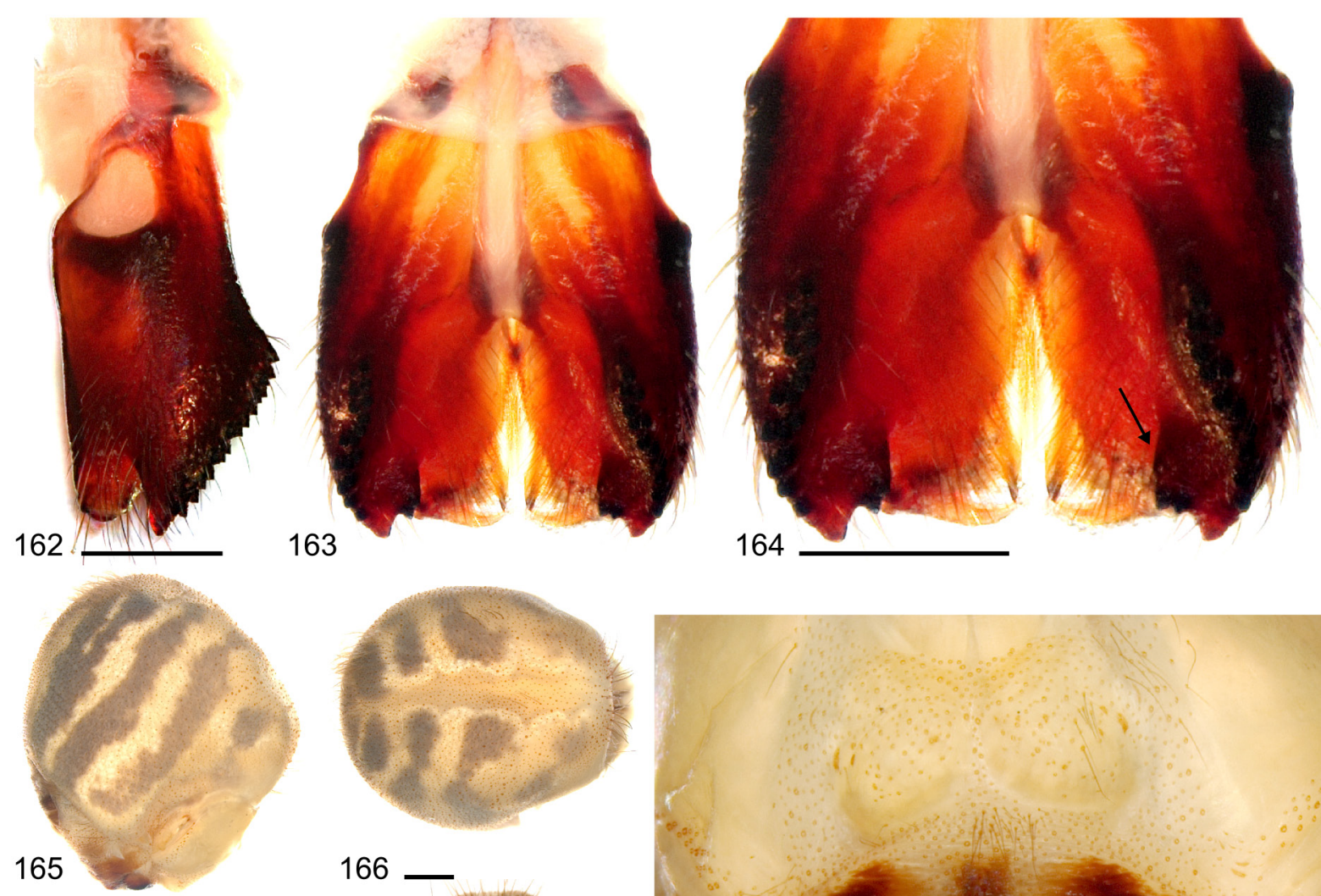

166

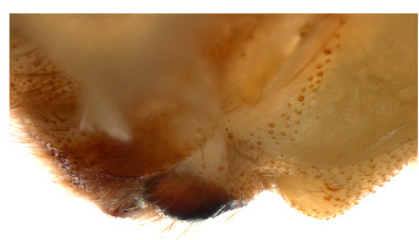

167

168

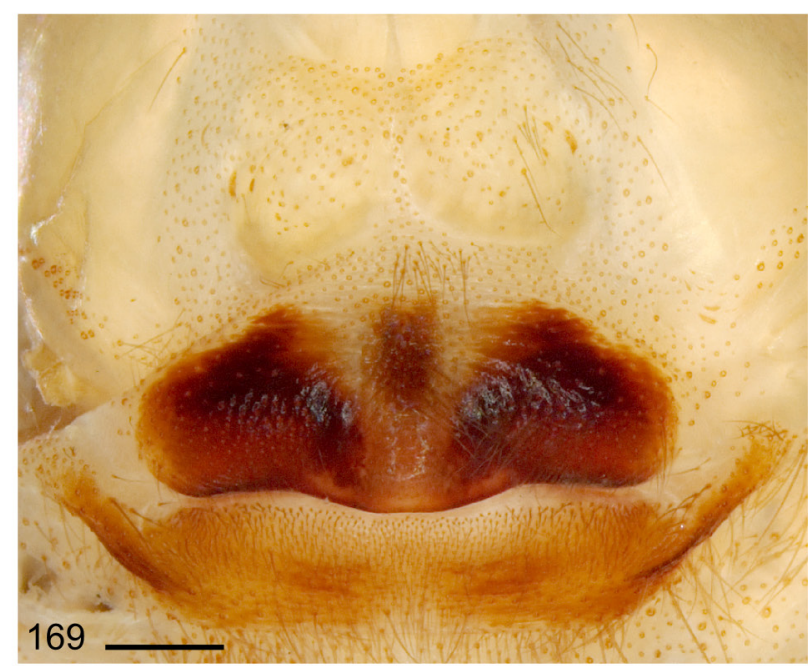

Figs 162-169. Artema magna Roewer, 1960. 162-164. Male chelicerae (ZMMU, Pakistan, Baluchistan Province, Quetta), lateral and frontal views (arrow: distinctive median projection). 165-166, 168. Female abdomen (NHMG A 196, Afghanistan, Konar Valley): lateral, dorsal, and ventral views. 167, 169. Epigynum and anterior epigynal projections (AEP): lateral and ventral views. Scale lines: $162-164,167,169=0.5 \mathrm{~mm} ; 165-166,168=1 \mathrm{~mm}$. 


\section{Notes}

We tentatively assign the male from Pakistan to A. magna mainly because both this male and the female holotype show some specific similarities to $A$. nephilit sp. nov. rather than to the geographically closer A. doriae and A. transcaspica. Males of A. magna and A. nephilit sp. nov. share the pair of inner projections on the cheliceral process and cheliceral lateral shape, while females have wider epigyna than A. doriae and A. transcaspica.

The dubious Artema ziaretana (Roewer, 1960) is based on a single juvenile specimen originating from near Jalalabad (located only $\sim 35 \mathrm{~km}$ from the type locality of $A$. magna) and may well be a synonym of A. magna.

\section{Undescribed putative species}

The following specimens are not formally described either because of small sample sizes (two putative species are represented by only one specimen each) or because of unclear species limits. Our aim here is to direct future collecting efforts while avoiding the potential taxonomic problems resulting from formal descriptions based on inadequate data. For more specific justifications see individual descriptions below. During the final editing of the manuscript we received further specimens from southern Iran (Fars Prov., Khonj, Khan Cave, $27.7^{\circ} \mathrm{N}, 53.3^{\circ} \mathrm{E}$, M.S. Tahami leg., in ZMSU) that seem to represent yet another species.

\section{Artema sp. a from Oman}

Fig. 170

\section{Material examined}

OMAN: 1 \% , Jebal Akhdar, E of Al Hamra, Wadi Fallah, Al Ghubrat $\left[23.1^{\circ}\right.$ N, 57.4 E], "Quellhöhle", Nov. 2001, Sattmann leg. (NHMW).

\section{Notes}

Female distinguished from all other Artema females by simple rectangular epigynum (Fig. 170). Stridulatory files laterally on chelicerae present. Epigynum almost twice as wide as long, posterior margin almost straight, epigynal plate consisting of two gently sclerotized lateral areas that appear swollen posteriorly, pale median area wider anteriorly, dark median sclerite absent. Pair of projections anterior to epigynum (AEP) present but not prominent.

Female genitalia in the genus Artema often show high intra-specific variation, e.g., as in A. nephilit sp. nov. (Figs 45-54) and in A. doriae (Figs 103-114), both of which occur close to Oman (Yemen and the United Arab Emirates). Therefore, we prefer not to describe this putative species formally until more individuals (females and males) are avilable.

Artema sp. b from Algeria

Figs 171-179

\section{Material examined}

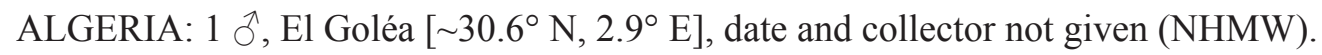

\section{Notes}

This male specimen resembles $A$. kochi for its lack of bulbal processes c, d, and e but, unlike $A$. kochi, bulbal process $b$ is pointed as in all other congeners and not flattened (Fig. 175). Cheliceral processes 
AHARON S. et al., Revision of the spider genus Artema (Araneae, Pholcidae)
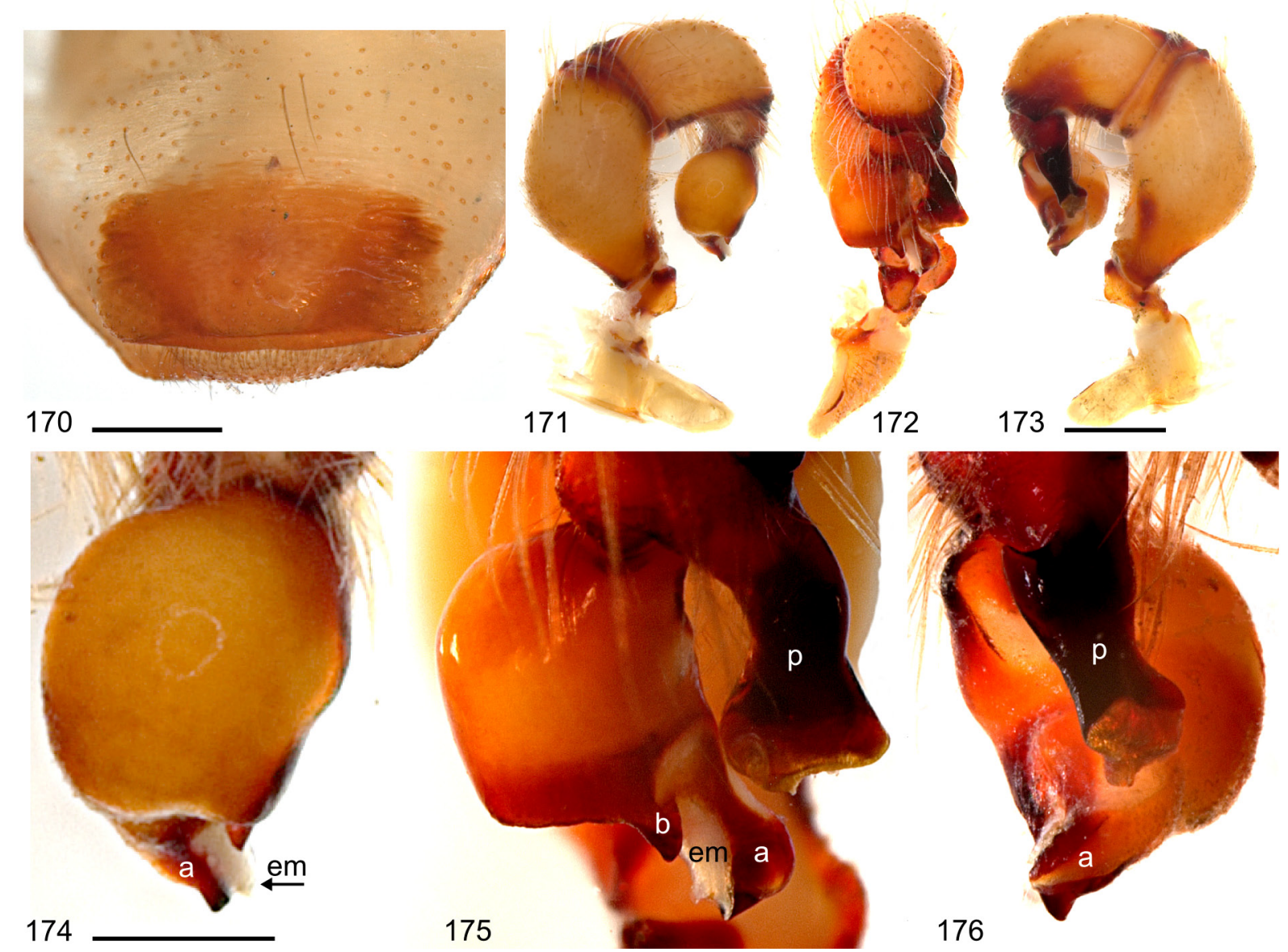

174
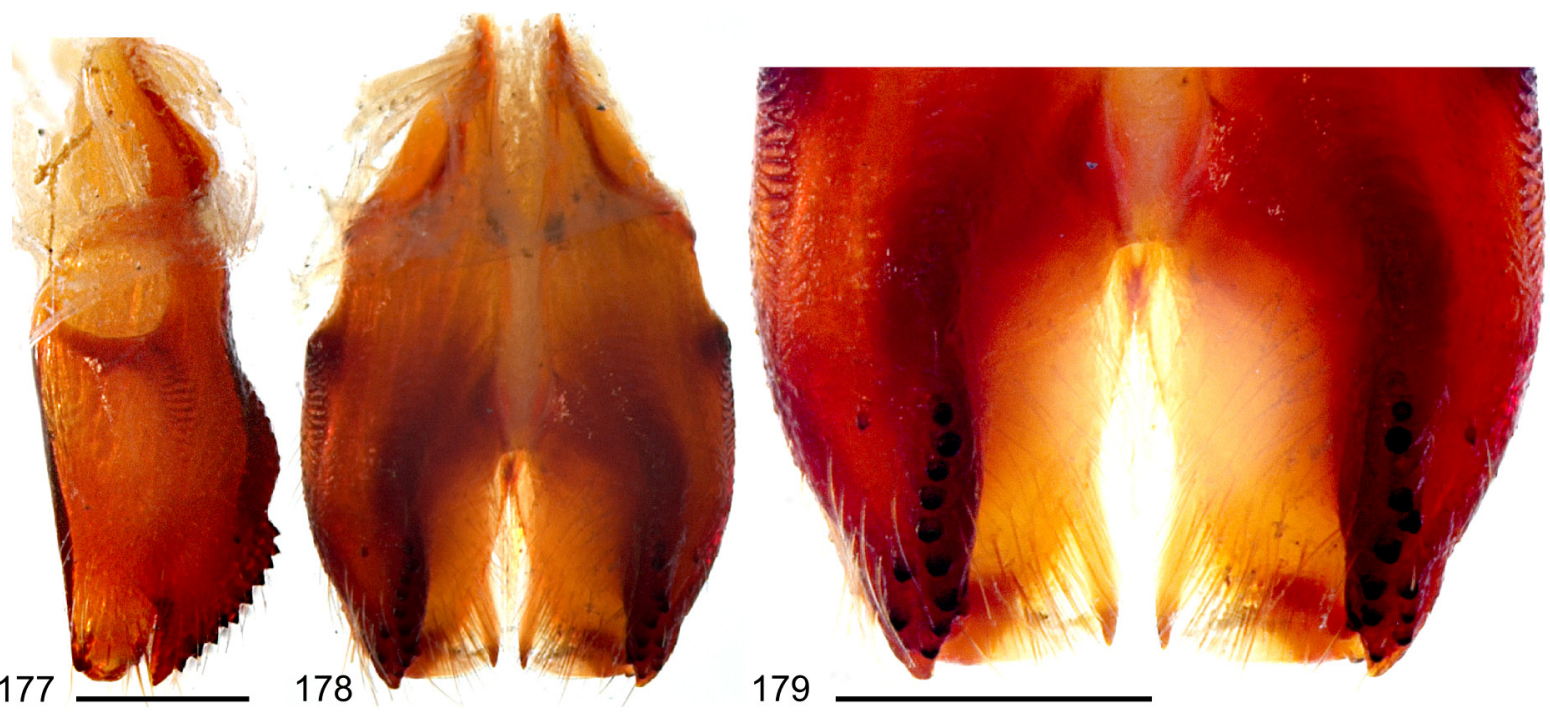

Figs 170-179. 170. Artema sp. a from Oman Jebal Akhdar, E of Al Hamra, Al Ghubrat (NHMW), epigynum, ventral view. 171-179. Artema sp. b from Algeria, El Goléa (NHMW). 171-173. Male left pedipalp: prolateral, dorsal, and retrolateral views. 174-176. Male left bulb and procursus: prolateral, dorsal, and retrolateral views. 177-179. Male chelicerae: lateral and frontal views. Scale lines: 170, $174-179=0.5 \mathrm{~mm} ; 171-173=1 \mathrm{~mm}$. 
with frontal row of about 12 modified hairs on each side, situated distally on chelicerae in "hook-like" arrangement (Fig. 179). Stridulatory files laterally on chelicerae present (Fig. 177).

Although the male palp appears distinctive, this single male specimen was the only Artema specimen available to us from North Africa that was not $A$. atlanta. It was probably collected long ago (date is not indicated) impeding molecular analysis. We suggest that more individuals (incl. females) should be available before the formal description of this putative species.

Artema sp. c from Sudan, Iran, Pakistan, and India

Figs 180-200, 207, 214

\section{Material examined}

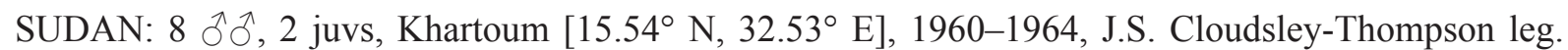
(MRAC 121706, 121718, 169130, 127506); 1 đ, in pure ethanol, Khartoum, 20 Aug. 2014, M. Siyam

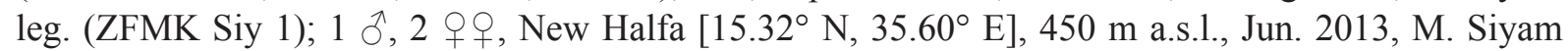
leg. (ZMB, 3 vials); 1 क, in pure ethanol, same locality, 10 Aug. 2014, in house, M. Siyam leg. (ZFMK Siy 2); 2 우, arrived in NY in engine parts from Sudan, Jun. 1995, K. Devage leg. (AMNH).

IRAN: 1 q, Fars Prov., Rafsanjan, Mirza Cave $\left(30.6^{\circ}\right.$ N, 56.3 ${ }^{\circ}$ E), 2300 m a.s.1., date not given, S.M. Tahami leg. (ZMSU); 1 o, Kerman Prov., Sirjan, Oota Cave (29.6 N, 55.1 ${ }^{\circ}$ E), $1880 \mathrm{~m}$ a.s.1., date not given, M.S. Tahami leg. (ZMSU).

PAKISTAN: 2 우, Baluchistan, Muslim Bagh Village $\left(30.783^{\circ}\right.$ N, $67.766^{\circ}$ E), 7 Sep. 2005 , S.V. Ovchinnikov leg. (ZMMU); 1 §, Baluchistan, Quetta Town $\left[30.18^{\circ} \mathrm{N}, 66.99^{\circ} \mathrm{E}\right]$, in house, 27 Jul. 2005, S.V. Ovchinnikov leg. (MMU).

INDIA: $1 \delta^{\lambda}$, in pure ethanol, Rajastan, Durjana $\left(29.00^{\circ} \mathrm{N}, 74.82^{\circ} \mathrm{E}\right), 181 \mathrm{~m}$, in steppe with sparse vegetation and single trees, at wall, 10 Mar. 2011, P. Jäger leg. (SMF); 1 o, Rajastan $\left[25.73^{\circ} \mathrm{N}\right.$, 73.34 E], 275 m, hill S Pali, 8 Jan. 1962, Ross and Cavagnaro leg. (CAS).

\section{Note}

These specimens are similar to A. doriae and to A. transcaspica, but females differ by a very inflated and prominent pale median area of the epigynal plate (arrow in Fig. 200); females also tend to have wider epigyna: $>1.6 \times$ as wide as long, versus $<1.6$ in $A$. doriae and A. transcaspica. Dark median sclerite varies from brown and long $(1.0 \times$ length of epigynal plate $)$ to very dark and short $(0.5 \times$ length of epigynal plate) to totally absent. Males differ from A. transcaspica (Figs 125-127) by deeper dorsal notch on distal margin of procursus and from A. doriae (Figs 94-96) by shapes of processes a and c. Males also with more distinct and robust ridge above modified hairs in lateral view (Figs 186-189, arrows in Figs 190-191). Preliminary molecular data (16S and CO1 sequences) indicate that specimens from India and Sudan are indeed conspecific (identical sequences in both genes), but clearly different from A. nephilit sp. nov., A. bunkpurugu, A. doriae, and A. atlanta: P-distances to these four species range from 12.8 to $19.0 \%$ for $\mathrm{CO} 1$ and 14.6 to $20.0 \%$ for $16 \mathrm{~S}$ (J. Eberle, A. Valdez-Mondragón, D. Dimitrov, B.A. Huber, unpublished data). However, as long as species limits between A. transcaspica and $A$. doriae are not convincingly solved, we feel that adding yet another name to this group potentially creates more problems than it solves.

\section{Discussion}

Even though this first revision of the genus Artema brings some order into the taxonomic chaos, we admit that several questions remain unanswered. As already noted by Simon (1893), the species are 
morphologically mostly very similar to each other. This conservative morphology, combined with some degree of intraspecific geographic and even individual variation, obscures species limits and requires dense sampling over the entire geographic range. Unfortunately, many of the countries with autochthonous Artema species have been or are politically unstable, meaning access to material has been a major constraint for this project.

Some species can now be reliably identified. Most importantly, we provide the means to distinguish the widespread type species $A$. atlanta from all other species. In the past, $A$. atlanta has caused considerable confusion, mirrored in the long list of synonyms, misidentifications, and erroneous synonymizations (as in the case of $A$. kochi). The fact that in some places A. atlanta occurs together with indigenous Artema species, highlights the importance of being able to distinguish this species from other congeners.

Of the other species, a group of three - found in Africa, the Arabian Peninsula, and the Levant - are easily distinguishable (A. kochi, A. bunkpurugu, and A. nephilit sp. nov.), while the other four species - found
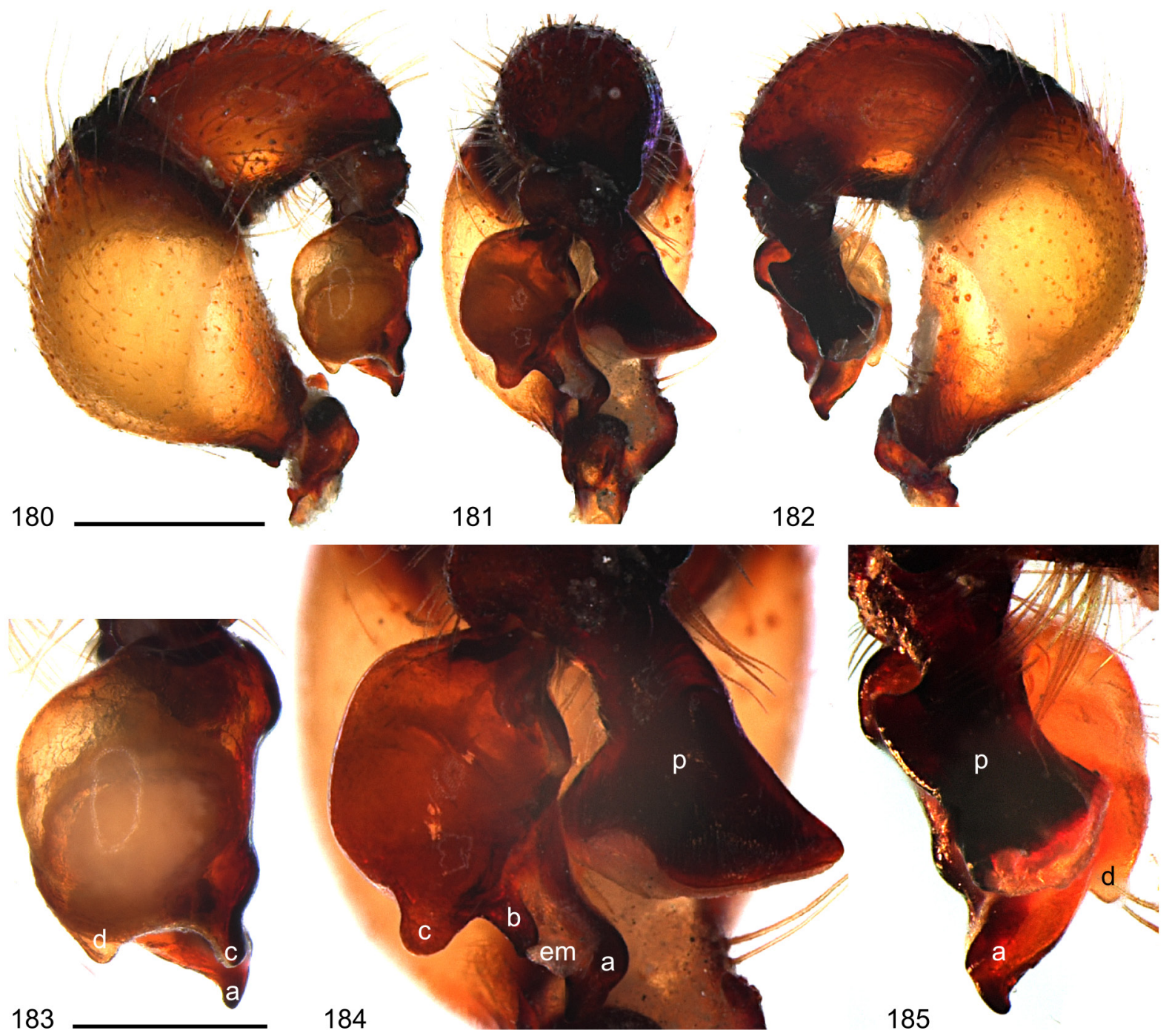

Figs 180-185. Artema sp. c from Pakistan, Baluchistan Province, Quetta (ZMMU). 180-182. Male left pedipalp: prolateral, dorsal, and retrolateral views. 183-185. Male left bulb and procursus: prolateral, dorsal, and retrolateral views. Scale lines: $180-182=1 \mathrm{~mm} ; 183-185=0.5 \mathrm{~mm}$. 

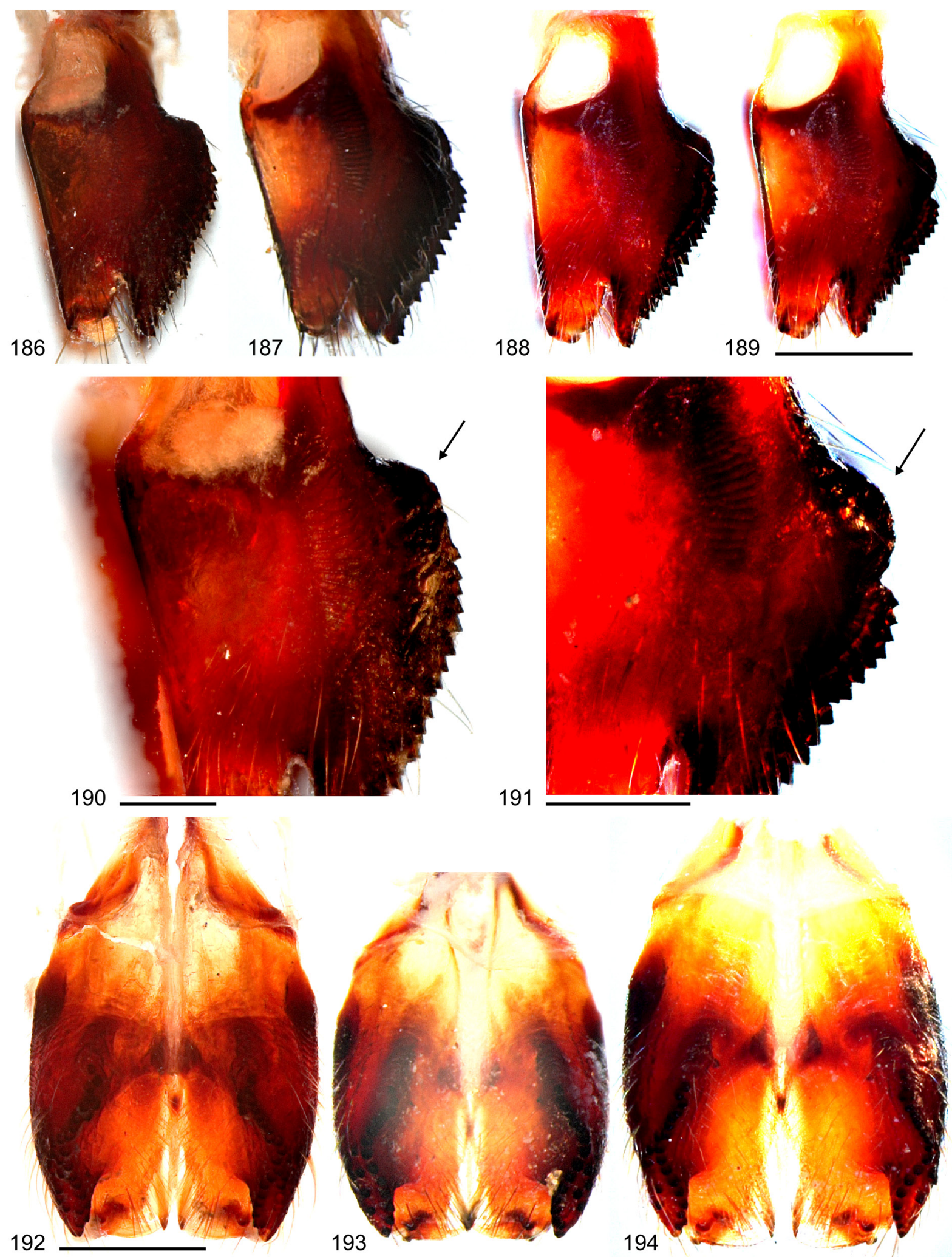

Figs 186-194. Artema sp. c, male chelicerae, lateral and frontal views. 186, 190, 192. Pakistan Baluchistan Province, Quetta (ZMMU). 187, 193. India Rajastan, Durjana (SMF). 188-189, 191, 194. Sudan, Khartoum (MRAC 121706). Arrows = robust projection proximally on frontal process. Scale lines: $186-189,192-194=0.5 \mathrm{~mm} ; 190=0.2 \mathrm{~mm} ; 191=0.25 \mathrm{~mm}$. 
in central and south Asia - all remain problematic in some respect. Artema doriae and A. transcaspica, even though represented in collections by fair numbers of specimens, are so similar to each other that an unambiguous separation seems impossible at this point. We suspect that Spassky (1934), when describing $A$. transcaspica, did not have any specimens of $A$. doriae available for comparison, but only the original description by Thorell (1881). Bearing in mind that this description was actually a footnote without any illustration, a comparison between the Caucasian and Iranian 'species' was simply impossible. We do not synonymize the two names because we actually found some minor differences, especially in females, but more material is needed to test the consistency of these differences.

Even more problematic are the two species of Roewer (1960) from Afghanistan, A. magna and A. ziaretana. The first because it is based on a single female specimen and we were not able to study any further material, except for a male from Pakistan that we only assume might be the same species. The latter, because it is based on a single juvenile specimen, and thus unidentifiable until new material becomes available from the type locality.

Finally, the material available to us suggests that a few further species might exist, especially in northern Africa (e.g., Algeria, Sudan), the Arabian Peninsula (e.g., Oman), the Middle East (e.g., Iran), and Pakistan/India (Rajasthan). The current study is thus just a first step that needs to be continued and complemented, in the first place by an intensive collecting effort.

\section{Acknowledgements}

This study was supported by the Israel Taxonomy Initiative (ITI) biodiversity survey grant, and ITI and Ben-Gurion University fellowships to SA. We thank the Steinhardt Museum of Natural History for support of BAH to visit Israel. We thank the Israel National Parks Authority for issuing the collection permits (2013/40027, 2013/40085 and 2014/40313). We thank N. Berner-Aharon for editorial help,
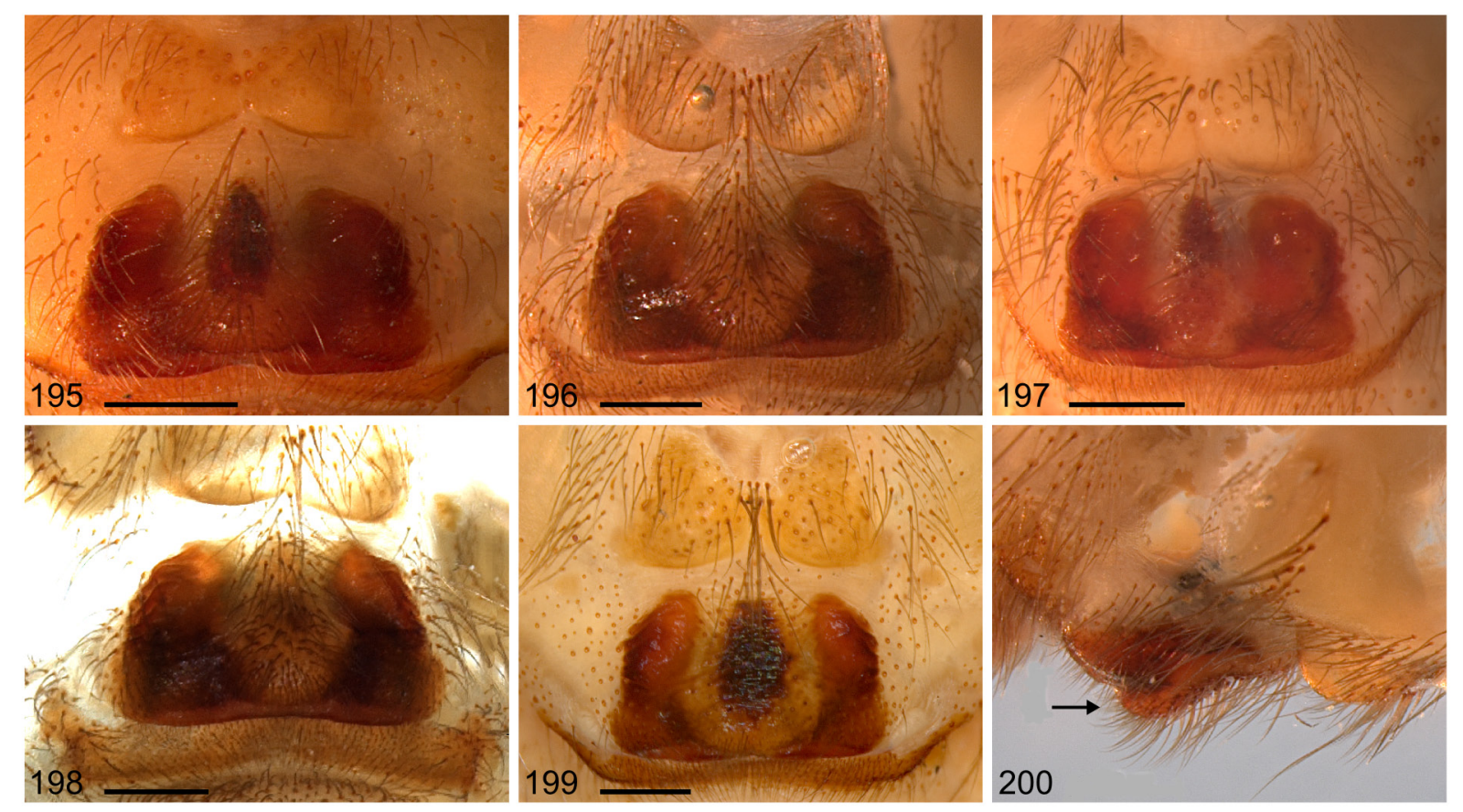

Figs 195-200. Artema sp. c, $q$, , epigyna, ventral (195-199) and lateral (200) views. 195. India, Rajastan, hill S Pali (CAS). 196-198, 200. Pakistan, Baluchistan, Muslim Bagh (ZMMU). 199. Sudan (AMNH). Scale lines: $0.5 \mathrm{~mm}$. 
Y. Lubin for supporting this study and for numerous discussions and useful comments, as well as R. Jocqué, L.S. Carvalho, and one anonymous reviewer for helpful comments on an earlier version of the manuscript. We thank the following curators and individuals for the loan of material: N. Platnick and L. Sorkin (AMNH), J. Beccaloni (NHMUK), C. Griswold (CAS), M. Hadjiconstantis (CMH), R. Bosmans (CRB), S. Zonstein (CSZ), D. Logunov (XUM, ZIN, ZMMU), M. Tavano (MSNG), L. Leibensperger (MCZ), P. Schwendinger (MHNG), C. Rollard (MNHN), R. Jocqué (MRAC), S. Whitman (MZUF), A. Hänggi (NHMB), C. Jonsson (NHMG), J. Gruber (NHMW), J. Altmann and P. Jäger (SMF), J. Dunlop (ZMB), M. Koch (ZMH), M. Tahami (ZMSU), and N. Scharff (ZMUC). Further material was gratefully received from C. Haddad, H. El-Hennawy, Y.M. Marusik, M. Siyam, A. van Harten, and A. Zamani. We thank B. Langford and E. Cohen from the Israel Cave Research Center, I. Armiach for assistance in the field, and H.J. Krammer for taking care of the live specimens. This is publication number 945 of the Mitrani Department of Desert Ecology.
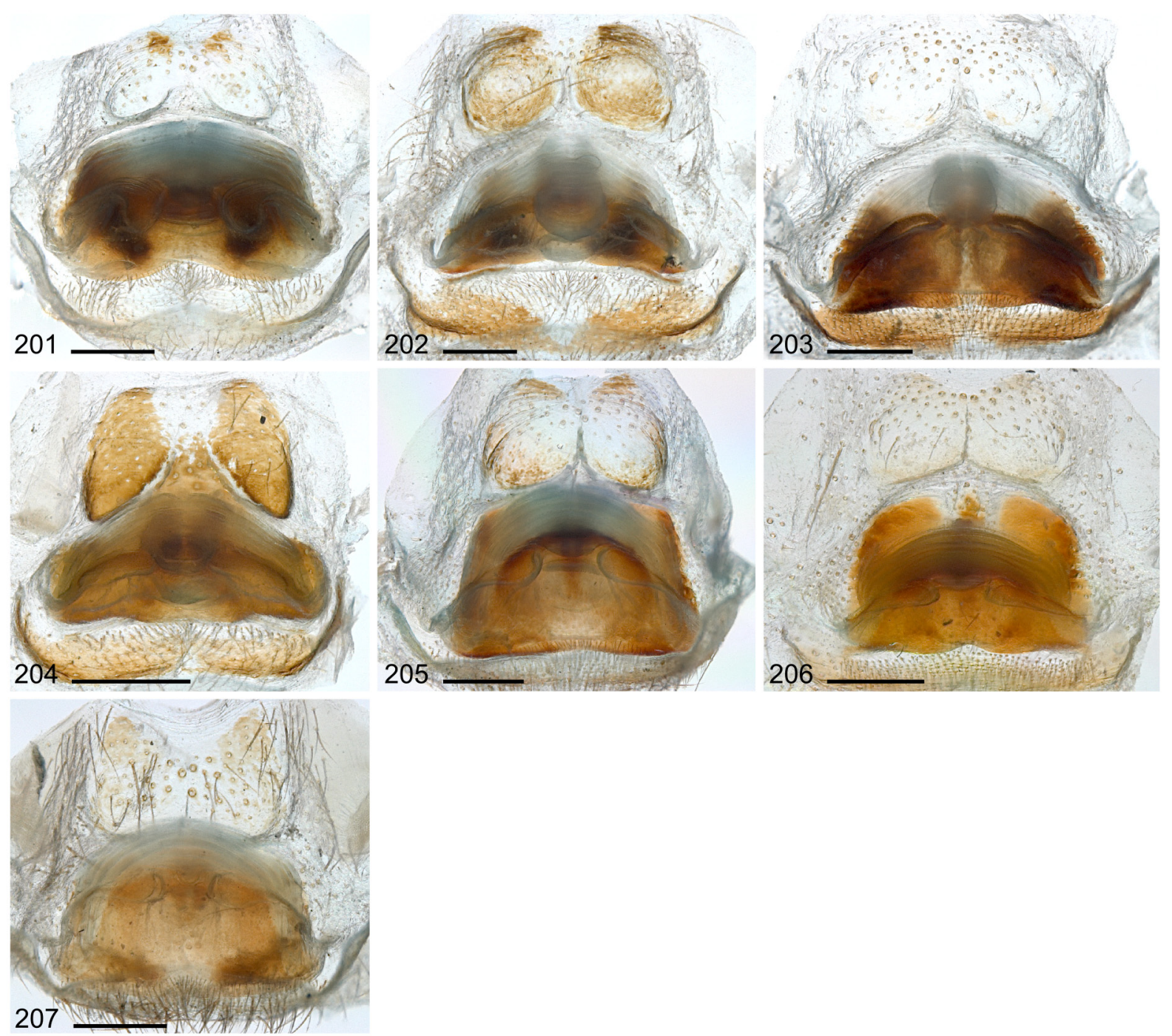

Figs 201-207. Cleared female genitalia, dorsal views. 201. Artema atlanta Walckenaer, 1837 (AMNH, USA, Arizona, Tucson). 202. A. bunkpurugu Huber \& Kwapong, 2013 (ZFMK Ar 10516, Ghana, Bunkpurugu-Nakpanduri). 203. A. nephilit sp. nov. (HUJ Ara 16020, Israel, Samar). 204. A. kochi Kulczyński, 1901 (MNHN AR 10169 part). 205. A. doriae Thorell, 1881 (ZFMK Ar 15234, Iran, Tehran Prov., Tochal). 206. A. transcaspica Spassky, 1934 (ZIN type vials). 207. Artema sp. c. (ZMMU, Pakistan, Baluchistan, Muslim Bagh). Scale lines: $0.5 \mathrm{~mm}$. 

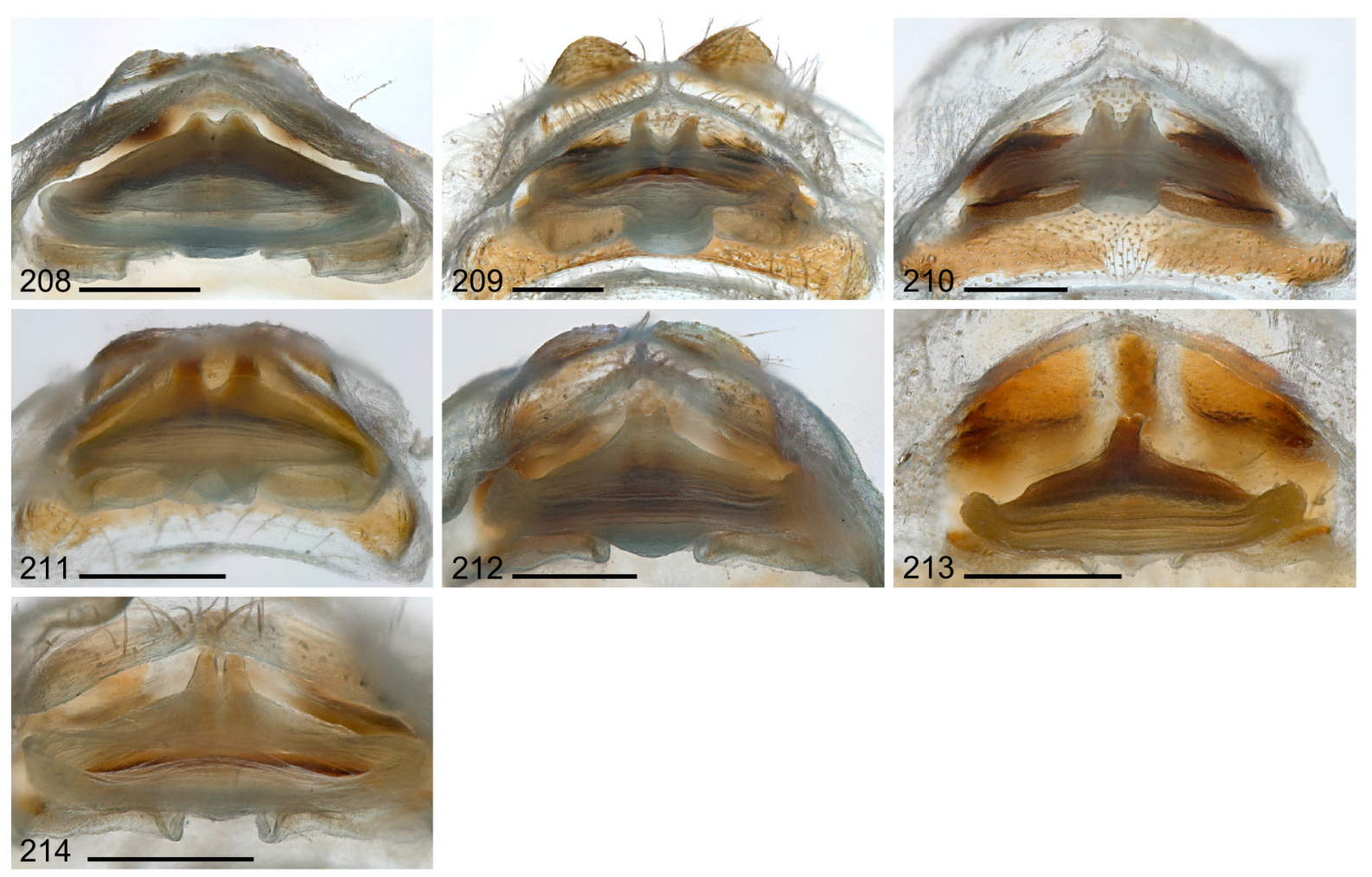

Figs 208-214. Cleared female genitalia, posterior dorsal views. 208. A. atlanta Walckenaer, 1837 (AMNH, USA, Arizona, Tucson). 209. A. bunkpurugu Huber \& Kwapong, 2013 (ZFMK Ar 10516, Ghana, Bunkpurugu-Nakpanduri). 210. A. nephilit sp. nov. (HUJ Ara 16020, Israel, Samar). 211. A. kochi Kulczyński, 1901 (MNHN AR 10169 part). 212. A. doriae Thorell, 1881 (ZFMK Ar 15234, Iran, Tehran Prov., Tochal). 213. A transcaspica Spassky, 1934 (ZIN type vials). 214. Artema sp. c (ZMMU, Pakistan, Baluchistan, Muslim Bagh). Scale lines: $0.5 \mathrm{~mm}$.

\section{References}

Aharon S. 2016. Ecology and Taxonomy of the Family Pholcidae in Israel: Species Richness, Geographic Distributions and Taxonomical Revision of the Genus Artema (Pholcidae, Araneae). MSc thesis, BenGurion University of the Negev, Israel. Available from

http://nnhc.huji.ac.i1/wp-content/uploads/2017/01/aharonshlomi.pdf [accessed 17 Oct. 2017].

Banks N. 1898. Arachnida from Baja California and other parts of Mexico. Proceedings of the California Academy of Sciences, 3rd series 1: 205-309.

Beatty J.A., Berry J.W. \& Huber B.A. 2008. The pholcid spiders of Micronesia and Polynesia (Araneae, Pholcidae). Journal of Arachnology 36: 1-25. https://doi.org/10.1636/H05-66.1

Blackwall J. 1858. Characters of a new genus and description of three recently discovered species of Araneida. Annals and Magazine of Natural History (3) 2: 331-335.

Blackwall J. 1866. A list of spiders captured in the southeast region of equatorial Africa, with descriptions of such species as appear to be new to arachnologists. Annals and Magazine of Natural History (3) 18: 451-468. 
Blackwall J. 1867. Descriptions of several species of East Indian spiders, apparently to be new or little known to arachnologists. Annals and Magazine of Natural History 19: 387-394.

Bodenheimer F.S. 1937. Prodromus fauna Palestinae. Mémoires de l'Institut d'Egypte 33. Institut d'Egypte, Cairo.

Bösenberg W. \& Lenz H. 1895. Ostafrikanische Spinnen, gesammelt von Herrn Dr. F. Stuhlmann in den Jahren 1888 und 1889. Jahrbuch der Hamburgischen Wissenschaftlichen Anstalten 12: 27-51.

Brignoli P.M. 1981. Studies on the Pholcidae, I. Notes on the genera Artema and Physocyclus (Araneae). Bulletin of the American Museum of Natural History 170: 90-100.

Brown B.V. 1993. A further chemical alternative to critical-point-drying for preparing small (or large) flies. Fly Times 11: 10.

Bryant E.B. 1940. Cuban spiders in the Museum of Comparative Zoology. Bulletin of the Museum of Comparative Zoology at Harvard College 86: 247-532.

Bryant E.B. 1948. The spiders of Hispaniola. Bulletin of the Museum of Comparative Zoology at Harvard College 100: 329-447.

Caporiacco L. di. 1928. Aracnidi di Giarabub e di Porto Bardia. Annali del Museo civico di storia naturale di Genova 53: 77-107.

Caporiacco L. di. 1936. Aracnidi Fezzanesi raccolti dal Prof. G. Scortecci nel 1934 - XII. Atti della Società italiana di scienze naturali e del Museo civico di storia naturale di Milano 75: 67-93.

Caporiacco L. di. 1948. Arachnida of British Guiana collected in 1931 and 1936 by Professors Beccari and Romiti. Proceedings of the Zoological Society of London 118: 607-747.

Caporiacco L. di. 1949. Aracnidi della Colonia del Kenya raccolti da Toschi e Meneghetti negli anni 1944-1946. Pontificia Academia Scientiarum, Commentationes 13: 309-492.

Chamberlin R.V. 1924. The spider fauna of the shores and islands of the Gulf of California. Proceedings of the California Academy of Sciences 7: 561-694.

Chrysanthus P. 1967. Spiders from south New Guinea IX. Tijdschrift voor Entomologie 110: 89-105.

Colmenares-García P.A. 2008. Tres nuevos registros para la araneofauna Venezolana (Arachnida, Araneae, Pholcidae). Boletín del Centro de Investigaciones Biológicas de la Universidad del Zulia 42: 85-92.

Dalmas R. de. 1920. Liste d'araignées de Boudron en Asie Mineure suivie d'une étude des espèces méditerranéennes du genre Habrocestum. Annali del Museo civico di storia naturale di Genova 50: 57-69.

Denis J. 1953. Araignées recueillies par P. Remy du Sud-Algérien au Hoggar. Bulletin de la Société zoologique de France 78: 311-324.

Denis J. 1958. Araignées (Araneidea) de 1‘Afghanistan. I. Videnskabelige Meddelelser fra Dansk Naturhistorisk Forening i Kjøbenhavn 120: 81-120.

Dimitrov D., Astrin J.J. \& Huber B.A. 2013. Pholcid spider molecular systematics revisited, with new insights into the biogeography and the evolution of the group. Cladistics 29: 132-146. https://doi.org/10.1111/j.1096-0031.2012.00419.x

Doleschall L. 1857. Bijdrage tot de kennis der Arachniden van den Indischen Archipel. Natuurkundig Tijdschrift voor Nederlandsch-Indie 13: 339-434.

Dyal S. 1935. Fauna of Lahore. 4.-Spiders of Lahore. Bulletin of the Department of Zoology of the Panjab University 1: 119-252. 
Feng Z. 1990. Spiders of China in Colour. Hunan Science and Technolgy Publishing House.

Franganillo B.P. 1926a. Arácnidos nuevos o poco conocidos de la Isla de Cuba. Boletín de la Sociedad Entomológica de España 9: 42-68.

Franganillo B.P. 1926b. Arácnidos de Cuba: Arácnidos nuevos o poco conocidos de la Isla de Cuba. El Siglo XX, Habana.

Franganillo B.P. 1936a. Los arácnidos de Cuba hasta 1936. Cultural, La Habana.

Franganillo B.P. 1936b. Arácnidos recogidos durante el verano de 1934. Estudios de "Belen" 1936 (57-58): 75-82.

Gao C.X. \& Li S.Q. 2010. Artema atlanta, a pantropical species new for China (Araneae, Pholcidae). Acta Arachnologica Sinica 19: 11-13.

Gertsch W.J. 1935. Spiders from the southwestern United States. American Museum Novitates 792: $1-31$.

Gertsch W.J. \& Davis L.I. 1942. Report on a collection of spiders from Mexico. IV. American Museum Novitates 1158: 1-19.

Ghahari H. \& Marusik Y.M. 2009. New data on spider fauna of Iran (Araneae). Turkish Journal of Arachnology 2: 1-8.

González-Sponga M.A. 2005. Arácnidos de Venezuela. Tres nuevos géneros y cuatro nuevas especies de la familia Pholcidae (Araneae). Saber, Universidad de Oriente 17: 99-109.

González-Sponga M.A. 2006. Arácnidos de Venezuela. Un nuevo género y cinco nuevas especies de la familia Pholcidae (Araneae). Sapiens, Revista Universitaria de Investigación 7: 9-27.

Huber B.A. 2000. New World pholcid spiders (Araneae: Pholcidae): a revision at generic level. Bulletin of the American Museum of Natural History 254: 1-348.

https://doi.org/10.1206/0003-0090(2000)254<0001:NWPSAP>2.0.CO;2

Huber B.A. 2001. The pholcids of Australia (Araneae; Pholcidae): taxonomy, biogeography, and relationships. Bulletin of the American Museum of Natural History 260: 1-144. https://doi.org/10.1206/0003-0090(2001)260\%3C0001:TPOAAP\%3E2.0.CO;2

Huber B.A. 2009. Four new generic and 14 new specific synonymies in Pholcidae, and transfer of Pholcoides Roewer to Filistatidae (Araneae). Zootaxa 1970: 64-68; Erratum, 1977: 68.

Huber B.A. 2011a. Revision and cladistic analysis of Pholcus and closely related taxa (Araneae, Pholcidae). Bonner zoologische Monographien 58: 1-509.

Huber B.A. 2011b. Phylogeny and classification of Pholcidae (Araneae): an update. Journal of Arachnology 39: 211-222. https://doi.org/10.1636/CA10-57.1

Huber B.A. 2016. Pholcidae: the longest legs in the web [online]. Available from http://www.pholcidae.de/ [accessed Nov. 2017].

Huber B.A. \& Eberhard W.G. 1997. Courtship, copulation, and genital mechanics in Physocyclus globosus (Araneae, Pholcidae). Canadian Journal of Zoology 74: 905-918. https://doi.org/10.1139/z97-109

Huber B.A. \& Fleckenstein N. 2008. Comb-hairs on the fourth tarsi in pholcid spiders (Araneae, Pholcidae). Journal of Arachnology 36: 232-240. https://doi.org/10.1636/CSh07-71.1

Huber B.A. \& Kwapong P. 2013. West African pholcid spiders: an overview, with descriptions of five new species (Araneae, Pholcidae). European Journal of Taxonomy 59: 1-44.

https://doi.org/10.5852/ejt.2013.59 
Huber B.A. \& Warui C.M. 2012. East African pholcid spiders: an overview, with descriptions of eight new species (Araneae, Pholcidae). European Journal of Taxonomy 29: 1-44.

https://doi.org/10.5852/ejt.2012.29

Huber B.A., Colmenares-García P.A. \& Ramirez M.J. 2014. Fourteen new generic and ten new specific synonymies in Pholcidae (Araneae), and transfer of Mystes Bristowe to Filistatidae. Zootaxa 3847 (3): 413-422. https://doi.org/10.11646/zootaxa.3847.3.5

ICZN (International Commission on Zoological Nomenclature) 1999. Article 31.1 International Code of Zoological Nomenclature, 4th edition. Adopted by the I.U.B.S. The International Trust for Zoological Nomenclature, London. Available from

http://www.nhm.ac.uk/hosted-sites/iczn/code/index.jsp?article=31\&nfv=true [accessed 15 Oct. 2017].

Irie T. 2009. Pholcidae. In: Ono H. (ed.) The Spiders of Japan with Keys to the Families and Genera and Illustrations of the Species: 106-111. Tokai University Press, Kanagawa.

Karsch F. 1879. Sieben neue Spinnen von Sta Martha. Entomologische Zeitschrift, Stettin 40: 106-109.

Karsch F. 1892. Arachniden von Ceylon und von Minikoy gesammelt von den Herren Doctoren P. und F. Sarasin. Berliner Entomologische Zeitschrift 36: 267-310.

Koch L. 1875. Aegyptische und abyssinische Arachniden gesammelt von Herrn C. Jickeli. Bauer and Raspe, Nürnberg.

Kulczyński W. 1901. Arachnoidea in Colonia Erythraea a Dre K. M. Levander collecta. Rozprawy $i$ Sprawozdania z Posiedzen Wydzialu Matematyczno Przyrodniczego Akademji Umiejetnosci, Krakow 41: 1-64.

Leardy Airaghi Z. 1902. Aracnidi di Mahé e Kandy. Atti della Società italiana di scienze naturali e del Museo civico di storia naturale di Milano 40: 345-373.

Lee P. 2005. An imported pholcid in Felixstowe. Newsletter of the British Arachnological Society 102: 7.

Lenz H. 1886. Beiträge zur Kenntnis der Spinnenfauna Madagascars. Zoologische Jahrbücher. Abteilung für Systematik, Geographie und Biologie der Tiere 1: 379-408.

Lenz H. 1891. Spinnen von Madagascar und Nossibé. Jahrbuch der Hamburgischen Wissenschaftlichen Anstalten 9: 161-182.

Lessert R. de. 1936. Araignées de l'Afrique orientale portugaise recueillies par MM. P. Lesne et H.-B. Cott. Revue suisse de zoologie 43: 207-306.

Majumder S.C. \& Biswas B. 1993. Taxonomic studies of some pholcid spiders from India (Araneae: Pholcidae). Records of the Zoological Survey of India 92: 1-3.

Malek Hosseini M.J., Zamani A. \& Sadeghi S. 2015. A survey of cave-dwelling spider fauna of Kohgiluyeh \& Boyer-Ahmad and Fars Provinces, Iran (Arachnida: Araneae). Revista Ibérica de Aracnología 27: 90-94.

Marpels B.J. 1955. Spiders from western Samoa. Journal of the Linnean Society of London, Zoology 42: 453-504.

Mello-Leitão C.F. de. 1918. Scytodidas e pholcidas do Brasil. Revista do Museu Paulista 10: 83-144.

Mello-Leitão C.F. de. 1941. Catálogo das aranhas da Colombia. Anais da Academia Brasileira de Ciencias 13 (4): 233-300.

Mello-Leitão C.F. de. 1942. Arañas del Chaco y Santiago del Estero. Revista del Museo La Plata (NS) 2: 381-426.

Mello-Leitão C.F. de. 1946. Arañas del Paraguay. Notas del Museo La Plata 11: 17-50. 
AHARON S. et al., Revision of the spider genus Artema (Araneae, Pholcidae)

Millot J. 1941. Les araignées de l'Afrique Occidentale Française - sicariides et pholcides. Mémoires de l'Académie des Sciences de l'Institut de France 64: 1-53.

Millot J. 1946. Les pholcides de Madagascar (Aranéides). Mémoires du Muséum national d'Histoire naturelle de Paris (N.S.) 22: 127-158.

Moenkhaus W.J. 1898. Contribuição para o conhecimento das aranhas de S. Paulo. Revista do Museu Paulista 3: 77-112.

Murphy F. \& Murphy J. 2000. An Introduction to the Spiders of South East Asia. Malaysian Nature Society, Kuala Lumpur.

Pérez González A. 1996. Sobre la ausencia del género Crossopriza (Araneae: Pholcidae) en Cuba, con una nueva sinonimia para Artema atlanta Walckenaer, 1837. Caribbean Journal of Science 32: 431-432.

Petrunkevitch A. 1911. A synonymic index-catalogue of spiders of North, Central and South America with all adjacent islands, Greenland, Bermuda, West Indies, Terra del Fuego, Galapagos, etc. Bulletin of the American Museum of Natural History 29: 1-791. https://doi.org/10.5962/bhl.title.23819

Petrunkevitch A. 1925. Arachnida from Panama. Transactions of the Connecticut Academy of Arts and Sciences 27: 51-248.

Petrunkevitch A. 1929. The spiders of Porto Rico. Part 1. Transactions of the Connecticut Academy of Arts and Sciences 30: 1-158.

Pickard-Cambridge F.O. 1902. Arachnida - Araneida and Opiliones. Biologia Centrali-Americana, Zoology 2: 313-424.

Pocock R.I. 1900. The Fauna of British India, including Ceylon and Burma. Arachnida. Springer, London.

Roewer C.F. 1955. Die Araneen der Österreichischen Iran-Expedition 1949/50. Sitzungsberichte der Österreichischen Akademie der Wissenschaften (1) 164: 751-782.

Roewer C.F. 1960. Solifugen und Opilioniden - Araneae Orthognathae, Haplogynae und Entelegynae (Contribution à l'étude de la faune d'Afghanistan 23). Göteborgs Kungliga Vetenskaps och Vitterhets Samhälles Handlingar 8 (7): 1-53.

Saaristo M.I. 1999. An arachnological excursion to the granitic Seychelles, 1-26th January 1999. Arachnid species lists for Silhouette, Cousine \& Mahé. Phelsuma 7 (Suppl. A): 1-12.

Saaristo M.I. 2001. Pholcid spiders of the granitic Seychelles (Araneae, Pholcidae). Phelsuma 9: 9-28.

Saaristo M.I. 2010. Araneae. In: Gerlach J. \& Marusik Y. (eds) Arachnida and Myriapoda of the Seychelles Islands: 8-306. Siri Scientific Press, Manchester.

Sherriffs W.R. 1919. A contribution to the study of South Indian arachnology. The Annals and Magazine of Natural History, 9th Series, 4 (22): 220-253. https://doi.org/10.1080/00222931908673888

Simon E. 1873. Aranéides nouveaux ou peu connus du midi de l'Europe (2ième mémoire). Société Royale des Sciences de Liège 5: 187-351.

Simon E. 1882. II. Étude sur les arachnides de l'Yemen méridional. In: Viaggio ad Assab nel Mar Rosso, dei signori G. Doria ed O. Beccari con il R. Aviso "Esploratore" dal 16 Novembre 1879 al 26 Febbraio 1880. Annali del Museo civico di storia naturale di Genova 18: 207-260.

Simon E. 1885. Matériaux pour servir à la faune arachnologique de l'Asie méridionale. I. Arachnides recueillis à Wagra-Karoor près Gundacul, district de Bellary par M.M. Chaper. II. Arachnides recueillis à Ramnad, district de Madura par M. l'abbé Fabre. Bulletin de la Société zoologique de France 10: 1-39. 
Simon E. 1887. Arachnides recueillis à Obock en 1886, par M. le Dr L. Faurot. Bulletin de le Société zoologique de France. 12: 452-455.

Simon E. 1890. Étude arachnologiques. 22e Mémoire. XXXIV. Etude sur les arachnides de 1'Yemen. Annales de la Société Entomologique de France (6) 10: 77-124.

Simon E. 1893. Histoire naturelle des araignées Vol. 1: 257-488. Roret, Paris. https://doi.org/10.5962/bhl.title.51973

Simon E. 1894. On the spiders of the Island of St. Vincent. II. Proceedings of the Zoological Society of London 1894: 519-526.

Simon E. 1908. Étude sur les arachnides recueillis par M. le Dr Klaptocz en Tripolitaine. Zoologische Jahrbücher, Abteilung für Systematik, Geographie und Biologie der Tiere 26: 419-438.

Spassky S.A. 1934. Araneae palaearcticae novae. Fam. Pholcidae. Bulletin du Muséum national d'Histoire naturelle de Paris. 6: 361-372.

Tabrizi S.S., Rad S.P. \& Hedayati Z. 2014. A faunistic study on the spiders of several metropolis parks in Tehran, Iran. Indian Journal of Arachnology 3 (2): 28-39.

Taczanowski L. 1874. Les aranéides de la Guyane française. Horae Societatis Entomologicae Rossicae 10: $56-115$.

Thorell T. 1881. Studi sui ragni Malesi e Papuani. III. Ragni dell'Austro Malesia e del Capo York, conservati nel Museo civico di storia naturale di Genova. Annali del Museo civico di storia naturale di Genova 17: 1-727.

Thorell T. 1895. Descriptive Catalogue of the Spiders of Burma. British Museum, London.

Thorell T. 1898. Secondo saggio sui ragni Birmani. II. Retitelariae et Orbitelariae. Annali del Museo civico di storia naturale di Genova 39: 271-378.

Tikader B.K. 1977. Studies on spider fauna of Andaman and Nicobar Islands, Indian Ocean. Records of the Zoological Survey of India 72: 153-212.

Tikader B.K. \& Biswas B. 1981. Spider fauna of Calcutta and vicinity: Part-I. Records of the Zoological Survey of India, Occasional Paper 30: 1-149.

Tullgren A. 1910. Araneae. In: Sjöstedt Y. (ed.) Wissenschaftliche Ergebnisse der Schwedischen zoologischen Expedition nach dem Kilimandjaro, dem Meru und den umgebenden Massaisteppen Deutsch-Ostafrikas 1905-1906 unter Leitung von Prof. Dr Yngve Sjöstedt 20: 85-172. P. Palmquists aktiebolag, Stockholm. https://doi.org/10.5962/bhl.title.1805

van Keer K. \& van Keer J. 2001. Ingeburgerde exotische trilspinnen (Araneae: Pholcidae) in de Antwerpse haven en enkele algemene bedenkingen bij spinnenmigratie. Nieuwsbrief van de Belgische Arachnologische Vereniging 16: 81-86.

Vinson A. 1863. Aranéides des îles de la Réunion, Maurice et Madagascar. Roret, Paris. https://doi.org/10.5962/bhl.title.125517

Walckenaer C.A. 1837. Histoire naturelle des insectes. Aptères. Librairie encyclopédique de Roret, Paris 1: 1-682. https://doi.org/10.5962/bhl.title.61095

World Spider Catalog 2017. World Spider Catalog [online]. Natural History Museum, Bern. Available from http://wsc.nmbe.ch, version 18.5 [accessed Nov. 2017].

Yaginuma T. 1970. The spider fauna of Japan (revised in 1970). Bulletin of the National Science Museum Tokyo 13: 639-701. 
Manuscript received: 17 November 2016

Manuscript accepted: 3 May 2017

Published on: 8 December 2017

Topic editor: Rudy Jocqué

Desk editor: Kristiaan Hoedemakers

Printed versions of all papers are also deposited in the libraries of the institutes that are members of the EJT consortium: Muséum national d'Histoire naturelle, Paris, France; Botanic Garden Meise, Belgium; Royal Museum for Central Africa, Tervuren, Belgium; Natural History Museum, London, United Kingdom; Royal Belgian Institute of Natural Sciences, Brussels, Belgium; Natural History Museum of Denmark, Copenhagen, Denmark; Naturalis Biodiversity Center, Leiden, the Netherlands; Museo Nacional de Ciencias Naturales-CSIC, Madrid, Spain; Real Jardín Botánico de Madrid CSIC, Spain. 